Prepared in cooperation with the Bureau of Reclamation and the Colorado River Basin Salinity Control Forum

\title{
Hydrosalinity Studies of the Virgin River, Dixie Hot Springs, and Littlefield Springs, Utah, Arizona, and Nevada
}

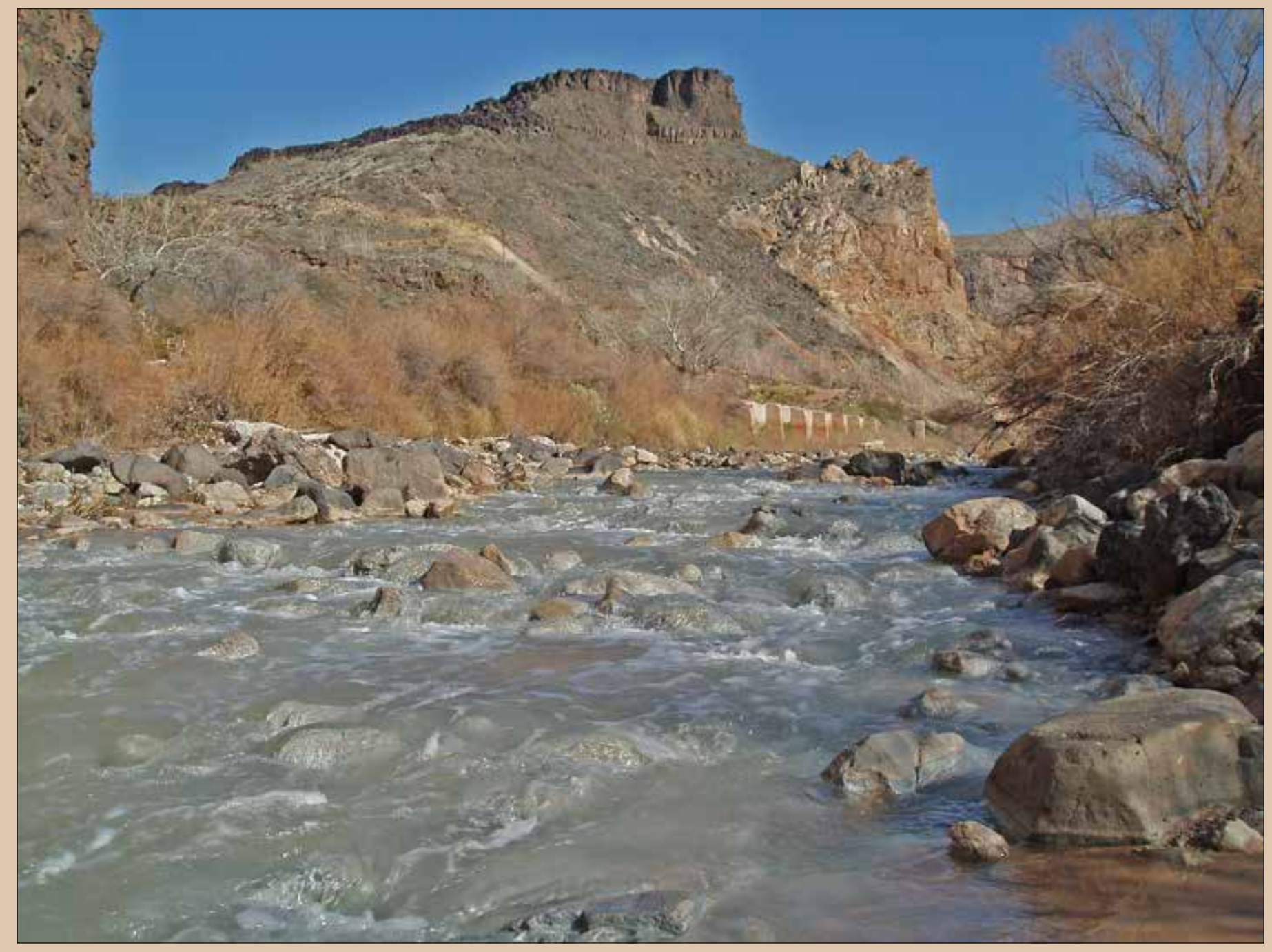

Scientific Investigations Report 2014-5093 
Cover photograph: Mouth of Timpoweap Canyon, Virgin River, near LaVerkin, Utah, looking east upstream, February 2010. Photograph by Steven Gerner. 


\section{Hydrosalinity Studies of the Virgin River, Dixie Hot Springs, and Littlefield Springs, Utah, Arizona, and Nevada}

Edited by Steven J. Gerner and Susan A. Thiros

Prepared in cooperation with the Bureau of Reclamation and the

Colorado River Basin Salinity Control Forum

Scientific Investigations Report 2014-5093 


\title{
U.S. Department of the Interior SALLY JEWELL, Secretary
}

\section{U.S. Geological Survey Suzette M. Kimball, Acting Director}

\author{
U.S. Geological Survey, Reston, Virginia: 2014
}

For more information on the USGS - the Federal source for science about the Earth, its natural and living resources, natural hazards, and the environment, visit http://www.usgs.gov or call 1-888-ASK-USGS.

For an overview of USGS information products, including maps, imagery, and publications, visit http://WwW.usgs.gov/pubprod

To order this and other USGS information products, visit http://store.usgs.gov

Any use of trade, firm, or product names is for descriptive purposes only and does not imply endorsement by the U.S. Government.

Although this information product, for the most part, is in the public domain, it also may contain copyrighted materials as noted in the text. Permission to reproduce copyrighted items must be secured from the copyright owner.

Suggested citation:

Gerner, S.J., and Thiros, S.A., eds., 2014, Hydrosalinity studies of the Virgin River, Dixie Hot Springs, and Littlefield Springs, Utah, Arizona, and Nevada: U.S. Geological Survey Scientific Investigations Report 2014-5093, 47 p. http://dx.doi.org/10.3133/sir20145093.

ISSN 2328-0328 (online) 


\section{Contents}

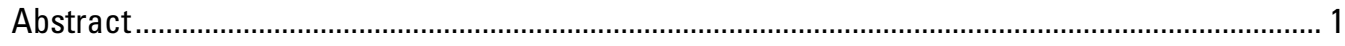

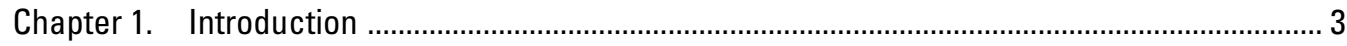

Overview of Dissolved-Solids Sources to the Virgin River ................................................... 3

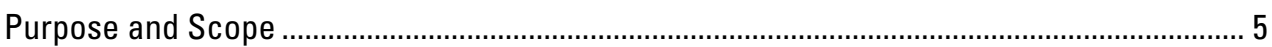

Water-Quality and Discharge Data Collected for this Study .............................................. 6

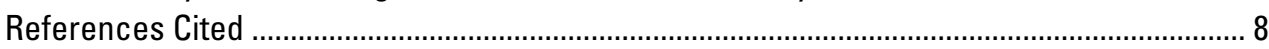

Chapter 2. Discharge and Dissolved-Solids Load Contributed by Dixie Hot Springs to the

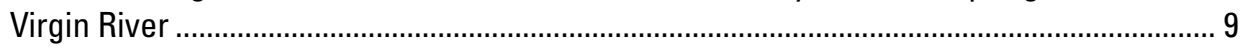

Discharge Determined from Area-Velocity Measurements .................................................. 10

Discharge Determined from Stage-Discharge Relation ...................................................... 10

Discharge Determined from Tracer-Injection Methods ...................................................... 13

Slug Tracer-Injection Method................................................................................. 13

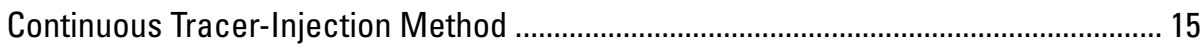

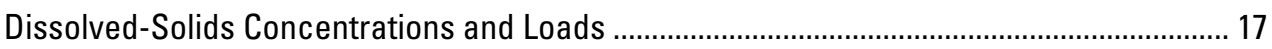

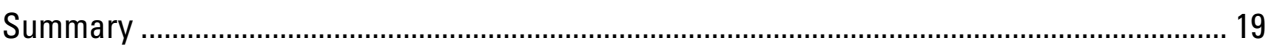

References Cited ................................................................................................................ 20

Chapter 3. Dissolved-Solids Loads Estimated at Selected Sites in the Virgin River Basin ........ 21

Methods of Estimating Dissolved-Solids Loads .................................................................. 22



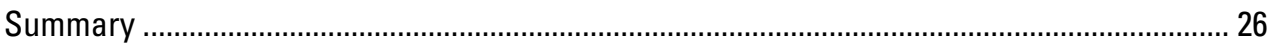

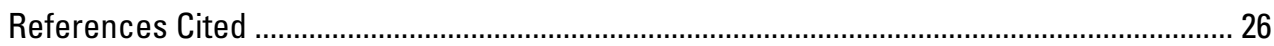

Chapter 4. Streamflow Losses in the Virgin River Between Bloomington, Utah, and the

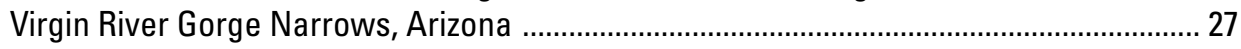

Streamflow Losses Determined from Monthly Streamflow Data .......................................... 27

Streamflow Losses Determined from Synoptic Discharge Measurements .......................... 29

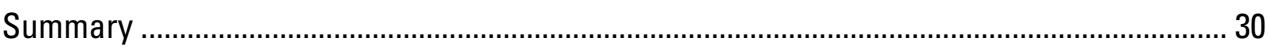

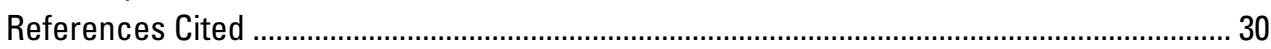

Chapter 5. Sources of Groundwater Discharge from Littlefield Springs in and near the

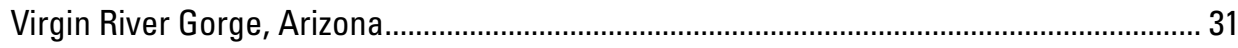

Sources of Groundwater Discharge from Littlefield Springs .............................................. 31

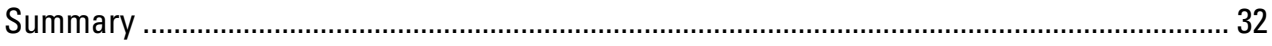

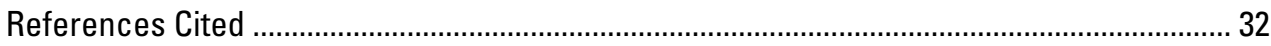

Chapter 6. Hypothetical Changes to Dissolved-Solids Concentrations and Loads in Discharge from Irrigated Lands Following the Reduction of Dissolved-Solids Loads from Dixie Hot Springs to the Virgin River ............................................................. 33

Changes in Dissolved Solids in Virgin River Water Used for Irrigation .................................. 33

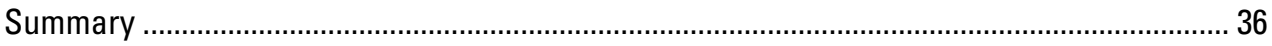

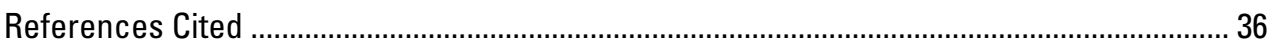

Chapter 7. Hypothetical Dissolved-Solids Loads in the Virgin River Following the Reduction of Dissolved Solids in Discharge from Dixie Hot Springs .................................. 37

Estimates, Calculations, and Assumptions Used in the Mass-Balance Model ...................... 37

Dissolved-Solids Loads Estimated by the Mass-Balance Model .......................................... 41

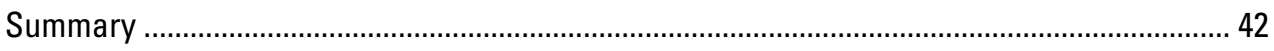



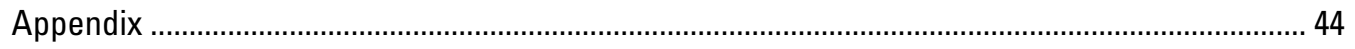




\section{Figures}

1. Map showing geographic features and selected monitoring sites in the Virgin River Basin, Utah, Arizona, and Nevada

2. Map showing geographic features and selected discharge points from Dixie Hot Springs, and monitoring sites on the Virgin River near Dixie Hot Springs, Utah

3. Graphs showing relation of stage to discharge in the Virgin River at $A$, above Dixie Hot Springs and $B$, below Dixie Hot Springs, Utah

4. Graph showing discharge determined from the stage-discharge relation in the Virgin River upstream and downstream of Dixie Hot Springs, Utah, and from

Dixie Hot Springs on February 16-18, 2010

5. Schematic diagram showing the slug tracer-injection method of measuring discharge

6. Graphs showing variation in bromide concentration over time at sites VR-2 and VR-3 on the Virgin River, Utah, during slug tracer-injection tests on February 17, 2010 16

7. Graph showing variation in bromide concentration over time at selected sites on the Virgin River, Utah, during a continuous tracer-injection test on February 17, 2010 16

8. Graph showing relation of dissolved-solids concentration to specific conductance in the Virgin River at sites VR-2 and VR-3 of Dixie Hot Springs, Utah

9. Bar graph showing average annual dissolved-solids load at selected sites in the Virgin River Basin, water years 2007-10

10. Map showing stream-gaging stations, sites near faults where synoptic discharge measurements were made to determine seepage losses from the Virgin River in August 2010, and sampled groundwater sites in and near the Virgin River Gorge, Utah and Arizona

11. Scatterplot showing monthly streamflow loss or gain in the Virgin River between sites VR-7 and VR-8 and between sites VR-8 and VR-14

12. Diagram showing composition of selected water samples representing irrigation inflow to agricultural areas near St. George and Washington, Utah, and discharge from sources downgradient of the agricultural areas

13. Diagram showing conceptual model illustrating the average annual discharge and dissolved-solids load at selected sites on the Virgin River for water years 1999-2001, 2003-04, and 2006-10, and intermediate gains or losses of discharge and dissolved-solids load 


\section{Tables}

1. Monitoring sites in the Virgin River Basin with water-quality or discharge data presented in this report

2. Selected measurements of discharge, specific conductance, and dissolvedsolids concentrations and loads, Dixie Hot Springs, Utah, 1960-2010

3. Field measurements and selected chemical constituents dissolved in surface water from the Virgin River near Dixie Hot Springs, Utah, and in groundwater discharging from Dixie Hot Springs, 2009-10

4. Discharge and dissolved-solids concentration and load in the Virgin River above and below Dixie Hot Springs, Utah, and calculated discharge and dissolvedsolids concentration and load from Dixie Hot Springs, 2009-10 .

5. Specific conductance of groundwater from selected discharge points for Dixie Hot Springs, Utah, on February 17, 2010

6. Summary of available dissolved-solids load calibration data at U.S. Geological Survey stream-gaging stations in the Virgin River Basin for water years 1992 through 2010, and Load Estimator (LOADEST) model descriptive statistics

7. Annual dissolved-solids loads estimated at 12 U.S. Geological Survey streamgaging stations and reported for the St. George Regional Water Reclamation Facility, Virgin River Basin, and annual daily mean streamflow

8. Synoptic discharge measurements used to determine streamflow losses in the Virgin River in and near the Virgin River Gorge, August 2010

9. Chemical analysis of samples from the Virgin River, Quail Creek Reservoir, groundwater, and selected agricultural drains near St. George and Washington, Utah

10. Net change in dissolved constituent concentrations between water applied to irrigated fields and water sampled from an agricultural drain near St. George and Washington, Utah

11. Potential minerals dissolved from soils in agricultural areas near St. George and Washington, Utah, and the change in mineral concentration between water diverted to agricultural areas and water discharging from those areas

12. Average annual discharge, dissolved-solids concentration, and dissolved-solids load at selected sites and reaches in the Virgin River and its tributaries for the period that includes water years 1999-2001, 2003-04, and 2006-10, estimated for a scenario that assumes a total seepage loss of 33.4 cubic feet per second from the Virgin River in and near the Virgin River Gorge

13. Average annual discharge, dissolved-solids concentration, and dissolved-solids load at selected sites and reaches in the Virgin River and its tributaries for the period that includes water years 1999-2001, 2003-04, and 2006-10, estimated for a scenario that assumes a total seepage loss of 26.7 cubic feet per second from the Virgin River in and near the Virgin River Gorge

Appendix 1. Annual mean streamflow and dissolved-solids load at selected sites in the Virgin River Basin 


\section{Conversion Factors, Datums, and Water-Quality Units}

Inch/Pound to SI

\begin{tabular}{|c|c|c|}
\hline Multiply & By & To obtain \\
\hline \multicolumn{3}{|c|}{ Length } \\
\hline foot (ft) & 0.3048 & meter $(\mathrm{m})$ \\
\hline mile (mi) & 1.609 & kilometer $(\mathrm{km})$ \\
\hline \multicolumn{3}{|c|}{ Volume } \\
\hline cubic foot $\left(\mathrm{ft}^{3}\right)$ & 0.02832 & cubic meter $\left(\mathrm{m}^{3}\right)$ \\
\hline acre-foot (acre-ft) & 1,233 & cubic meter $\left(\mathrm{m}^{3}\right)$ \\
\hline \multicolumn{3}{|c|}{ Flow rate } \\
\hline acre-foot per day (acre-ft/d) & 0.01427 & cubic meter per second $\left(\mathrm{m}^{3} / \mathrm{s}\right)$ \\
\hline acre-foot per year (acre-ft/yr) & 1,233 & cubic meter per year (m³/yr) \\
\hline cubic foot per second $\left(\mathrm{ft}^{3} / \mathrm{s}\right)$ & 0.02832 & cubic meter per second $\left(\mathrm{m}^{3} / \mathrm{s}\right)$ \\
\hline \multicolumn{3}{|c|}{ Mass } \\
\hline ton per day (ton/d) & 0.9072 & metric ton per year (mton/y) \\
\hline
\end{tabular}

Temperature in degrees Celsius $\left({ }^{\circ} \mathrm{C}\right)$ may be converted to degrees Fahrenheit $\left({ }^{\circ} \mathrm{F}\right)$ as follows:

${ }^{\circ} \mathrm{F}=\left(1.8 x^{\circ} \mathrm{C}\right)+32$

Vertical coordinate information is referenced to the North American Vertical Datum of 1988 (NAVD 88).

Horizontal coordinate information is referenced to the North American Datum of 1983 (NAD 83).

Specific conductance is given in microsiemens per centimeter at 25 degrees Celsius $(\mu \mathrm{S} / \mathrm{cm}$ at $\left.25^{\circ} \mathrm{C}\right)$.

Concentrations of chemical constituents in water are given either in milligrams per liter (mg/L) or micrograms per liter $(\mu \mathrm{g} / \mathrm{L})$.

\section{Abbreviations}

$\begin{array}{ll}\text { BCM } & \text { Basin Characterization Model } \\ \text { CFC } & \text { Chlorofluorocarbon } \\ \text { NWIS } & \text { National Water Information System } \\ \text { SGWC } & \text { St. George and Washington Canal } \\ \text { SGWRF } & \text { St. George Regional Water Reclamation Facility } \\ \text { STORET } & \text { U.S. Environmental Protection Agency Storage and Retrieval Data Warehouse } \\ \text { UDEO } & \text { Utah Department of Environmental Quality } \\ \text { USGS } & \text { U.S. Geological Survey } \\ \text { WY } & \text { Water year }\end{array}$




\title{
Hydrosalinity Studies of the Virgin River, Dixie Hot Springs, and Littlefield Springs, Utah, Arizona, and Nevada
}

\author{
Edited by Steven J. Gerner and Susan A. Thiros
}

\section{Abstract}

The Virgin River contributes a substantial amount of dissolved solids (salt) to the Colorado River at Lake Mead in the lower Colorado River Basin. Degradation of Colorado River water by the addition of dissolved solids from the Virgin River affects the suitability of the water for municipal, industrial, and agricultural use within the basin. Dixie Hot Springs in Utah are a major localized source of dissolved solids discharging to the Virgin River. The average measured discharge from Dixie Hot Springs during 2009-10 was 11.0 cubic feet per second $\left(\mathrm{ft}^{3} / \mathrm{s}\right)$, and the average dissolved-solids concentration was 9,220 milligrams per liter $(\mathrm{mg} / \mathrm{L})$. The average dissolvedsolids load - a measurement that describes the mass of salt that is transported per unit of time - from Dixie Hot Springs during this period was 96,200 tons per year (ton/yr).

Annual dissolved-solids loads were estimated at 13 monitoring sites in the Virgin River Basin from streamflow data and discrete measurements of dissolved-solids concentrations and (or) specific conductance. Eight of the sites had the data needed to estimate annual dissolved-solids loads for water years (WYs) 1999 through 2010. During 1999-2010, the smallest dissolved-solids loads in the Virgin River were upstream of Dixie Hot Springs (59,900 ton/yr, on average) and the largest loads were downstream of Littlefield Springs (298,200 ton/yr, on average). Annual dissolved-solids loads were smallest during 2002-03, which was a period of below normal precipitation. Annual dissolved-solids loads were largest during 2005 - a year that included a winter rain storm that resulted in flooding throughout much of the Virgin River Basin.

An average seepage loss of $26.7 \mathrm{ft}^{3} / \mathrm{s}$ was calculated from analysis of monthly average streamflow from July 1998 to September 2010 in the Virgin River for the reach that extends from just upstream of the Utah/Arizona State line to just above the Virgin River Gorge Narrows. Seepage losses from three river reaches in the Virgin River Gorge containing known fault zones accounted for about 48 percent of this total seepage loss. An additional seepage loss of $6.7 \mathrm{ft}^{3} / \mathrm{s}$ was calculated for the reach of the Virgin River between Bloomington, Utah, and the Utah/Arizona State line. This loss in flow is small compared to total flow in the river and is comparable to the rated error in streamflow measurements in this reach; consequently, it should be used with caution.

Littlefield Springs were studied to determine the fraction of its discharge that originates as upstream seepage from the Virgin River and residence time of this water in the subsurface. Geochemical and environmental tracer data from groundwater and surface-water sites in the Virgin River Gorge area suggest that discharge from Littlefield Springs is a mixture of modern (post-1950s) seepage from the Virgin River upstream of the springs and older groundwater from a regional carbonate aquifer. Concentrations of the chlorofluorocarbons (CFCs) CFC-12 and CFC-113, chloride/fluoride and chloride/bromide ratios, and the stable isotope deuterium indicate that water discharging from Littlefield Springs is about 60 percent seepage from the Virgin River and about 40 percent discharge from the regional carbonate aquifer. The river seepage component was determined to have an average subsurface traveltime of about $26 \pm 1.6$ years before discharging at Littlefield Springs. Radiocarbon data for Littlefield Springs suggest groundwater ages from 1,000 to 9,000 years. Because these are mixed waters, the component of discharge from the carbonate aquifer is likely much older than the groundwater ages suggested by the Littlefield Springs samples.

If the dissolved-solids load from Dixie Hot Springs to the Virgin River were reduced, the irrigation water subsequently applied to agricultural fields in the St. George and Washington areas, which originates as water from the Virgin River downstream of Dixie Hot Springs, would have a lower dissolvedsolids concentration. Dissolved-solids concentrations in excess irrigation water draining from the agricultural fields are about $1,700 \mathrm{mg} / \mathrm{L}$ higher than the concentrations in the Virgin River water that is currently (2014) used for irrigation that contains inflow from Dixie Hot Springs; this increase results from evaporative concentration and dissolution of mineral salts in the irrigated agricultural fields. The water samples collected from drains downgradient from the irrigated areas are assumed to include the dissolution of all available minerals precipitated in the soil during the previous irrigation season. Based on this assumption, a change to more dilute irrigation water will not dissolve additional minerals and increase the dissolvedsolids load in the drain discharge. Following the hypothetical 


\section{Hydrosalinity Studies of the Virgin River, Dixie Hot Springs, and Littlefield Springs, Utah, Arizona, and Nevada}

reduction of salts from Dixie Hot Springs, which would result in more dilute Virgin River irrigation water than is currently used, the dissolution of minerals left in the soil from the previous irrigation season would result in a net increase in dissolved-solids concentrations in the drain discharge, but this increase should only last one irrigation season. After one (or several) seasons of irrigating with more dilute irrigation water, mineral precipitation and subsequent re-dissolution beneath the agricultural fields should be greatly reduced, leading to a reduction in dissolved-solids load to the Virgin River below the agricultural drains.

A mass-balance model was used to predict changes in the dissolved-solids load in the Virgin River if the salt discharging from Dixie Hot Springs were reduced or removed. Assuming that 33.4 or $26.7 \mathrm{ft}^{3} / \mathrm{s}$ of water seeps from the Virgin River to the groundwater system upstream of the Virgin River
Gorge Narrows, the immediate hypothetical reduction in dissolved-solids load in the Virgin River at Littlefield, Arizona is estimated to be 67,700 or 71,500 ton/yr, respectively. The decrease in dissolved-solids load in seepage from the Virgin River to the groundwater system is expected to reduce the load discharging from Littlefield Springs in approximately 26 years, the estimated time lag between seepage from the river and discharge of the seepage water, after subsurface transport, from Littlefield Springs. At that time, the entire reduction in dissolved solids seeping from the Virgin River is expected to be realized as a reduction in dissolved solids discharging from Littlefield Springs, resulting in an additional reduction of $24,700 \mathrm{ton} / \mathrm{yr}$ (based on $33.4 \mathrm{ft}^{3} / \mathrm{s}$ of seepage loss) or $21,000 \mathrm{ton} / \mathrm{yr}$ (based on $26.7 \mathrm{ft}^{3} / \mathrm{s}$ of seepage loss) in the river's dissolved-solids load at Littlefield. 


\section{Chapter 1. Introduction}

\author{
By Steven J. Gerner
}

The Virgin River, which begins in southwestern Utah and flows through the northwest corner of Arizona, contributes a substantial amount of dissolved solids (salt) to the Colorado River at Lake Mead in southeastern Nevada. Degradation of Colorado River water, by the addition of dissolved solids from the Virgin River, affects the suitability of the water for municipal, industrial, and agricultural use within the lower Colorado River Basin.

Public laws enacted in 1974 and 1984 established the Colorado River Basin Salinity Control Program, which authorized the planning and construction of numerous salinity-control projects in the basin to improve or prevent further degradation in the quality of Colorado River water used by the United States and Mexico (Bureau of Reclamation, 2005). The overarching goal of the Colorado River Basin Salinity Control Program and its participating federal agencies - the Bureau of Reclamation (Reclamation) and Bureau of Land Management of the U.S. Department of the Interior, and the Natural Resources Conservation Service of the U.S. Department of Agriculture-is the cost-effective reduction of salinity in the Colorado River.

The Virgin River upstream of Dixie Hot Springs has lower concentrations and loads of dissolved solids than its downstream reaches. Dixie Hot Springs (also known as La Verkin Springs or Pah Tempe Springs; fig. 1) are a major point source of dissolved solids to the Virgin River. Tributary streams, return flow from irrigated agricultural fields, and a wastewater treatment facility contribute water and dissolved solids to the river downstream of the spring inflow. Seepage losses from the Virgin River upstream of and near the Utah/Arizona State line cause a decrease in streamflow and dissolved-solids load, but inflow from Littlefield Springs to the river causes both streamflow and load to increase.

During 1972-81 and 1983-84, Reclamation studied the discharge of dissolved solids from Dixie Hot Springs, the transport of these salts in the Virgin River, and the feasibility of reducing inflow of these salts to the river. The studies determined that Dixie Hot Springs add an average annual dissolved-solids load of about 106,000 tons to the Virgin River (Bureau of Reclamation, 1981) and removing most of this salt would result in an initial reduction in the average annual dissolved-solids load in the river at Littlefield, Arizona, of about 52,000 tons (Bureau of Reclamation, 1984a). An additional reduction of 34,000 tons per year (ton/yr) was anticipated to begin 22 years later, after the reduced load carried by water seeping out of the Virgin River travels through the groundwater flow system and starts discharging at Littlefield Springs.
A desalinization project on Dixie Hot Springs, although technically feasible, was found by Reclamation studies to be less economical than other salt-mitigation projects in the Colorado River Basin (Bureau of Reclamation, 1984b). Since that time, changes in water-treatment technology and in the management of water in the Virgin River have encouraged Colorado River Basin Salinity Control Program participants and other government entities to reassess the fate and transport of the dissolved-solids load discharging from Dixie Hot Springs and the feasibility of removing these salts from the Virgin River. The U.S. Geological Survey (USGS), in cooperation with Reclamation and the Colorado River Basin Salinity Control Forum (an organization of the seven Colorado River Basin states Arizona, California, Colorado, Nevada, New Mexico, Utah, and Wyoming), conducted the present study to address these information needs. The results of this study are intended to improve the understanding of the distribution of dissolved-solids loads in the Virgin River and the fate of water and salt lost from the river through seepage near the Utah/ Arizona State line and to provide information needed for the consideration and development of possible salinity remediation alternatives in the Virgin River.

\section{Overview of Dissolved-Solids Sources to the Virgin River}

All water naturally contains dissolved solids as a result of the weathering and dissolution of minerals in soils and geologic formations. Major ions, such as bicarbonate, calcium, chloride, magnesium, potassium, silica, sodium, and sulfate, constitute most of the dissolved solids in water and are an indicator of salinity. Most dissolved solids in the Virgin River Basin are derived from natural sources. Anning and others (2007) found that salt-yielding Mesozoic-age sedimentary rocks, such as those in the Chinle and Moenkopi Formations, and Paleozoic- and Precambrian-age sedimentary rocks, such as the Callville and Redwall Limestones, were the most significant sources of dissolved solids in the Lower ColoradoLake Mead hydrologic accounting unit, which includes the Virgin River Basin. Precipitation runoff on the more easily weathered rock types found in the basin can transport large amounts of sediment and dissolved solids to reservoirs and streams (Utah Department of Environmental Quality, 2004).

Dissolved-solids concentrations in the Virgin River generally increase from the river's headwaters to its terminus. Concentrations in the river generally are less than 570 milligrams per liter $(\mathrm{mg} / \mathrm{L}$ ) (the 90 th percentile of daily 


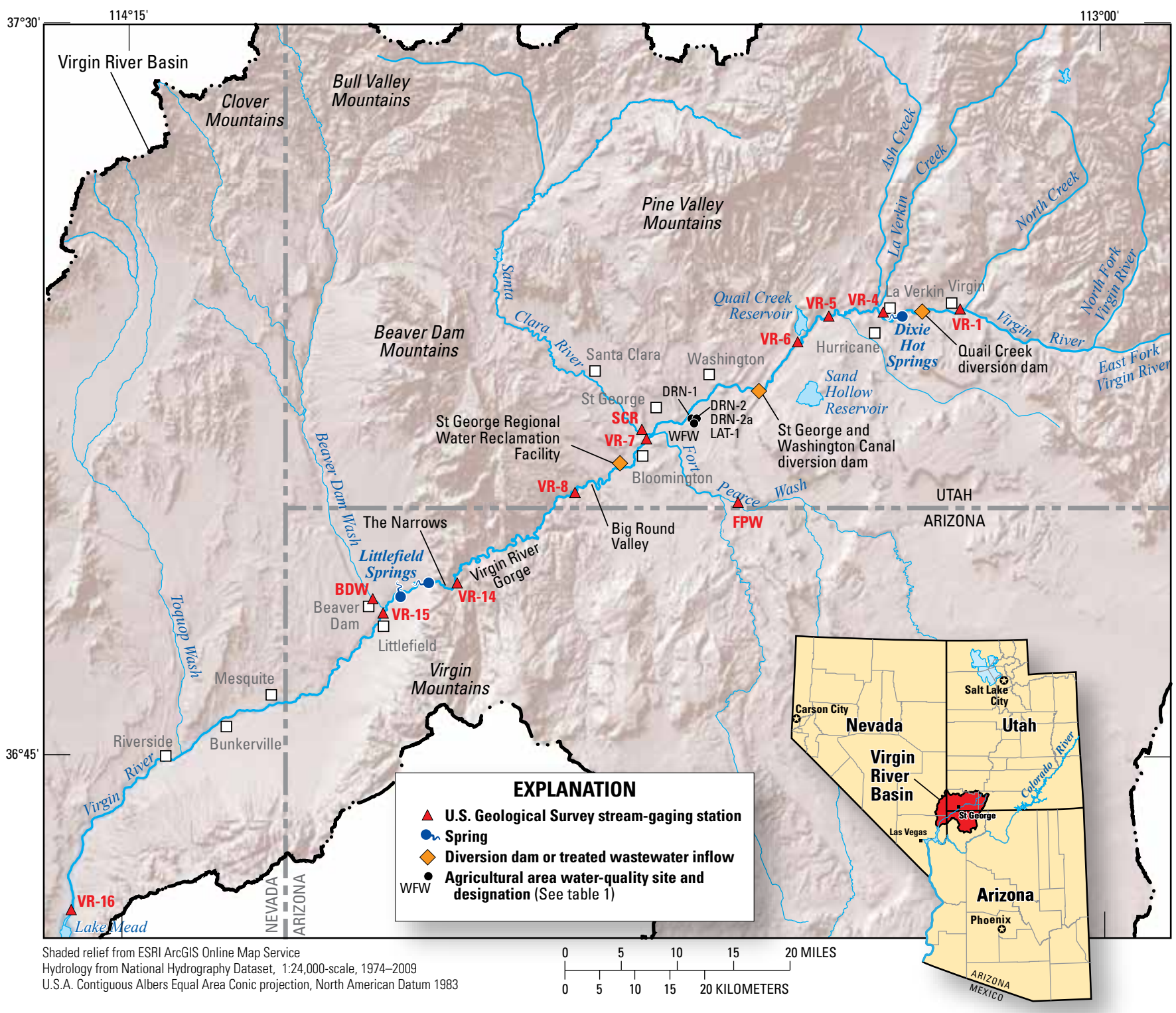

Figure 1. Geographic features and selected monitoring sites in the Virgin River Basin, Utah, Arizona, and Nevada.

mean dissolved-solids concentrations) at Virgin, Utah (site VR-1, fig. 1), but are about $1,800 \mathrm{mg} / \mathrm{L}$ at Littlefield, Arizona (site VR-15). Dissolved-solids concentrations in the Virgin River increase downstream because there is less inflow from tributary streams (which typically have lower concentrations than river water) and more inflow from groundwater discharge and surface-water runoff (which typically have higher concentrations than river water) than in the upstream reaches. Dissolved-solids concentrations are further increased through evaporation in streams and reservoirs and through transpiration by phreatophytes and riparian vegetation.

Groundwater discharging to the Virgin River and its tributaries is a substantial source of dissolved solids. For example, the Navajo Sandstone is a large water-bearing formation that is more than 2,000 feet (ft) thick in areas north and west of St. George, Utah (Cordova, 1978), which provides much of the base flow in the river (Herbert, 1995). Groundwater in the upper units of the sandstone has relatively low concentrations of dissolved solids (less than $500 \mathrm{mg} / \mathrm{L}$ ), whereas concentrations in the lower units range from 500 to $1,360 \mathrm{mg} / \mathrm{L}$ (Cordova, 1978). Dixie Hot Springs discharge to the Virgin River near the towns of Hurricane and La Verkin, Utah. Dissolvedsolids concentrations measured in this groundwater range from about 7,350 to $9,850 \mathrm{mg} / \mathrm{L}$. A portion of the groundwater discharging from Dixie Hot Springs is thought to come from deep aquifers through faults and fractures (Dutson, 2005; Nelson and others, 2009).

Like Dixie Hot Springs, Littlefield Springs are a large naturally occurring source of dissolved solids - average concentration of 2,780 $\mathrm{mg} / \mathrm{L}$ (table 1) - discharging to the Virgin River. The Virgin River loses flow through riverbed seepage in the reach between Bloomington, Utah (site VR-7) 
and the Narrows of the Virgin River Gorge, Arizona (site VR-14; fig. 1). A quantitative analysis of gains and losses in this and other reaches of the Virgin River has been presented in several studies, including those by Herbert (1995), Cole and Katzer (2000), Dixon and Katzer (2002), and Beck and Wilson (2006), and reported by the author to Reclamation and the Colorado River Basin Salinity Control Forum (Steven Gerner, U.S. Geological Survey, written commun., 2008). A previously proposed hypothesis is that seepage from the river between sites VR-7 and VR-14 (fig. 1) travels in the subsurface to an area near the downstream end of the Virgin River Gorge and just upstream of Littlefield, Arizona, where it discharges along a 6-mile (mi) reach of the river to several individual springs that make up Littlefield Springs. The hydrogeology of Littlefield Springs, including the quantity of water and source of dissolved solids in water discharged from the springs, was studied by Trudeau (1979), Trudeau and others (1983), and Metcalf (1995); sources of recharge and subsurface traveltimes to Littlefield Springs also were studied by Heilweil and others (2014) in an early phase of this study.

Basin-fill sediments consisting of the Tertiary-age Muddy Creek Formation and younger alluvial-fan and channel-fill deposits, discharge groundwater to the Virgin River downstream of the Virgin River Gorge and Littlefield, Arizona. West of Beaver Dam Wash, the concentration of dissolved solids in groundwater is generally less than $500 \mathrm{mg} / \mathrm{L}$; however the concentration in water from basin-fill sediments near the Virgin River east of Beaver Dam Wash is generally greater than $1,500 \mathrm{mg} / \mathrm{L}$ (Holmes and others, 1997). Additional water and dissolved solids are contributed to the Virgin River in ephemeral runoff from Beaver Dam Wash and runoff from the Beaver Dam and Virgin Mountains.

Human activities also affect dissolved-solids concentrations in the Virgin River. Water diverted from the Virgin River is used for irrigation, public supply, and generating hydropower. Not far downstream from the town of Virgin, almost twothirds of the flow in the Virgin River is diverted into the Quail Creek pipeline at the Quail Creek diversion dam; this water is conveyed to irrigated areas near La Verkin and Hurricane, Utah, and to the Sand Hollow and Quail Creek Reservoirs (fig. 1). Near Washington, Utah, a diversion dam diverts water from the river into the St. George and Washington Canal (SGWC) to irrigate crops in the area. Dissolved solids in irrigation water applied to agricultural fields become concentrated because of high evaporation rates in the area. Some of these dissolved minerals precipitate and accumulate in the upper layers of soil as an efflorescent salt crust during and after the irrigation season. Application of irrigation water during the following season flushes these salts into the underlying groundwater system and to agricultural drains that discharge to the Virgin River. Additionally, deep percolation of excess irrigation water results in the dissolution of salt from the soil profile and bedrock formations underlying agricultural areas that are served by the pipeline, reservoirs, and the SGWC.
Dissolved solids are added to, and concentrated in, water used for municipal supply in the St. George area. Treated wastewater discharges to the Virgin River from the St. George Regional Water Reclamation Facility (SGWRF). In the lower part of the Virgin River Basin, between the mouth of the Virgin River Gorge and Lake Mead, water and dissolved solids are diverted from the Virgin River for agricultural and municipal uses, primarily near the towns of Littlefield, Arizona; and Mesquite, Bunkerville, and Riverside, Nevada. Dixon and Katzer (2002) estimated that about 55,000 acre-feet per year (acre-ft/yr) of groundwater discharges downstream of Littlefield to Lake Mead in Nevada, a portion of which likely originates as excess irrigation water and contains greater concentrations of dissolved solids that returns to the river through the subsurface.

\section{Purpose and Scope}

Although additional data collection and analyses have been conducted since the Reclamation studies, some key questions about the hydrology of the Virgin River Basin, and sources and distribution of the dissolved-solids load have persisted. The overall objective of this study is to improve the understanding of the transport of dissolved solids in the Virgin River Basin, particularly those discharged from Dixie Hot Springs, using data collected through 2010. The report is organized into chapters that focus on these specific study objectives:

1. Determine the current (2014) discharge and dissolvedsolids concentrations in water from Dixie Hot Springs and identify seasonal variations in these values. Chapter 2 documents the quantity of water and dissolved solids discharged from Dixie Hot Springs during synoptic measurements made in 2009-10.

2. Acquire additional streamflow and water-quality data to improve the estimates of annual dissolved-solids load for selected sites on the Virgin River and its tributaries. Chapter 3 presents estimated annual dissolved-solids loads at several stream-gaging stations for periods during water years 1992-2010.

3. Determine the amount and fate of the dissolved-solids load lost from the Virgin River as seepage to groundwater in the reach between the gaging station near Bloomington, Utah, and the gaging station above the Narrows in the Virgin River Gorge, Arizona. Chapter 4 describes the average seepage losses of water and dissolved solids from the Virgin River in this reach.

4. Determine the sources of groundwater discharging at Littlefield Springs and the approximate age of this discharge. Chapter 5 presents findings on the fraction of groundwater discharging from Littlefield Springs that originates as upstream river seepage and the average subsurface traveltime of seepage water and of other potential sources of recharge to the springs. 
5. Determine if a reduction in the dissolved-solids load in the Virgin River associated with the hypothetical removal of dissolved solids from Dixie Hot Springs discharge will affect the dissolved-solids load in water discharging from downstream irrigated agricultural areas. Chapter 6 discusses findings on the potential for increased dissolvedsolids loading from agricultural fields irrigated with water from the Virgin River that would be more dilute than it is at present if the inflow of dissolved solids from Dixie Hot Springs were reduced.

6. Assess the effect of removing dissolved solids from Dixie Hot Springs discharge on the annual dissolved-solids load in the Virgin River. Chapter 7 presents calculations from a mass-balance model used to determine dissolved-solids loads in the Virgin River before and after the hypothetical reduction of salt from Dixie Hot Springs to the river.

\section{Water-Quality and Discharge Data Collected for this Study}

Monitoring sites where water-quality and discharge data were collected for this study are listed in table 1. Field waterquality parameters were measured and laboratory analyses of geochemical constituents were made on water samples collected from several sites in the Virgin River Basin during this study. Field parameters included specific conductance, $\mathrm{pH}$, temperature, dissolved oxygen, and barometric and total dissolved-gas pressure (at selected sites), and were measured according to USGS procedures (Wilde and Radtke, 1998).

Major and trace-ion chemical analyses made during this study included calcium, magnesium, sodium, potassium, chloride, sulfate, fluoride, silica, bicarbonate, manganese, bromide, and nutrients. These analyses were done by the USGS National Water-Quality Laboratory in Denver, Colorado.

Discharge at surface-water sampling sites was measured according to USGS procedures (Rantz and others, 1982). Measurements generally were made by wading using an acoustic Doppler velocimeter. Samples collected at stream-gaging stations may have an associated discharge determined from the stage-discharge rating rather than from a direct measurement. The discharge data can be accessed from the USGS National Water Information System (NWIS) database (U.S. Geological Survey, 2014).

In this report, "year" refers to "water year," - the 12-month period October 1 through September 30 that is designated by the calendar year in which it ends. Annual dissolved-solids loads and discharge values were computed for every water year (WY) for which data were available. For example, the annual dissolved-solids load for 1983 represents the computed load for the months October 1982 through September 1983. 
Table 1. Monitoring sites in the Virgin River Basin with water-quality or discharge data presented in this report.

[ROE, residue on evaporation at 180 degrees Celsius; $\mathrm{mg} / \mathrm{L}$, milligrams per liter; $\mu \mathrm{S} / \mathrm{cm}$ at $25^{\circ} \mathrm{C}$, microsiemens per centimeter at 25 degrees Celsius; UT, Utah; AZ, Arizona; NV, Nevada; - , no data]

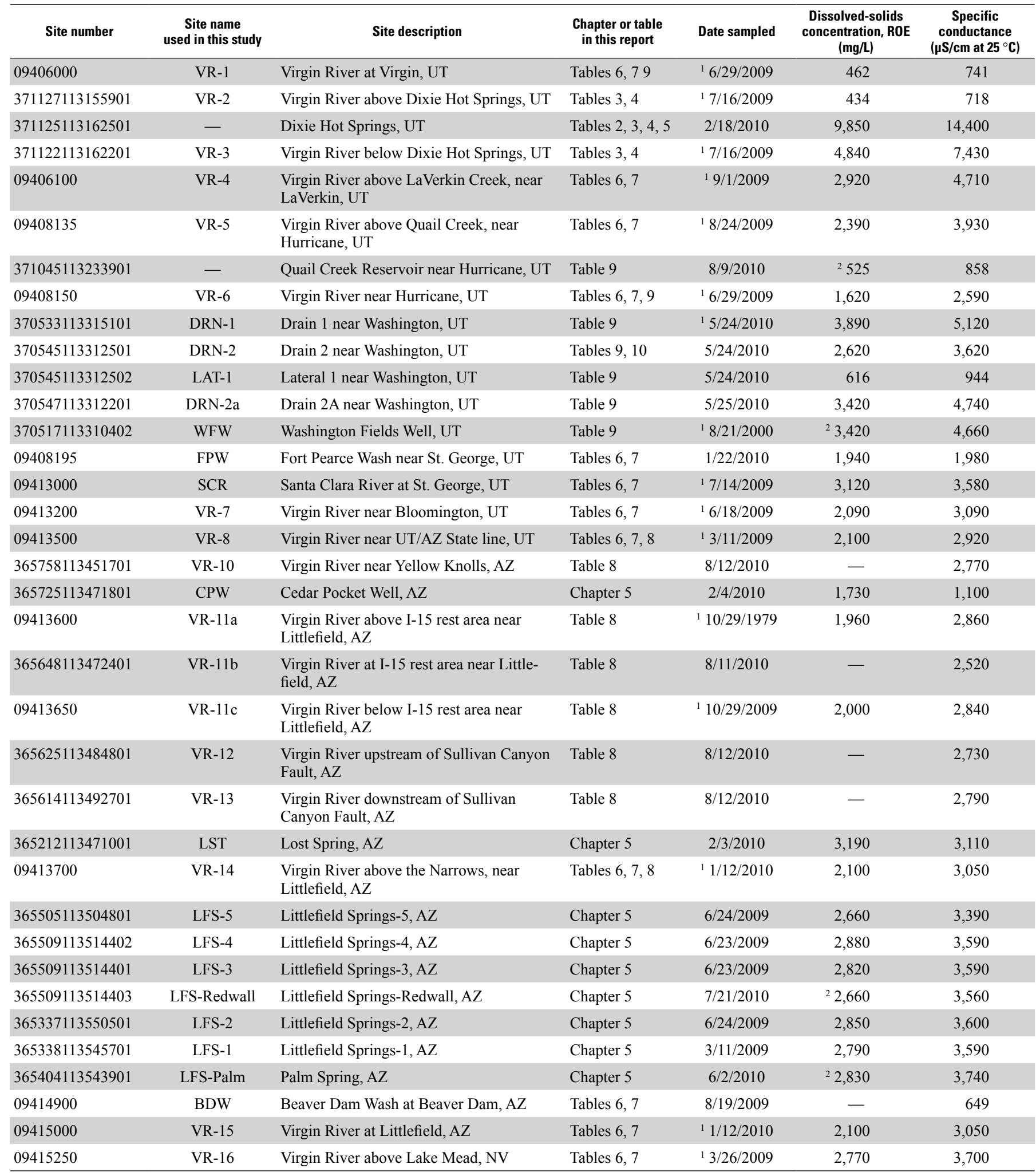

${ }^{1}$ More than one water-quality analysis with a dissolved-solids concentration available in U.S. Geological Survey National Water Information System database.

${ }^{2}$ Dissolved-solids concentration determined as the sum of constituents. 


\section{References Cited}

Anning, D.W., Bauch, N.J., Gerner, S.J., Flynn, M.E., Hamlin, S.N., Moore, S.J., Schaefer, D.H., Anderholm, S.K., and Spangler, L.E., 2007, Dissolved solids in basin-fill aquifers and streams in the Southwestern United States: U.S. Geological Survey Scientific Investigations Report 2006-5315, $336 \mathrm{p}$.

Beck, D.A., and Wilson, J.W., 2006, Discharge and physical-property measurements from Virgin River Narrows, Arizona, to Lake Mead, Nevada, February 12, 2003: U.S. Geological Survey Scientific Investigations Report 20055286, 10 p., accessed April 1, 2008, at http://pubs.water. usgs.gov/sir2005-5286.

Bureau of Reclamation, 1981, La Verkin Springs Unit, UtahConcluding report: Colorado River Water Quality Improvement Program, Point Source Division, 25 p.

Bureau of Reclamation, 1984a, La Verkin Springs Unit (Utah)-Composite of reports, 1983-84 La Verkin Springs study: Bureau of Reclamation, Lower Colorado Region, variously paginated.

Bureau of Reclamation, 1984b, La Verkin Springs Unit (Utah)_-Preliminary findings report: Bureau of Reclamation, Lower Colorado Region, 12 p.

Cole, Erin, and Katzer, Terry, 2000, Analysis of gains and losses in Virgin River flow between Bloomington, Utah and Littlefield, Arizona: Las Vegas, Nev., Southern Nevada Water Authority, variously paginated.

Cordova, R.M., 1978, Ground-water conditions in the Navajo Sandstone in the central Virgin River Basin, Utah: Utah Department of Natural Resources Technical Publication no. $61,66 \mathrm{p}$.

Dixon, G.L., and Katzer, Terry, 2002, Geology and hydrology of the lower Virgin River Valley in Nevada, Arizona, and Utah: Virgin Valley Water District Report VVWD-01, $126 \mathrm{p}$.

Dutson, S.J., 2005, Effects of Hurricane Fault architecture on groundwater flow in the Timpoweap Canyon of southwestern Utah: Provo, Utah, Brigham Young University, Master of Science Thesis, $57 \mathrm{p}$.

Heilweil, V.M., Sweetkind, D.S., and Gerner, S.J., 2014, Innovative environmental tracer techniques for evaluating sources of spring discharge from a carbonate aquifer bisected by a river: Ground Water, v. 52, p. 71-83. doi: $10.111 /$ gwat.12030.
Herbert, L.R., 1995, Seepage study of the Virgin River from Ash Creek to Harrisburg Dome, Washington County, Utah: Utah Department of Natural Resources Technical Publication no. 106,8 p.

Holmes, W.F., Pyper, G.E., Gates, J.S., Schaefer, D.H., and Waddell, K.M., 1997, Hydrology and water quality of the Beaver Dam Wash area, Washington County, Utah, Lincoln County, Nevada, and Mohave County, Arizona: U.S. Geological Survey Water-Resources Investigations Report 97-4193, $71 \mathrm{p}$.

Metcalf, L., 1995, Ground water-surface water interactions in the lower Virgin River area, Arizona and Nevada: Las Vegas, Nev., University of Nevada, Master of Science Thesis, $180 \mathrm{p}$.

Nelson, S.T., Mayo, A.L., Gilfillan, Stuart, Dutson, S.J., Harris, R.A., Shipton, Z.K., and Tingey, D.G., 2009, Enhanced fracture permeability and accompanying fluid flow in the footwall of a normal fault: the Hurricane fault at Pah Tempe hot springs, Washington County, Utah: Geological Society of America Bulletin, v. 121, no. 1-2, p. 236-246.

Rantz, S.E., and others, 1982, Measurement and computation of streamflow-Volume 1. Measurement of stage and discharge. Volume 2. Computation of discharge: U.S. Geological Survey Water-Supply Paper 2175, 631 p.

Trudeau, D.A., 1979, Hydrogeologic investigation of the Littlefield Springs: Reno, Nev., University of Nevada, Master of Science Thesis, 136 p., 3 pls.

Trudeau, D.A., Hess, J.W., and Jacobson, R.L., 1983, Hydrogeology of the Littlefield Springs, Arizona: Ground Water, v. 21 , no. 3 , p. $325-333$.

U.S. Geological Survey, 2014, National Water Information System (NWISWeb): U.S. Geological Survey database, accessed March 28, 2014, at http://waterdata.usgs.gov/nwis.

Utah Department of Environmental Quality, 2004, TMDL water quality study of the Virgin River watershed: Utah Department of Environmental Quality, Division of Water Quality, variously paginated, accessed October 2007, at http://www.waterquality.utah.gov/TMDL/Virgin_River Watershed_TMDL.pdf.

Wilde, F.D., and Radtke, D.B., 1998, National field manual for the collection of water-quality data, Chapter A6: Field Measurements: U.S. Geological Survey Techniques of WaterResources Investigations, book 9, chap. A6, 233 p. 


\title{
Chapter 2. Discharge and Dissolved-Solids Load Contributed by Dixie Hot Springs to the Virgin River
}

\author{
By Briant A. Kimball and Steven J. Gerner
}

Dixie Hot Springs are located along approximately 2,000 ft of the bed and banks of the Virgin River near the mouth of Timpoweap Canyon, near La Verkin, Utah (fig. 2). The springs issue from highly fractured rocks upstream of where the Hurricane Fault crosses the river. The Hurricane Fault is a normal fault that marks the transition from the Colorado Plateau physiographic province on the east to the Basin and Range on the west (Dutson, 2005). The Permian-age Toroweap Formation, which includes carbonate rocks, is exposed at the hot springs and along the river in Timpoweap Canyon.

Measurements made periodically from 1960 to 1982 at Dixie Hot Springs indicate an average discharge of 11 cubic feet per second $\left(\mathrm{ft}^{3} / \mathrm{s}\right)$ and an average dissolved-solids concentration of about 9,440 mg/L. Table 2 lists selected historical measurements made at Dixie Hot Springs and those made by this study. The average water temperature of spring discharge

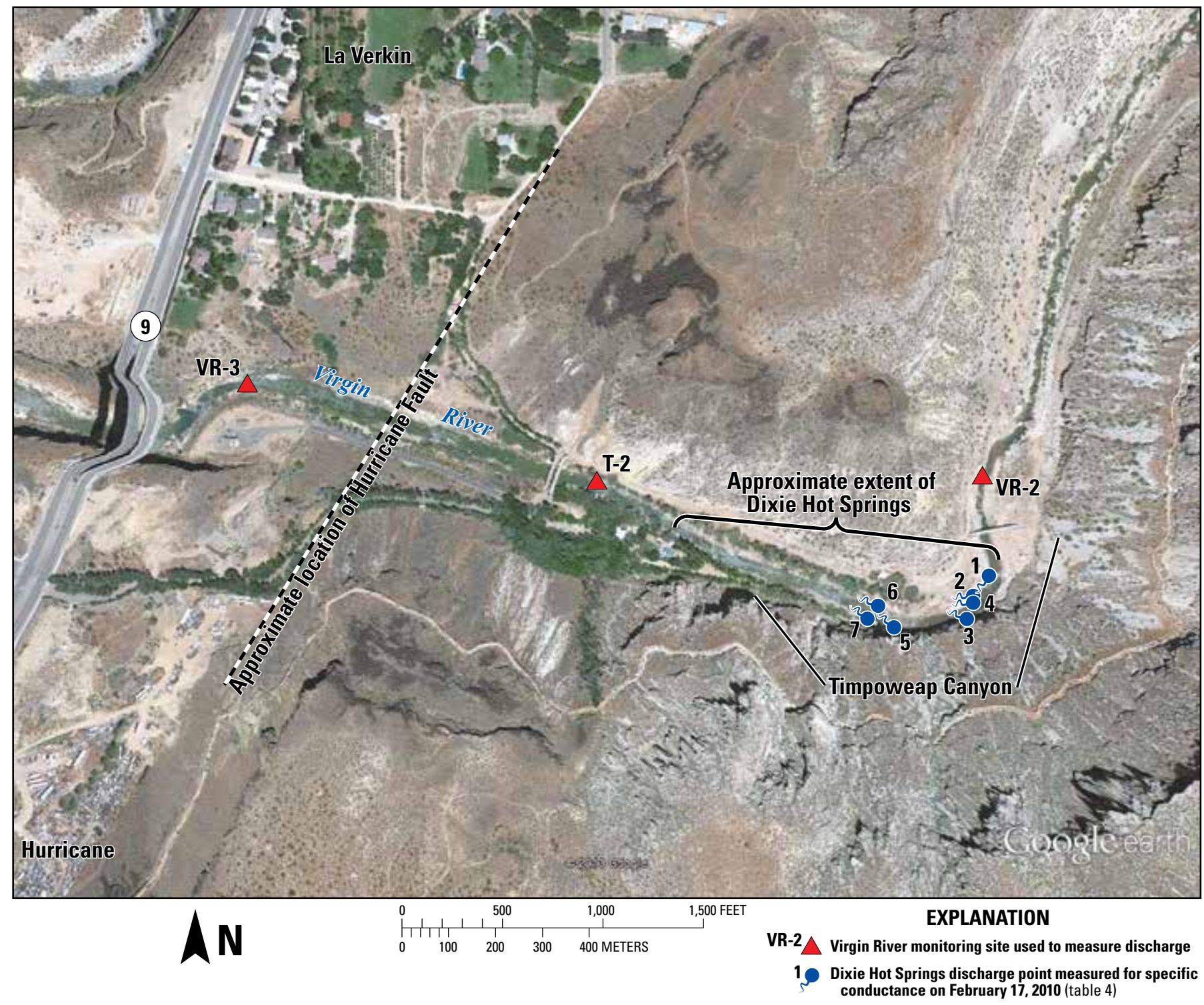

Figure 2. Geographic features, selected discharge points from Dixie Hot Springs, and monitoring sites on the Virgin River near Dixie Hot Springs, Utah. 
is 40.5 degrees Celsius $\left({ }^{\circ} \mathrm{C}\right)$ (Everitt and Einert, 1994). Estimates of dissolved-solids load from Dixie Hot Springs associated with measurements or estimates of discharge and dissolved-solids concentrations during 1960-82 and 1995-2010 ranged from 87,400 to 113,500 ton/yr and averaged 98,900 ton/yr (table 2).

Discharge from Dixie Hot Springs is likely a mixture of shallow groundwater recharged from the Virgin River and groundwater that has circulated deeply along the Hurricane Fault; the deep groundwater has a much higher dissolvedsolids concentration than the shallow groundwater. On the basis of geothermometer aquifer temperatures, Dutson (2005) estimated a circulation depth of about 1-2 mi for a component of the water discharging from the springs.

In the spring of 1985, several sinkholes formed along the Virgin River about 2 mi upstream of Dixie Hot Springs (Everitt and Einert, 1994). The largest sinkhole intercepted a reported 30-40 $\mathrm{ft}^{3} / \mathrm{s}$ of flow from the river during parts of that summer. In July 1985, flow in the river was diverted at the Quail Creek diversion dam, upstream of the sinkhole. In September 1985, a levee was built to separate the river from the sinkholes and flow was returned to the river. Discharge from the hot springs in October 1985 increased to an estimated $20 \mathrm{ft}^{3} / \mathrm{s}$ (Everitt and Einert, 1994), water temperature decreased to $36.0^{\circ} \mathrm{C}$, dissolved-solids concentration decreased to an estimated $7,070 \mathrm{mg} / \mathrm{L}$, and dissolved-solids load increased to 139,300 ton/yr. By 1989, discharge from Dixie Hot Springs, as measured periodically by the Utah Department of Natural Resources, had decreased to near the historical average.

To estimate the annual discharge of dissolved solids (dissolved-solids load) from Dixie Hot Springs to the Virgin River, discharge, specific conductance, and concentrations of major ions and dissolved solids were measured several times during 2009-10 (table 3). Because groundwater from Dixie Hot Springs discharges from several areas along a reach of the river, multiple methods were used to determine flow and loads from the springs. The following sections describe the methods used to determine discharge in the Virgin River at sites upstream and downstream from Dixie Hot Springs. Discharge was then used with dissolved-solids concentration to estimate the dissolved-solids load to the Virgin River from Dixie Hot Springs.

\section{Discharge Determined from Area-Velocity Measurements}

To determine discharge from Dixie Hot Springs, paired area-velocity discharge measurements were made on the Virgin River at sites just upstream of Dixie Hot Springs (site VR-2) and just downstream of the springs (site VR-3; fig. 2). Stream velocity was measured with an acoustic Doppler velocimeter and stream discharge was computed using the midsection method described by Rantz and others (1982). This method consists of measuring the area and average velocity in a number of subsections (usually more than 20) along a cross section of the stream. Total discharge in the stream cross section is the sum of the discharges for all of the subsections. Net gains in discharge of 8.8 and $13.9 \mathrm{ft}^{3} / \mathrm{s}$ at different times on February 5, 2010 (table 4) are attributed to discharge from Dixie Hot Springs by subtracting the discharge measured at the upstream site VR-2 from the discharge measured at the downstream site VR-3.

\section{Discharge Determined from Stage-Discharge Relation}

Traditionally, the USGS has used the relation between areavelocity discharge measurements and associated stream stage (height of stream surface above a reference point) to calculate a time series of stream discharge based on a time series of stream-stage measurements. This stage-discharge relation method (Rantz and others, 1982) was used to determine the discharge of Dixie Hot Springs to the Virgin River during February 16-18, 2010. Pressure transducers were installed in the river at sites VR-2 and VR-3, which bound the reach known to contain discharge points for Dixie Hot Springs. The pressure transducers contained internal programming to convert water pressure, associated with depth of water over the transducer, to feet of stage in the river relative to a reference datum established for the measurement period. Discharge measurements were made at various stream stages throughout the measurement period to define a stage-discharge relation (equation shown on fig. 3). The mathematical expression of this relation was then applied to the collected time-series of stage data (stage was recorded every 15 minutes) resulting in a time series of discharge in the Virgin River at sites upstream and downstream of Dixie Hot Springs for this period (fig. 4).

The time for water to travel between sites VR-2 and VR-3 was determined by visually comparing changes in stage values at the sites with time. A time adjustment of about 40 minutes was applied to the downstream discharge values so they could be associated with upstream values. Stage (and discharge) generally decreased during the monitoring period, but the decline in stage became more rapid at about 11:30 PM on February 16,2010 , before starting to level out at about 2:30 AM on February 17, 2010 (fig. 4). Around 6:30 AM that morning, stage rapidly increased to the levels recorded prior to the start of the more rapid decrease. None of the stage values recorded 
Table 2. Selected measurements of discharge, specific conductance, and dissolved-solids concentrations and loads, Dixie Hot Springs, Utah, 1960-2010.

$\left[\mathrm{ft} / \mathrm{s}\right.$, cubic feet per second; $\mu \mathrm{S} / \mathrm{cm}$ at $25^{\circ} \mathrm{C}$, microsiemens per centimeter at 25 degrees Celsius; $\mathrm{mg} / \mathrm{L}$, milligrams per liter; ton/yr, tons per year; -, not measured or calculated; E, estimated; values in italics are calculated using these equations: Dissolved-solids concentration = (specific conductance) $(0.6827)-93.748$, relation shown on fig. 8; Dissolved-solids load $=($ discharge $)($ dissolved-solids concentration $)(0.985)]$

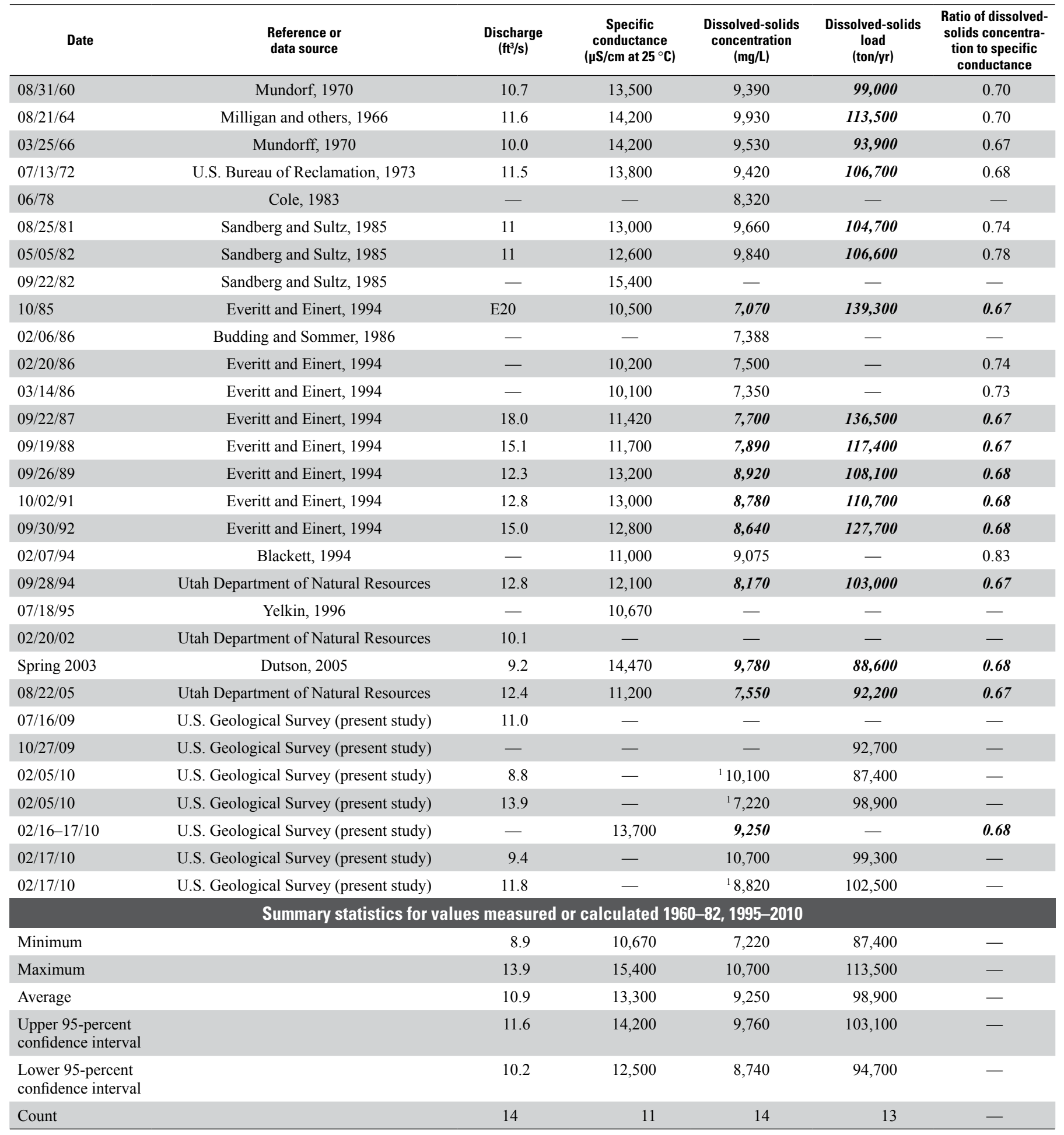

${ }^{1}$ Dissolved-solids concentration calculated from discharge and dissolved-solids load (see table 4). 


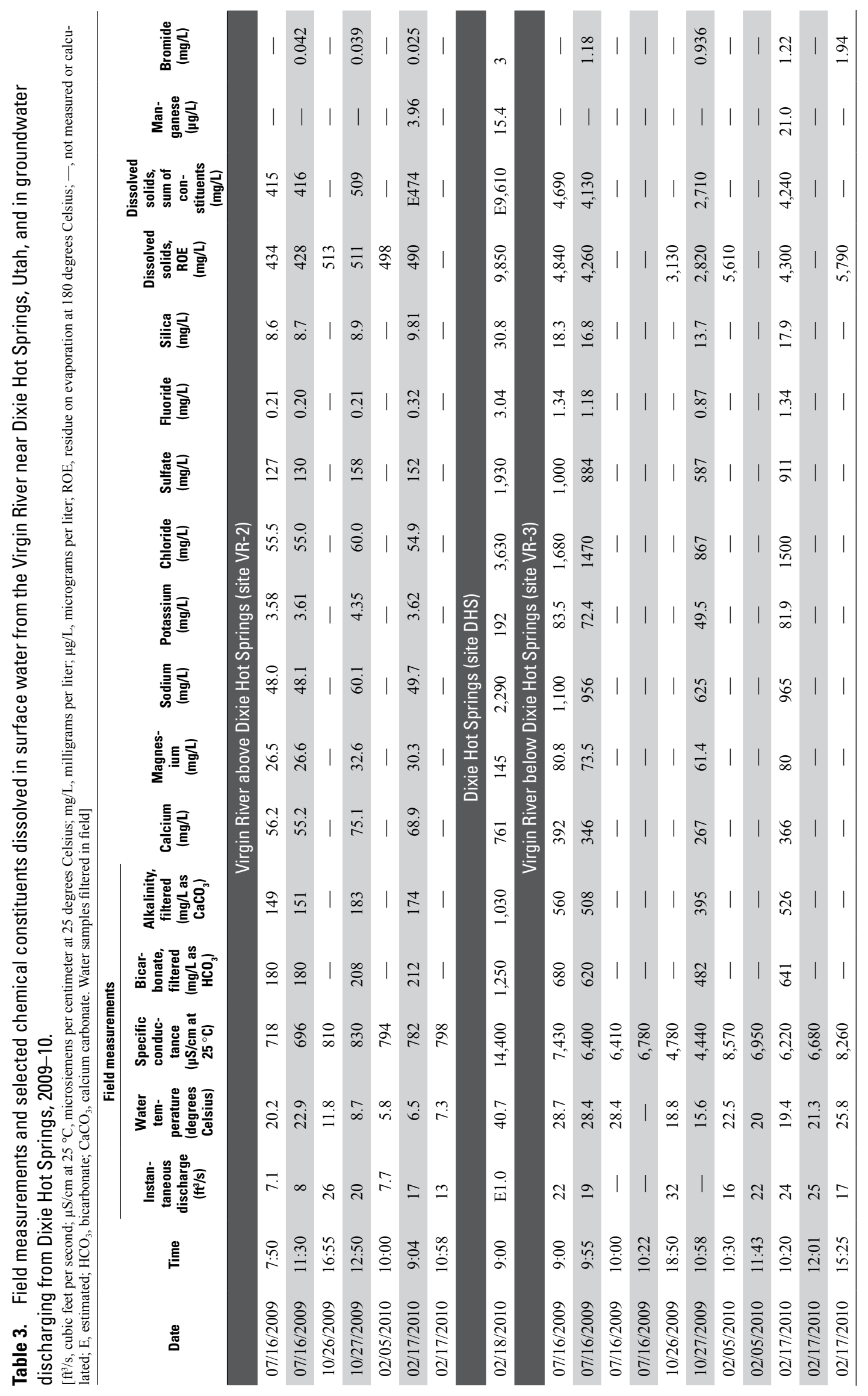


Table 4. Discharge and dissolved-solids concentration and load in the Virgin River above and below Dixie Hot Springs, Utah, and calculated discharge and dissolved-solids concentration and load from Dixie Hot Springs, 2009-10.

[ $\mathrm{ft}^{3} / \mathrm{s}$, cubic feet per second; mg/L, milligrams per liter; ton/yr, tons per year; —, not calculated; ROE, residue on evaporation at 180 degrees Celsius]

\begin{tabular}{|c|c|c|c|c|c|c|c|c|c|c|c|}
\hline \multirow[b]{2}{*}{ Date } & \multirow[b]{2}{*}{$\begin{array}{c}\text { Discharge } \\
\text { measurement } \\
\text { method }\end{array}$} & \multicolumn{3}{|c|}{$\begin{array}{c}\text { Virgin River above Dixie Hot Springs } \\
\text { (site VR-2) }\end{array}$} & \multicolumn{3}{|c|}{$\begin{array}{l}\text { Virgin River below Dixie Hot Springs } \\
\text { (site VR-3) }\end{array}$} & \multicolumn{4}{|c|}{ Dixie Hot Springs } \\
\hline & & $\begin{array}{l}\text { Discharge } \\
\left(\mathbf{f t}^{3} / \mathbf{s}\right)\end{array}$ & $\begin{array}{l}\text { Dissolved- } \\
\text { solids } \\
\text { concentra- } \\
\text { tion (mg/L) }\end{array}$ & $\begin{array}{l}\text { Dissolved- } \\
\text { solids load } \\
\text { (ton/yr) }\end{array}$ & $\begin{array}{l}\text { Discharge } \\
\left(\mathrm{ft}^{3} / \mathbf{s}\right)\end{array}$ & $\begin{array}{l}\text { Dissolved- } \\
\text { solids } \\
\text { concentra- } \\
\text { tion (mg/L) }\end{array}$ & $\begin{array}{l}\text { Dissolved- } \\
\text { solids load } \\
\text { (ton/yr) }\end{array}$ & $\begin{array}{c}\text { Calculated } \\
\text { discharge } \\
\left(\mathrm{ft}^{3} / \mathbf{s}\right)\end{array}$ & $\begin{array}{l}\text { Discharge } \\
\text { rated }\end{array}$ & $\begin{array}{l}\text { Calculated } \\
\text { dissolved- } \\
\text { solids load } \\
\text { (ton/yr) }\end{array}$ & $\begin{array}{l}\text { Calculated } \\
\text { dissolved- } \\
\text { solids } \\
\text { concentration } \\
\text { (mg/L) }\end{array}$ \\
\hline $7 / 16 / 2009$ & $\begin{array}{l}\text { Slug tracer } \\
\text { injection }\end{array}$ & 8.0 & ${ }^{1} 381$ & 3,010 & 19.0 & ${ }^{5} 4,410$ & 82,600 & 11.0 & Fair & ${ }^{6}-$ & ${ }^{6}-$ \\
\hline $10 / 27 / 2009$ & $\begin{array}{l}\text { Slug tracer } \\
\text { injection }\end{array}$ & 19.6 & ${ }^{1} 473$ & 9,130 & 34.8 & ${ }^{1} 2,970$ & 101,900 & ${ }^{7}-$ & Poor & 92,700 & ${ }^{7}-$ \\
\hline $2 / 5 / 2010$ & Area-velocity & 7.7 & ${ }^{2} 498$ & 3,780 & 16.5 & ${ }^{2} 5,610$ & 91,200 & 8.8 & Fair & 87,400 & 10,100 \\
\hline $2 / 5 / 2010$ & Area-velocity & 8.6 & ${ }^{2} 498$ & 4,220 & 22.5 & ${ }^{1} 4,650$ & 103,100 & 13.9 & Fair & 98,900 & 7,220 \\
\hline $2 / 16-17 / 2010$ & Stage-discharge & 15.5 & ${ }^{3} 433$ & 6,610 & 24.9 & ${ }^{3} 4,320$ & 105,900 & 9.4 & Good & 99,300 & 10,700 \\
\hline $2 / 17 / 2010$ & $\begin{array}{l}\text { Slug tracer } \\
\text { injection }\end{array}$ & 12.8 & ${ }^{4} 451$ & 5,690 & 24.6 & ${ }^{4} 4,470$ & 108,200 & 11.8 & Fair & 102,500 & 8,820 \\
\hline \multicolumn{12}{|c|}{ Summary statistics } \\
\hline \multicolumn{8}{|l|}{ Average } & 11.0 & & 96,200 & 9,210 \\
\hline \multicolumn{8}{|c|}{ Standard deviation } & 2.0 & & 6,050 & 1,540 \\
\hline \multicolumn{8}{|c|}{ Upper 95-percent confidence interval } & 12.8 & & 101,500 & 10,700 \\
\hline \multicolumn{8}{|c|}{ Lower 95-percent confidence interval } & 9.2 & & 90,900 & 7,700 \\
\hline \multicolumn{12}{|c|}{${ }^{1}$ Dissolved-solids concentration calculated from ROE/specific conductance relation. Specific conductance was measured at the time of discharge measurement. } \\
\hline \multicolumn{12}{|c|}{$\begin{array}{l}{ }^{3} \text { Dissolved-solids concentration calculated from ROE/specific conductance relation. Average of values that met the criteria for stage-discharge calculations during the monitoring period. } \\
{ }^{4} \text { Dissolved-solids concentration calculated from ROE/specific conductance relation. The specific conductance used is the average value measured during the test. }\end{array}$} \\
\hline \multicolumn{12}{|c|}{${ }^{5}$ Dissolved-solids concentration calculated from ROE/specific conductance relation. The specific conductance used is the average of values measured at the beginning and end of the test. } \\
\hline \multicolumn{12}{|c|}{$\begin{array}{l}{ }^{7} \text { The discharge measurement at site VR-2 is considered 'poor' because of a poor relation between millivolt readings and bromide concentrations. As a result, discharge and dissolved- } \\
\text { solids concentrations from Dixie Hot Springs are not calculated. However, the dissolved-solids load at site VR-2 was used to compute a dissolved-solids load from Dixie Hot Springs because } \\
\text { the error in the load at site VR-2 is probably less than } 5 \text { percent of the load from the hot springs. }\end{array}$} \\
\hline
\end{tabular}

during the periods of rapidly changing stage were used in the calculation of average discharge. In addition, discharge calculations from stage data were limited to the range of stage and discharge associated with discharge measurements (fig. 3). Consequently, because of rapid stage changes and the limited range of measured discharge, only 900 of the nearly 2,400 stage values recorded were used in discharge computations for each site. The average of the discharge values during the measurement periods on February 16 and 17 (February 16, about 7:00 PM to 11:30 PM, and February 17, about 7:00 AM to 5:00 PM) was $15.5 \mathrm{ft}^{3} / \mathrm{s}$ at VR-2 and $24.9 \mathrm{ft}^{3} / \mathrm{s}$ at VR-3 (table 4). Average discharge from Dixie Hot Springs $\left(9.4 \mathrm{ft}^{3} / \mathrm{s}\right)$ is the difference between these values.

\section{Discharge Determined from Tracer-Injection Methods}

Seepage studies provide the means to measure the gain or loss of streamflow that results from fluxes between groundwater and surface water (Winter and others, 1998). However, quantifying discharge in complex settings of inflow, such as the reach of the Virgin River that receives inflow from Dixie Hot Springs, presents challenges to traditional area-velocity measurement approaches because of possible flow in and out of short segments of the streambed and banks (hyporheic flow).

Instantaneous (slug) and continuous tracer-injection methods were used to measure discharge at selected sites on the Virgin River and to calculate inflow from Dixie Hot Springs. Salts, like the sodium bromide used in tracer injections done during this study, are conservative in that the bromide is not lost from the stream water through biological or chemical reactions. Several water samples were collected from the river and analyzed for major dissolved constituents during the tracer-injection tests; water temperature, specific conductance, and alkalinity were measured in the field during the tests (table 3).

\section{Slug Tracer-Injection Method}

An instantaneous injection (slug) of a known mass of tracer salt can be used to determine discharge (Kilpatrick and Cobb, 1985). Once the slug of tracer salt is well mixed with 


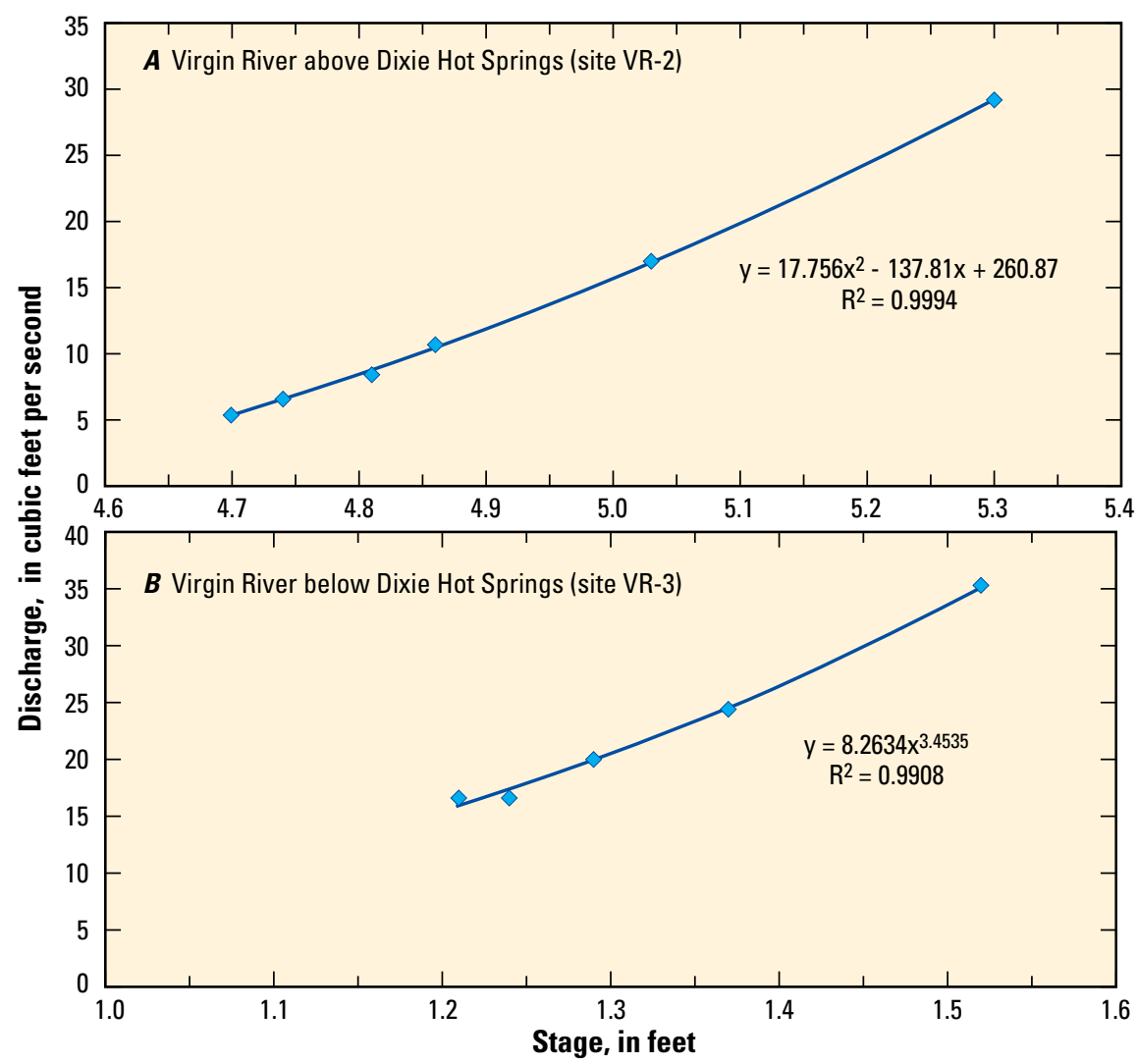

Figure 3. Relation of stage to discharge in the Virgin River at $A$, above Dixie Hot Springs (site VR-2) and $B$, below Dixie Hot Springs, Utah (site VR-3).

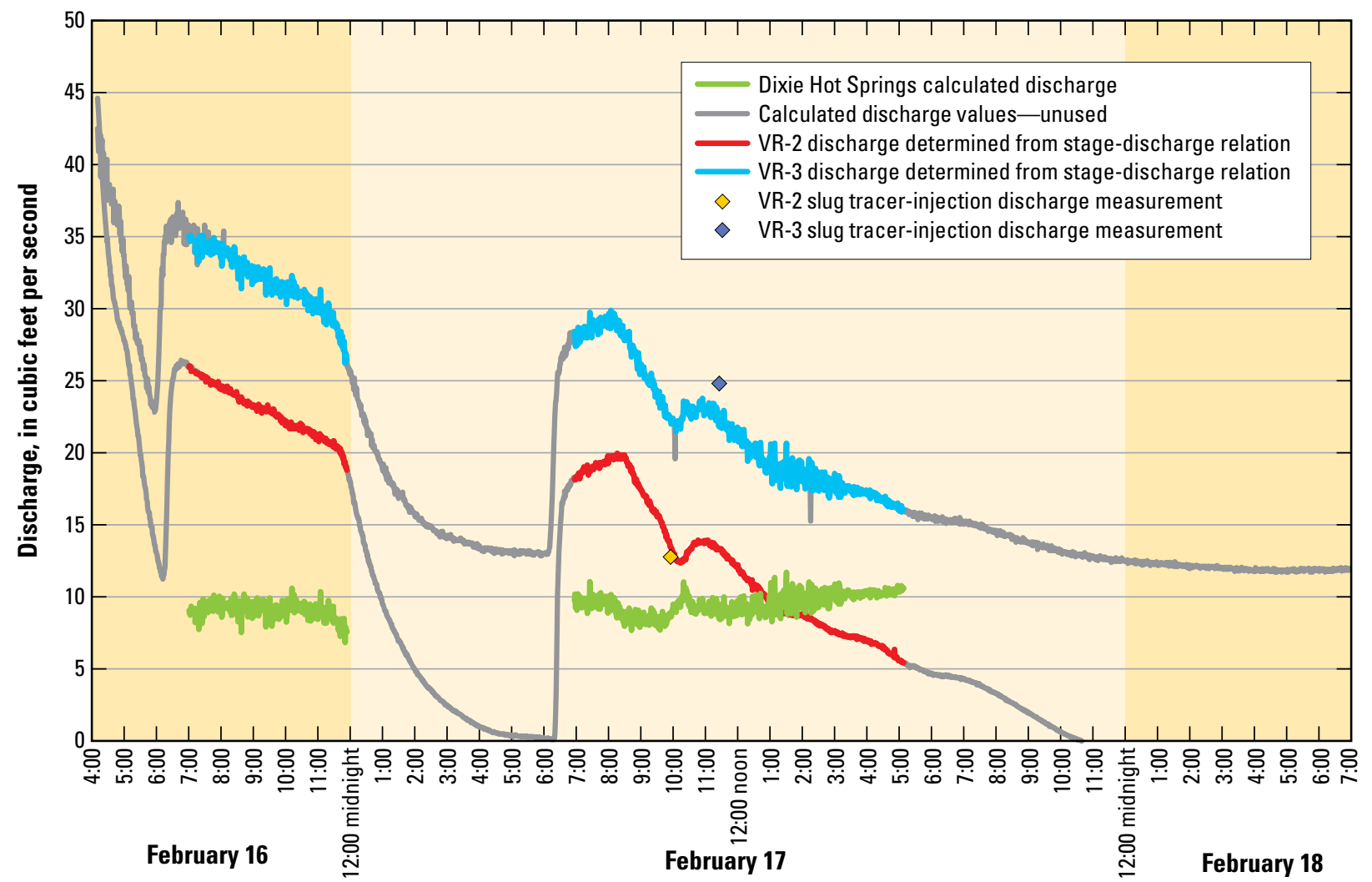

Figure 4. Discharge determined from the stage-discharge relation in the Virgin River upstream (VR-2) and downstream (VR-3) of Dixie Hot Springs, Utah, and from Dixie Hot Springs on February 16-18, 2010. 
the stream water, the method relies on the measurement of the tracer concentration as the tracer passes a point downstream (fig. 5). Inflow over a given stream reach is determined by using slug tracer injections upstream and downstream of the study reach, calculating a discharge at each site, and then calculating the difference in discharge. The difference is an estimate of net gain or loss of water in the selected reach. Both streamflow gains and losses may be occurring within the selected reach, but only net gain or loss can be defined from the slug tracer-injection method.

Instantaneous injections of a sodium bromide tracer were used to measure streamflow at the downstream and upstream ends of the reach on the Virgin River that includes Dixie Hot Springs three times during this study under various flow regimes. Sodium bromide was used because the bromide concentration can be measured with an ion-sensitive electrode positioned in the stream. Readings of millivolts were stored every 5 seconds in a data logger. These readings were related and converted to bromide concentration, providing a detailed profile of concentration as a function of time at the measurement point (fig. 6 shows results of the slug injections done on February 17, 2010). The area under the curve (in milligramseconds per liter, $\mathrm{mg}-\mathrm{s} / \mathrm{L}$, shown on fig. 6 ) is determined by integrating the concentration profile as a function of time. The mass of injected bromide (in milligrams) is divided by this area to obtain a value of discharge:

$$
Q_{2}=\left(M_{i n j} / A_{i n j}\right) * 0.0353
$$

where

$Q_{2} \quad$ is the downstream discharge from slug injection, in cubic feet per second;

$M_{i n j} \quad$ is the mass of the bromide tracer injected, in milligrams;

$A_{i n j} \quad$ is the area under the concentration-time profile, in milligram-seconds per liter; and

0.0353 is the conversion factor from liters per second to cubic feet per second.

Although the same mass of bromide was used for each slug injection, the concentrations measured at sites VR-2 and VR-3 were different, resulting in different calculated discharges (table 4). The total discharge from Dixie Hot Springs is assumed to be the net change in discharge between these sites and was calculated to be $11.0 \mathrm{ft}^{3} / \mathrm{s}$ on July 16,2009 , and $11.8 \mathrm{ft}^{3} / \mathrm{s}$ on February 17, 2010. A discharge from the springs is not reported for the slug tracer-injection test done on October 27, 2009, because of a poor relation between millivolt readings and bromide concentrations, and, therefore, a poor discharge measurement at site VR-2.

\section{Continuous Tracer-Injection Method}

A continuous tracer-injection test (Kilpatrick and Cobb, 1985) also was done on the reach of the Virgin River that contains Dixie Hot Springs on February 17, 2010. This method assumes that stream water, both in the channel and in the hyporheic zone, is well mixed with the tracer after an appropriate length of time. Once water in the stream and in the hyporheic zones is well mixed with the tracer, dilution of the tracer at any downstream location will indicate an increase in discharge caused by inflow from other sources. Although the continuous-injection method can indicate streamflow gain, the method cannot be used independently to quantify loss. As water is lost from the stream, no change in tracer concentration occurs in the water that remains in the stream.

The sodium bromide tracer was continuously injected into the Virgin River upstream of site VR-2. Natural background concentrations of bromide in the Virgin River at site VR-2 are low $(0.04 \mathrm{mg} / \mathrm{L})$, indicating that sources of water upstream from Dixie Hot Springs have low bromide concentrations. Dixie Hot Springs, with its unique chemical character, does contribute bromide to the Virgin River. A background bromide concentration of $1.9 \mathrm{mg} / \mathrm{L}$ was subtracted from concentrations determined at river sites located downstream from the springs during the test.

Tracer-concentration profiles resulting from the continuous tracer injection are illustrated in figure 7 . The temporal profiles for bromide from the Virgin River just upstream from where the tracer was added and at site VR-2 are unadjusted because of the low bromide concentration at the site upstream from the injection. An unplanned decrease in the discharge of the river at site VR-2 occurred during the injection period. The decrease in streamflow likely was a result of water withdrawn for

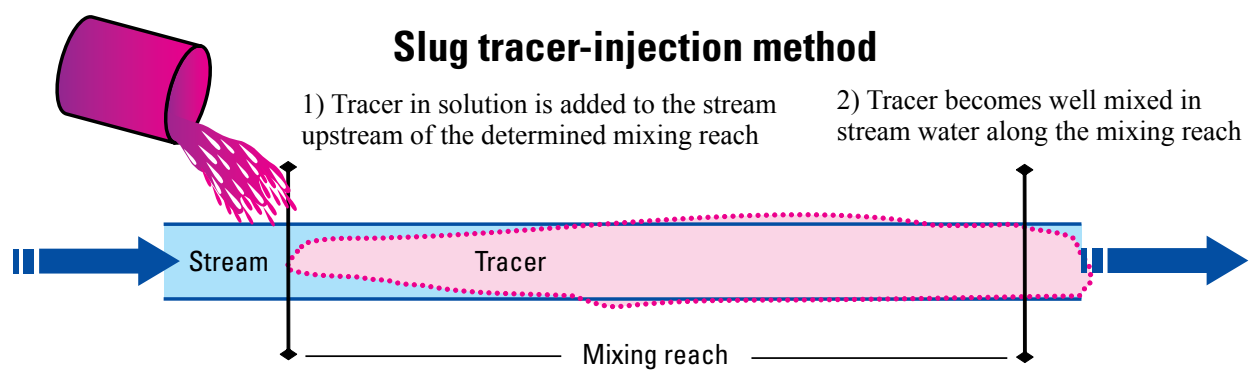

3) A time-series of tracer concentrations is measured downstream of the mixing reach allowing for the determination of the area under the concentration-time profile and the calculation of instantaneous discharge

Figure 5. Schematic diagram showing the slug tracer-injection method of measuring discharge. 


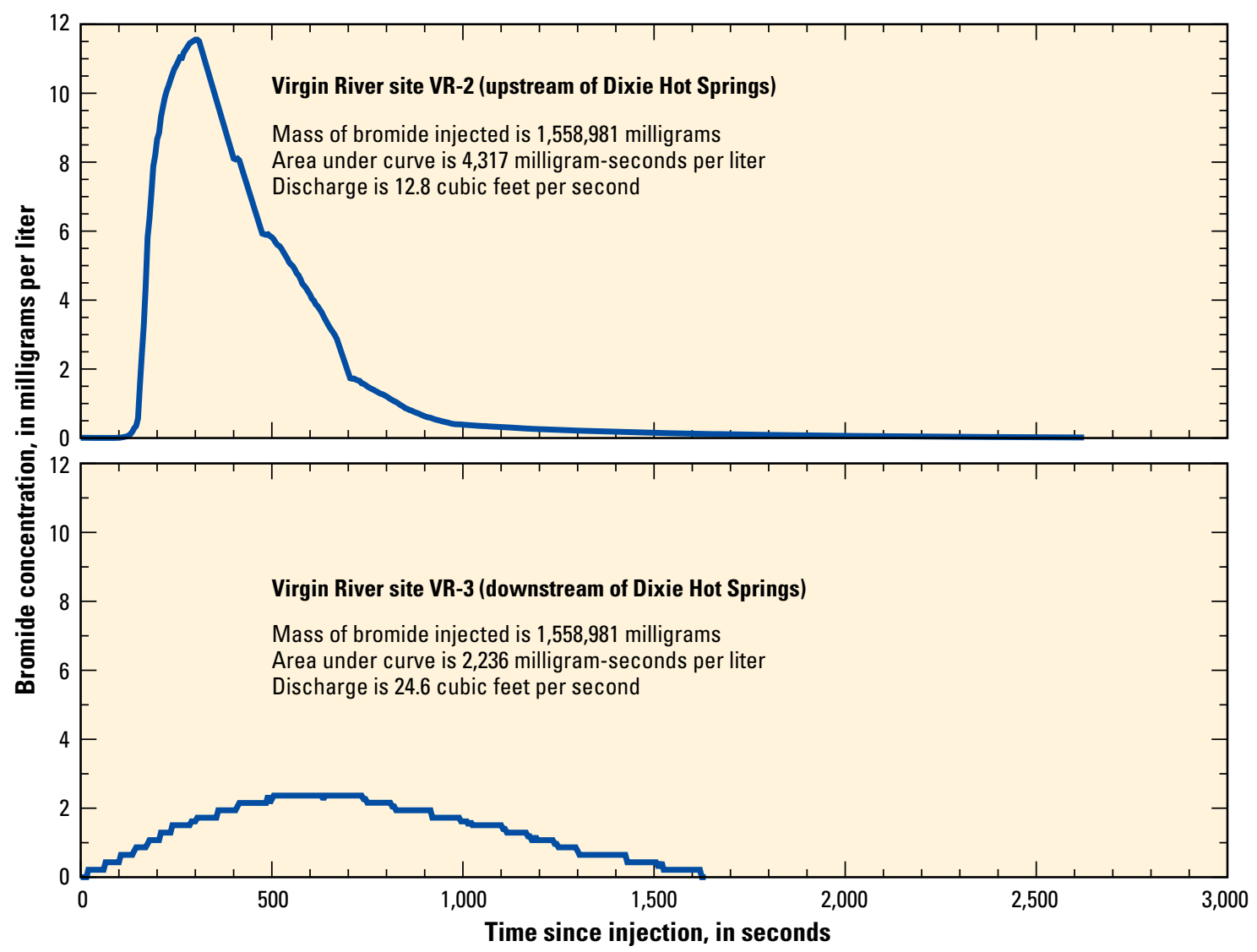

Figure 6. Variation in bromide concentration over time at sites VR-2 and VR-3 on the Virgin River, Utah, during slug tracer-injection tests on February 17, 2010.

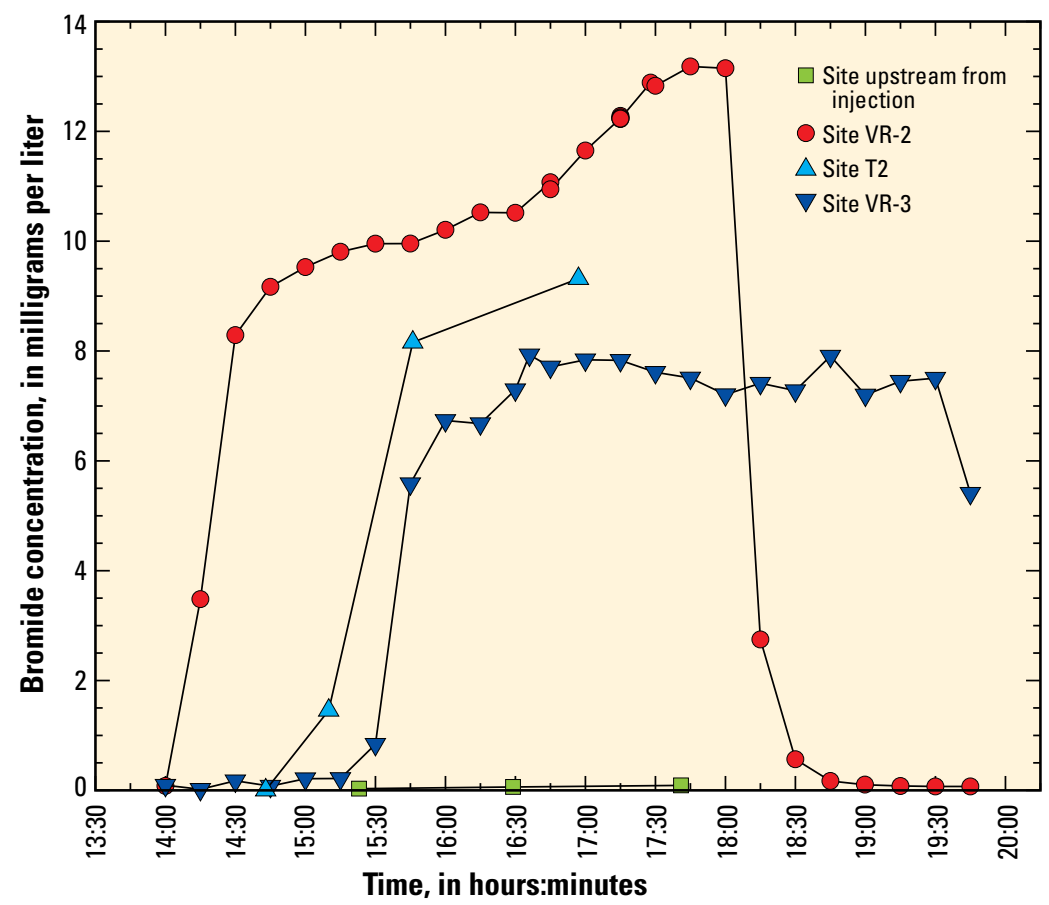

Figure 7. Variation in bromide concentration over time at selected sites on the Virgin River, Utah, during a continuous tracer-injection test on February 17, 2010. 
power generation and is indicated by the continued increasing concentration of bromide at site VR-2 during the test. Because the bromide concentrations did not stabilize at site VR-2 while the tracer was injected upstream, discharge at this site can not be calculated for this test.

Although the continuous injection was complicated by the variable flow entering the study reach, the concentration profiles do provide valuable information. The last two samples collected at site T2 (fig. 7) suggest that some dilution occurred between sites T2 and VR-3. Dutson (2005) found no inflows from Dixie Hot Springs downstream from the location of site T2. Thus, the inflow downstream from that point likely comes from shallow groundwater downstream (west) of the Hurricane Fault. The baseline bromide concentration at sites T2 and VR-3 was essentially the same, suggesting that water from the inflow downstream from $\mathrm{T} 2$ did not have the same composition as water from Dixie Hot Springs and does not add significantly to the dissolved-solids load at site VR-3.

\section{Dissolved-Solids Concentrations and Loads}

Dissolved-solids concentrations were measured in a water sample collected from Dixie Hot Springs and in water samples collected from the Virgin River upstream and downstream of the reach containing Dixie Hot Springs (sites VR-2 and VR-3) during this study (table 3). Most samples were analyzed for dissolved-solids concentrations as residue on evaporation at $180^{\circ} \mathrm{C}(\mathrm{ROE})$; in some samples, dissolved-solids concentrations were calculated as the sum of constituents, which consisted mostly of major ions and alkalinity. Specificconductance measurements associated with samples from sites VR-2 and VR-3 were regressed against ROE values, and the resulting regression equation (shown on fig. 8) was used to calculate dissolved-solids concentrations in water samples where only measurements of specific conductance were available. Specific conductance was measured on February 17, 2010, at seven discrete locations where discharge from Dixie Hot Springs was observed (table 5 and fig. 2). Dissolvedsolids concentrations calculated from these values of specific conductance using the regression equation ranged from 7,960 to $9,670 \mathrm{mg} / \mathrm{L}$ and averaged $9,250 \mathrm{mg} / \mathrm{L}$ (table 5).

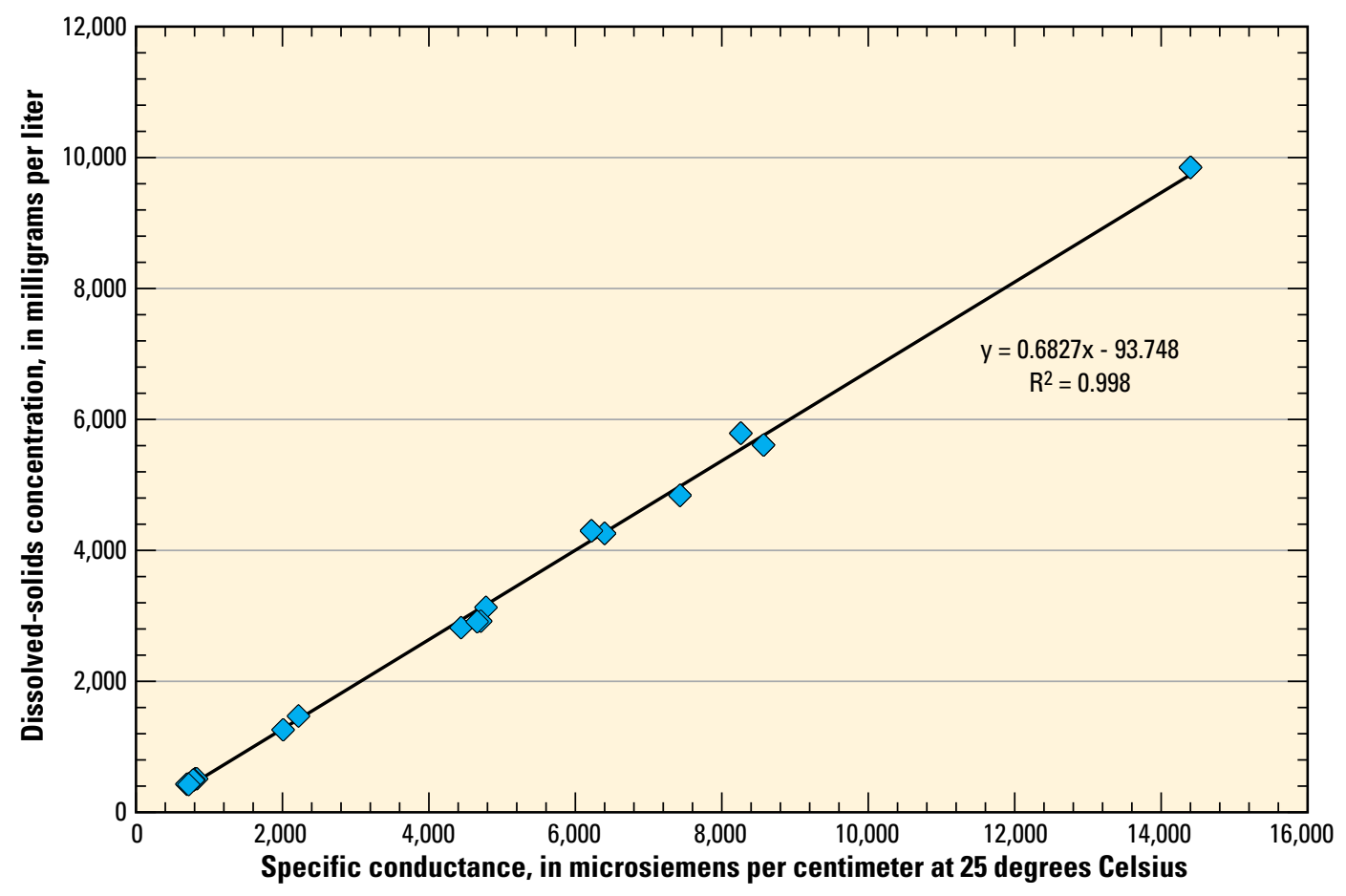

Figure 8. Relation of dissolved-solids concentration (measured as residue on evaporation at 180 degrees Celsius) to specific conductance in the Virgin River at sites VR-2 (upstream) and VR-3 (downstream) of Dixie Hot Springs, Utah. 
Table 5. Specific conductance (with calculated dissolved-solids concentrations) of groundwater from selected discharge points for Dixie Hot Springs, Utah, on February 17, 2010.

\begin{tabular}{|c|c|c|c|c|c|}
\hline $\begin{array}{l}\text { Figure } 2 \text { map } \\
\text { number }\end{array}$ & Site description & $\begin{array}{c}\text { Specific } \\
\text { conductance } \\
\left(\mu \mathrm{S} / \mathrm{cm} \text { at } 25^{\circ} \mathrm{C}\right)\end{array}$ & $\begin{array}{l}\text { Dissolved-solids } \\
\text { concentration } \\
\text { (mg/L) }\end{array}$ & $\begin{array}{c}\text { Water } \\
\text { temperature } \\
\left({ }^{\circ} \mathrm{C}\right)\end{array}$ & Remarks \\
\hline 1 & Outflow from 6 inch pipe & 14,300 & 9,670 & 40.6 & $\begin{array}{l}\text { Located on the right bank, at concrete control just } \\
\text { downstream from the first pipeline crossing }\end{array}$ \\
\hline 2 & Seep & 12,800 & 8,640 & 27.0 & $\begin{array}{l}\text { Located on the right bank, approximately } 100 \text { feet } \\
\text { downstream from the concrete control }\end{array}$ \\
\hline 3 & Small spring & 11,800 & 7,960 & 37.6 & $\begin{array}{l}\text { Located on the left bank at base of the cliff upstream } \\
\text { of grotto }\end{array}$ \\
\hline 4 & Seep & 14,000 & 9,460 & 37.1 & $\begin{array}{l}\text { Located on the right bank, in sand and gravel, ap- } \\
\text { proximately } 250 \text { feet downstream from the upper } \\
\text { pipeline crossing }\end{array}$ \\
\hline 5 & Spring & 14,300 & 9,670 & 41.1 & $\begin{array}{l}\text { Located on the left bank, discharge estimated at } \\
\text { about } 1 \text { cubic foot per second from cliff base, ap- } \\
\text { proximately } 75 \text { feet upstream of grotto }\end{array}$ \\
\hline 6 & Seep & 14,300 & 9,670 & 39.6 & Located on the right bank, across from grotto \\
\hline \multirow[t]{4}{*}{7} & Grotto outflow & 14,300 & 9,670 & 39.0 & Grotto, main outflow \\
\hline & Average & 13,700 & 9,250 & 37.4 & - \\
\hline & Standard deviation & 966 & 681 & 4.8 & - \\
\hline & 95-percent confidence & \pm 738 & \pm 505 & \pm 3.6 & - \\
\hline
\end{tabular}

${ }^{1}$ Dissolved-solids concentration was calculated from specific-conductance measurements as $\mathrm{C}=\mathrm{SC} * 0.6827-93.748$, where $\mathrm{C}$ is dissolved-solids concentration and SC is specific conductance.

Dissolved-solids loads discharged from Dixie Hot Springs were calculated using discharge measured in the Virgin River at sites upstream and downstream from the springs and dissolved-solids concentrations in river water at those sites. As for discharge described previously in this chapter, dissolvedsolids loads were determined with the area-velocity, stagedischarge, and slug tracer-injection methods. Dissolved-solids load was calculated from the following equation:

$$
L=Q * C * 0.9851
$$

where

$L \quad$ is dissolved-solids load, in tons per year;

$C$ is the dissolved-solids concentration in water, in milligrams per liter;

$Q \quad$ is discharge, in cubic feet per second; and

0.9851 is the factor used to convert from milligrams per liter and cubic feet per second to tons per year.

Paired measurements of discharge made on February 5, 2010, using the area-velocity method and dissolved-solids concentration at sites VR-2 and VR-3, were used to determine dissolved-solids load in the Virgin River and the load contributed by Dixie Hot Springs (table 4). For each pair of measurements, discharge and load at site VR-2 were subtracted from discharge and load at site VR-3 to determine discharge and load from Dixie Hot Springs. The load equation (2) was then rearranged as $C=L /(Q * 0.9851)$ and used to compute dissolved-solids concentration in water from Dixie Hot Springs (table 2). Loads contributed by Dixie Hot Springs to the Virgin River calculated from paired measurements of discharge and dissolved solids with this method were 87,400 and 98,900 ton/yr for two times on February 5, 2010 (tables 2 and 4).

Stage and specific conductance in the Virgin River were measured and recorded at 15-minute intervals at sites VR-2 and VR-3 during February 16-18, 2010. Of the almost 2,300 specific-conductance values recorded at each site during this period, only 900 from each were used in the calculation of dissolved-solids concentration and load discharged from Dixie Hot Springs. This subset of values represents those periods, on February 16 and 17, when the stage was in a range that allowed for discharge computation and discharge was stable or gently declining or increasing (fig. 4). Periods of rapid increase or decrease in discharge were excluded from the subset because abnormally large or small dissolved-solids load values occur during these short term events. Dissolved-solids concentrations were calculated from the subset of specificconductance data using the equation shown on figure 8. Dissolved-solids load was then calculated for each of these data points using discharge calculated from the stream-discharge relation. The average load was determined for the upstream 
and downstream sites on the Virgin River. A dissolved-solids load from Dixie Hot Springs of about 99,300 ton/yr is the difference between the average load at sites VR-2 and VR-3 determined with the stage-discharge method (tables 2 and 4).

A slug tracer-injection test on February 17, 2010, determined a net change in discharge between sites VR-2 and VR-3 of $11.8 \mathrm{ft}^{3} / \mathrm{s}$. The dissolved-solids concentration used for each site in the load equation was calculated from the average specific conductance measured at each site during the test. A dissolved-solids load from Dixie Hot Springs of about $102,500 \mathrm{ton} / \mathrm{yr}$ is the difference between the average load at sites VR-2 and VR-3 determined with the slug tracer-injection method (tables 2 and 4).

\section{Summary}

Dixie Hot Springs are a major point source of dissolved solids to the Virgin River. During 1972-81 and 1983-84, Reclamation studied the discharge of dissolved solids from Dixie Hot Springs, the transport of these salts in the Virgin River, and the feasibility of removing these salts from the river. Further interest in the removal of these salts has resulted in the need for verification of the discharge and annual dissolvedsolids load contributed to the Virgin River from Dixie Hot Springs.

To estimate the annual discharge of dissolved solids (dissolved-solids load) from Dixie Hot Springs to the Virgin River, discharge, specific conductance, and concentrations of major ions and dissolved solids were measured several times during 2009-10. Discharge from the springs was determined by measuring discharge in the Virgin River upstream and downstream of the springs using the area-velocity or tracerinjection method and then subtracting the upstream discharge from the downstream discharge. Similarly, the stage-discharge relation in the Virgin River upstream and downstream of the springs was established and used to calculate discharge from the springs. For data collected during this study (2009-10), the average measured discharge from Dixie Hot Springs was $11.0 \mathrm{ft}^{3} / \mathrm{s}$ (with an associated 95-percent confidence interval of 9.2-12.8 $\mathrm{ft}^{3} / \mathrm{s}$ ), the average dissolved-solids concentration was $9,210 \mathrm{mg} / \mathrm{L}$ (with an associated 95-percent confidence interval of 7,700-10,700 $\mathrm{mg} / \mathrm{L}$ ), and the average dissolved-solids load was 96,200 ton/yr (with an associated 95-percent confidence interval of 90,900-101,500 ton/yr; table 4).

Estimates of dissolved-solids load from Dixie Hot Springs associated with historical discharge measurements or estimates and dissolved-solids concentrations range from 87,400 to 139,300 ton/yr (table 2). Discharge and dissolved-solids concentrations from Dixie Hot Springs were most variable during 1985-94, a period that included the effects of sinkholes along the Virgin River and construction in and near Timpoweap Canyon that was related to the Quail Creek pipeline. Discharge from the hot springs in October 1985 increased to an estimated $20 \mathrm{ft}^{3} / \mathrm{s}$ (Everitt and Einert, 1994), dissolved-solids concentration decreased to an estimated 7,070 $\mathrm{mg} / \mathrm{L}$, and dissolvedsolids load increased to 139,300 ton/yr .

Estimates of average discharge, dissolved-solids concentration, and dissolved-solids load from Dixie Hot Springs that are based on all available measurements except data from $1985-94$ are $10.9 \mathrm{ft}^{3} / \mathrm{s}$ for discharge, $9,250 \mathrm{mg} / \mathrm{L}$ for dissolvedsolids concentration, and 98,900 ton/yr for dissolved-solids load. These averages include the historical data and data collected during the present study (values from 1960-82 and 1995-2010, table 2) and agree closely with the averages determined from data collected during 2009-10 as part of the present study. 


\section{References Cited}

Blackett, R.E., 1994, Low-temperature thermal water in Utah-A compilation of data for thermal wells and springs through 1993: Utah Geological Survey Open-File Report 311 , variously paginated.

Budding, K.E., and Sommer, S.N., 1986, Low-temperature geothermal assessment of the Santa Clara and Virgin Valleys, Washington County, Utah: Utah Geological and Mineral Survey Special Studies 67, 34 p.

Bureau of Reclamation, 1973, La Verkin Springs Unit, UtahFeasibility report: Colorado River Water Quality Improvement Program, Point Source Division, July 1973, Appendix A-Water Supply, 99 p.

Cole, D.R., 1983, Chemical and isotopic investigations of warms springs associated with normal faults in Utah: Journal of Volcanology and Geothermal Research, v. 16, p. 65-98.

Dutson, S.J., 2005, Effects of Hurricane Fault architecture on groundwater flow in the Timpoweap Canyon of southwestern Utah: Provo, Utah, Brigham Young University, Master of Science Thesis, $57 \mathrm{p}$.

Everitt, Ben, and Einert, Martin, 1994, The 1985 slug test of Pah Tempe Springs, Washington County, Utah, in Blackett, R.E., and Moore, J.N., eds., Cenozoic geology and geothermal systems of southwestern Utah: Utah Geological Association Publication 23, p. 189-194.
Kilpatrick, F.A., and Cobb, E.D., 1985, Measurement of discharge using tracers: U.S. Geological Survey Techniques of Water-Resources Investigations, book 3, chap. A16, 27 p.

Milligan, J.H., Marsell, R.E., and Bagley, J.M., 1966, Mineralized springs in Utah and their effect on manageable water supplies: Utah State University, Utah Water Research Laboratory Report WG23-6, 50 p., accessed on April 30, 2013, at http://digitalcommons.usu.edu/water_rep/196.

Mundorf, J.C., 1970, Major thermal springs of Utah: Utah Department of Natural Resources, Utah Geological and Mineral Survey Water Resources Bulletin 13, 60 p.

Rantz, S.E., and others, 1982, Measurement and computation of streamflow-Volume 1. Measurement of stage and discharge. Volume 2. Computation of discharge: U.S. Geological Survey Water-Supply Paper 2175, 631 p.

Sandberg, G.W., and Sultz, L.G., 1985, Reconnaissance of the quality of surface water in the upper Virgin River Basin, Utah, Arizona, and Nevada, 1981-82: Utah Department of Natural Resources Technical Publication no. 83, 69 p.

Winter, T.C., Harvey, J.W., Franke, O.L., and Alley, W.M., 1998, Ground water and surface water: A single resource: U.S. Geological Survey Circular 1139, 79 p.

Yelkin, M.A., 1996, Trace element analysis of selected springs in the Virgin River Basin: Las Vegas, Nev., University of Nevada, Master of Science Thesis, 155 p. 


\title{
Chapter 3. Dissolved-Solids Loads Estimated at Selected Sites in the Virgin River Basin
}

\author{
By Steven J. Gerner and Terry A. Kenney
}

Parts of this study use an accounting of discharge and dissolved-solids load at selected sites on the Virgin River between Virgin, Utah, and Lake Mead, Nevada. To provide an updated accounting, annual dissolved-solids loads were estimated at 13 monitoring sites in the Virgin River Basin (fig. 1). At 12 USGS gaging stations, estimates of annual loads depended on the availability of daily mean streamflow values and discrete measurements of dissolved-solids concentrations and (or) specific conductance (table 6). Annual dissolvedsolids loads for the St. George Regional Water Reclamation Facility (SGWRF) were provided by the City of St. George
Water Services Department (Ben Ford, written commun., 2011), and average annual discharge was determined from values provided by the Utah Division of Water Rights (Nathan Kennard, written commun., July 20, 2012). Seven of the 13 monitoring sites had the data needed to estimate annual dissolved-solids loads for WYs 1992 through 2010, while 6 stations had between 4 and 12 years of data. A discrete measurement of dissolved-solids concentration and specific conductance is listed in table 1 for water from each of the 12 USGS gaging stations.

Table 6. Summary of available dissolved-solids load calibration data for U.S. Geological Survey stream-gaging stations in the Virgin River Basin for water years 1992 through 2010, and Load Estimator (LOADEST) model descriptive statistics.

[Site number, U.S. Geological Survey downstream order number; Site name, site identifier used in this study; Regression terms: b, natural log of discharge; c, natural log of discharge squared; d, seasonality term A; e, seasonality term B; f, decimal time; g, decimal time squared; <, less than]

\begin{tabular}{|c|c|c|c|c|c|c|c|c|c|c|}
\hline Site number & Site name & Site description & $\begin{array}{l}\text { Number of } \\
\text { available } \\
\text { dissolved- } \\
\text { solids con- } \\
\text { centration } \\
\text { measure- } \\
\text { ments } \\
\end{array}$ & $\begin{array}{l}\text { Number of pairs of } \\
\text { dissolved-solids } \\
\text { concentration } \\
\text { and daily mean } \\
\text { streamflow values } \\
\text { used to calibrate } \\
\text { load models }\end{array}$ & $\begin{array}{l}\text { Period of } \\
\text { available } \\
\text { dissolved- } \\
\text { solids model } \\
\text { calibration } \\
\text { data }\end{array}$ & $\begin{array}{c}\text { Regression } \\
\text { terms } \\
\text { included in } \\
\text { the best-fit } \\
\text { model }\end{array}$ & $\begin{array}{c}R^{2} \text { of } \\
\text { regression }\end{array}$ & $\begin{array}{c}\text { Estimated } \\
\text { residual } \\
\text { variance }\end{array}$ & $\begin{array}{l}\text { Serial } \\
\text { correla- } \\
\text { tion of the } \\
\text { residuals }\end{array}$ & $\begin{array}{c}\text { Turnbull- } \\
\text { Weiss } \\
\text { normal- } \\
\text { ity test } \\
\text { statistic }\end{array}$ \\
\hline 09406000 & VR-1 & Virgin River at Virgin, Utah & 65 & 93 & $1992-2010$ & b,c,d,e,f,g & 94.6 & 0.011 & -0.03 & 29.8 \\
\hline 09406100 & VR-4 & $\begin{array}{l}\text { Virgin River above La Verkin } \\
\text { Creek, near La Verkin, Utah }\end{array}$ & 5 & ${ }^{1} 1,475$ & $2005-2010$ & b,c,d,e,f,g & 79.4 & 0.017 & 0.58 & 513.5 \\
\hline 09408135 & VR-5 & $\begin{array}{l}\text { Virgin River above Quail } \\
\text { Creek, near Hurricane, Utah }\end{array}$ & 6 & 15 & $\begin{array}{l}1993 \\
2005-2010\end{array}$ & $\mathrm{~b}$ & 79.8 & 0.013 & -0.16 & 0.7 \\
\hline 09408150 & VR-6 & $\begin{array}{l}\text { Virgin River near Hurricane, } \\
\text { Utah }\end{array}$ & ${ }^{2} 71$ & 121 & $1992-2010$ & $\mathrm{~b}, \mathrm{c}, \mathrm{d}, \mathrm{e}, \mathrm{f}$ & 80.5 & 0.054 & 0.09 & 64.7 \\
\hline 09408195 & FPW & $\begin{array}{l}\text { Fort Pearce Wash near } \\
\text { St. George, Utah }\end{array}$ & ${ }^{2} 34$ & 34 & $2002-2010$ & $\mathrm{~b}, \mathrm{~d}, \mathrm{e}$ & 87.1 & 0.125 & 0.21 & 2.4 \\
\hline 09413000 & SCR & $\begin{array}{l}\text { Santa Clara River at } \\
\text { St. George, Utah }\end{array}$ & ${ }^{2} 106$ & 149 & $1992-2010$ & $\mathrm{~b}, \mathrm{c}, \mathrm{d}, \mathrm{e}, \mathrm{f}$ & 96.6 & 0.030 & 0.14 & 17.8 \\
\hline 09413200 & VR-7 & $\begin{array}{l}\text { Virgin River near Bloomington, } \\
\text { Utah }\end{array}$ & ${ }^{3} 26$ & 90 & $1992-2010$ & $\mathrm{~b}, \mathrm{~d}, \mathrm{e}$ & 91.3 & 0.049 & -0.16 & 22.7 \\
\hline 09413500 & VR-8 & $\begin{array}{l}\text { Virgin River near Utah/Arizona } \\
\text { State line, Utah }\end{array}$ & ${ }^{2} 133$ & 152 & $1992-2010$ & $\mathrm{~b}, \mathrm{c}, \mathrm{d}, \mathrm{e}, \mathrm{f}, \mathrm{g}$ & 96.9 & 0.016 & 0.11 & 39.3 \\
\hline 09413700 & VR-14 & $\begin{array}{l}\text { Virgin River above the Nar- } \\
\text { rows, near Littlefield, Arizona }\end{array}$ & 2 & ${ }^{4} 63$ & $1999-2010$ & $\mathrm{~b}, \mathrm{c}, \mathrm{d}, \mathrm{e}, \mathrm{f}, \mathrm{g}$ & 98.5 & 0.017 & 0.02 & 16.6 \\
\hline 09414900 & BDW & $\begin{array}{l}\text { Beaver Dam Wash at Beaver } \\
\text { Dam, Arizona }\end{array}$ & 9 & 10 & $2009-2010$ & b,c,d,e,f,g & 100.0 & $<.001$ & -0.46 & 3.3 \\
\hline 09415000 & VR-15 & $\begin{array}{l}\text { Virgin River at Littlefield, } \\
\text { Arizona }\end{array}$ & 93 & 101 & $1992-2010$ & b,c,d,e,f,g & 96.7 & 0.007 & 0.14 & 31.4 \\
\hline 09415250 & VR-16 & $\begin{array}{l}\text { Virgin River above Lake Mead, } \\
\text { Nevada }\end{array}$ & 14 & 14 & $2007-2010$ & b,c,d,e,f,g & 99.9 & 0.004 & -0.06 & 2.4 \\
\hline
\end{tabular}

${ }^{1}$ Daily mean specific-conductance values available.

${ }^{2}$ Includes data from the Utah Department of Environmental Quality.

${ }^{3}$ Includes data from the U.S. Environmental Protection Agency's Storage and Retrieval (STORET) Data Warehouse

${ }^{4}$ Used specific conductance and dissolved-solids concentration relation from site number 09413500 (site VR-8). 


\section{Methods of Estimating Dissolved-Solids Loads}

Annual dissolved-solids loads for the 12 USGS gaging stations were derived from analyses of dissolved-solids concentrations, specific-conductance measurements, daily mean streamflow computations, and statistical modeling. Because daily mean streamflow determined for a station rarely has a daily dissolved-solids concentration available to calculate load, annual loads for each station were estimated using the Load Estimator (LOADEST) computer program (Runkel and others, 2004). The S-LOADEST version (David Lorenz, U.S. Geological Survey, written commun., 2005) was used for this study, which is LOADEST embedded into the statistical software package Spotfire S+ (Tibco Software, Inc., 1998-2008). Individual load models for each station were constructed with S-LOADEST using data pairs of dissolved-solids concentrations and daily mean streamflow (table 6). Most of the dissolved-solids concentration values used to calibrate the load models were from water samples collected by the USGS and the Utah Department of Environmental Quality (UDEQ). These data were obtained from the USGS NWIS database (U.S. Geological Survey, 2011) and the U.S. Environmental Protection Agency Storage and Retrieval (STORET) Data Warehouse (U.S. Environmental Protection Agency, 2011). The number of available dissolved-solids concentration measurements ranged from as many as 133 at site VR- 8 to less than 10 at four stations (table 6).

For some gaging stations where few dissolved-solids concentration measurements were available, specific-conductance values in the NWIS and STORET databases were used to estimate dissolved-solids concentrations for use in the S-LOADEST models. A relation between pairs of measured dissolved-solids concentration and measured specific conductance at each site was developed so that dissolved-solids concentrations could be estimated from specific-conductance measurements. Site VR-4 was instrumented with a specific conductance probe and data logger from which 1,475 daily mean specific-conductance values and, therefore, dissolvedsolids concentration values were computed.

Dissolved-solids load models for each gaging station were obtained using the "best model" option in S-LOADEST. S-LOADEST contains nine load-model formulations that were examined using dissolved-solids concentrations and streamflow data for each station. Additional terms used in the regression equations are based on selected functions of streamflow, seasonality, and time. The output regression equations that relate load to the explanatory variables take the following general form:

$$
\begin{aligned}
& \ln (L)=a+b(\ln Q)+c\left(\ln Q^{2}\right)+d[\sin (2 T)]+ \\
& e[\cos (2 T)]+f T+g T^{2}
\end{aligned}
$$

where
$L \quad$ is the estimated dissolved-solid load, in tons per day;
$a$ is the regression equation intercept;
$Q \quad$ is streamflow, in cubic feet per second;

$T \quad$ is decimal time used in determinations of
annual and seasonal (2T) variability; and

$b, c, d, e, f$, and $g$ are regression coefficients.

Some of the regression equations did not include all of the above terms, depending on the particular model chosen by the software. A complete discussion of the theory and principles behind calibration and estimation methods used by the LOADEST software is given by Runkel and others (2004).

Statistical diagnostics and plots associated with the models selected by S-LOADEST were examined for each station to ensure that assumptions embedded in the models related to normality and multicolinearity in the data and residuals were not violated. Custom models, incorporating time and (or) seasonal terms, as well as other types of variable transformations, were attempted in an effort to construct better load-prediction models. However, the S-LOADEST software-selected models proved to be the best load-prediction models for dissolved solids for all stations; thus, the software-selected models were used to compute the annual dissolved-solids loads for the years of complete daily mean streamflow data at each station.

\section{Annual Dissolved-Solids Loads}

Annual dissolved-solids loads estimated at sites in the Virgin River during water years 1992-2010 varied spatially and temporally (table 7). Along the Virgin River in the study area, the smallest annual dissolved-solids loads were at site VR-1, the Virgin River at Virgin, Utah, upstream of Dixie Hot Springs. The largest annual loads were at site VR-15, the Virgin River at Littlefield, Arizona, downstream of Littlefield Springs. Annual dissolved-solids loads at most of the gaging stations were smallest during 2002, a year with below normal precipitation. The smallest total annual flow on record (19512010) in the Virgin River near the Utah/Arizona State line (site VR-8) was in 2002 (Wilkowske and others, 2003). Loads were largest during 2005, a year that included a winter rain storm that resulted in flooding throughout much of the Virgin River Basin. The largest total annual flow on record (1951-2010) at site VR-8 was in 2005 (Wilkowske and others, 2006). The average annual loads at the 13 sites for the period 2007-10 are shown in figure 9. This period is used in the following discussion because it is the longest period for which each site has a complete set of annual dissolved-solid load estimates. However, the average annual dissolved-solids load is strongly dependent on the period being considered. For example, at site VR-7, the average annual dissolved-solids loads for the periods 2007-10, 2002-10, and 1992-2010 are 179,300; 206,400; and 232,600 tons, respectively (table 7). The inclusion of the wet year 2005 in the latter two periods results in substantially larger average annual loads. Appendix 1 lists selected statistics for the estimated dissolved-solids loads modeled for the 12 stream-gaging stations.

Average annual dissolved-solids loads in the Virgin River mostly increase along the river from site VR-1, near the river's headwaters, to site VR-16 near its terminus at Lake Mead, 
Nevada. Downstream from site VR-1, a substantial portion of the water and dissolved solids (and therefore the dissolvedsolids load) in the Virgin River is diverted to the Quail Creek pipeline at the Quail Creek diversion dam (fig. 1). Some of this diverted water is conveyed to the La Verkin and Hurricane areas for irrigation, some is returned to the river after use at a hydropower plant, and some is conveyed to Sand Hollow Reservoir, or to Quail Creek Reservoir. Annual loads in the river increase substantially from site VR-1 to site VR-4 due to the addition of dissolved solids in inflow from Dixie Hot Springs. Because of flow alterations to the river associated with irrigation diversions and reservoir management, the difference in dissolved-solids loads determined for 2007-10 at sites VR-1 and VR-4 (69,500 ton/yr) is less than the simple addition of the 2009-10 average dissolved-solids load from Dixie Hot Springs (96,200 ton/yr, table 4), which was determined primarily from measurements made in February 2010.

Relatively dilute inflow from tributary streams, including Ash and La Verkin Creeks, between sites VR-4 and VR-5 increase the mean daily streamflow in the Virgin River, but do not cause a large increase in dissolved-solids load. Water that is returned to the Virgin River from the Quail Creek Reservoir, between sites VR-5 and VR-6, to meet the St. George and Washington Canal (SGWC) water right also dilutes the dissolved-solids concentration in the Virgin River downstream of Dixie Hot Springs. Thus, there is little change in dissolvedsolid load between sites VR-4 and VR-6.

A large portion of the water and dissolved solids in the Virgin River is diverted into the SGWC at the diversion dam near Washington, Utah (fig. 1). Dissolved solids are added to the river in runoff from the irrigated acreage served by the canal. Additional salts are dissolved from the soil and rock underlying this and other agricultural areas in the Virgin River Basin by excess irrigation water (water applied in excess of crop needs) that has percolated into the subsurface. These dissolved solids are transported in groundwater that discharges from seeps and drains to the Virgin River. The average dissolved-solids load increases by 48,300 ton/yr in the river reach between sites VR-6 and VR-7 because of dissolved solids in inflow from Fort Pearce Wash (site FPW), the Santa Clara River (site SCR), and agricultural drains near St. George and Washington (fig. 1). The addition of dissolved-solids loads from sites FPW (3,720 ton/yr) and SCR (17,700 ton/yr) accounts for less than half of the river's increase in load. Much of the remaining increase in load is likely from agriculturaldrain discharge to this reach of the Virgin River. Streamflow from Fort Pearce Wash to the Virgin River is naturally ephemeral and flow from the Santa Clara River is highly regulated, resulting in periods with no inflow to the Virgin River from these subbasins downstream of St. George, Utah. However, dissolved solids are added to the Virgin River from these streams when they do flow.

Dissolved solids in outflow from the SGWRF increases the average dissolved-solids load in the Virgin River from 179,300 ton/yr at site VR-7 near Bloomington, Utah, to 190,400 ton/yr at site VR-8 near the Utah/Arizona State line.
Treated water discharged from the SGWRF contributes an average dissolved-solids load of 14,600 ton/yr to the Virgin River just downstream of site VR-7. This contribution is larger than the increase in average load between the two river sites, VR-7 and VR-8 (11,100 ton/yr). There are minor seepage losses of water and dissolved solids from the river to the groundwater system in the reach between sites VR-7 and VR-8 (see chapter 4) that may account for some of the difference between the reported average load from the SGWRF $(14,600 \mathrm{ton} / \mathrm{yr})$ and the increase in load between the two river sites $(11,100$ ton/yr).

The Virgin River flows into the Virgin River Gorge near the Utah/Arizona State line and loses some water and dissolved solids through seepage from the river channel to the groundwater system as the river crosses several fault zones in the upper part of the gorge (see chapter 4). A decrease in average dissolved-solids load of 42,000 ton/yr is calculated between site VR-8 and site VR-14 above the Narrows in the Virgin River Gorge, Arizona.

Inflow of water and dissolved solids from Littlefield Springs to the Virgin River is the main component of a substantial increase in average dissolved-solids load (136,500 ton/yr) between sites VR-14 and VR-15. Littlefield Springs are a complex of springs and seeps near the downstream end of the Virgin River Gorge, just below the Narrows and upstream of Littlefield, Arizona (see chapter 5). Some water and dissolved solids are added to the Virgin River in ephemeral runoff from Beaver Dam Wash and runoff from the Beaver Dam and Virgin Mountains. The dissolved-solids load added to this reach of the river from these sources is small relative to Littlefield Springs; the Beaver Dam Wash (site BDW) was estimated to contribute an average load of only 957 ton/yr.

In the lower part of the Virgin River Basin, from near the mouth of the Virgin River Gorge in Arizona (site VR-15) to near Lake Mead in Nevada (site VR-16), water is diverted from the river for agricultural and municipal uses (primarily near the towns of Littlefield, Arizona, and Mesquite, Bunkerville, and Riverside, Nevada). This results in an average decrease in dissolved-solids load of 25,900 ton/yr between sites VR-15 and VR-16. Most of the dissolved solids diverted from the river probably return to the river in excess irrigation water and groundwater seepage; however, the transport of dissolved solids in the lower Virgin River Basin is not well documented. Dissolved solids stored in soils in the agricultural areas could be flushed to the river during periods of increased precipitation (such as the large rain storm in 2005). Additionally, an estimated 70,000 acre-ft/yr (Cole and Katzer, 2000) of water is lost from the Virgin River between sites VR-15 and VR-16 through evapotranspiration. Evapotranspiration removes the water, but not the dissolved solids, resulting in an increased dissolved-solids concentration. The Virgin River finally discharges its load of dissolved solids (an average of 259,000 ton/yr at site VR-16) to Lake Mead, a major source of water used for irrigation and public supply, on the lower Colorado River. 
Table 7. Annual dissolved-solids loads estimated at 12 U.S. Geological Survey stream-gaging stations and reported for the St. George Regional Water Reclamation Facility, Virgin River Basin, and annual daily mean streamflow.

[Site number, U.S. Geological Survey downstream order number; Site name, site identifier used in this study; —, no data; NA, not applicable; see Appendix 1 for selected statistics of dissolved-solids load]

\begin{tabular}{|c|c|c|c|c|c|c|c|c|c|c|c|c|c|c|}
\hline $\begin{array}{c}\begin{array}{c}\text { Site number } \\
\text { Site name }\end{array} \\
\text { Site description } \\
\end{array}$ & \multicolumn{2}{|c|}{$\begin{array}{c}09406000 \\
\text { VR-1 }\end{array}$} & \multicolumn{2}{|c|}{$\begin{array}{c}09406100 \\
\text { VR-4 }\end{array}$} & \multicolumn{2}{|c|}{$\begin{array}{c}09408135 \\
\text { VR-5 }\end{array}$} & \multicolumn{2}{|c|}{$\begin{array}{c}09408150 \\
\text { VR-6 }\end{array}$} & \multicolumn{2}{|c|}{$\begin{array}{c}09408195 \\
\text { FPW }\end{array}$} & \multicolumn{2}{|c|}{$\begin{array}{c}09413000 \\
\text { SCR }\end{array}$} & \multicolumn{2}{|c|}{$\begin{array}{c}\text { 09413200 } \\
\text { VR-7 }\end{array}$} \\
\hline & \multicolumn{14}{|c|}{ Annual dissolved-solids load (Load), in tons per year, and annual daily mean streamflow (0), in cubic feet per second } \\
\hline Water year & Load & Q & Load & Q & Load & Q & Load & Q & Load & Q & Load & Q & Load & Q \\
\hline 1992 & 64,700 & 137 & - & - & - & - & 114,300 & 149 & - & - & 7,680 & 8.2 & 205,900 & 145 \\
\hline 1994 & 64,900 & 140 & - & - & - & - & 179,600 & 157 & - & - & 9,620 & 7.4 & 218,000 & 148 \\
\hline 1995 & 94,400 & 300 & - & - & - & - & 226,400 & 342 & - & - & 24,200 & 53 & 381,500 & 401 \\
\hline 1996 & 54,600 & 115 & - & - & - & - & 157,900 & 127 & - & - & 8,510 & 5.3 & 181,900 & 115 \\
\hline 1997 & 62,800 & 151 & - & - & - & - & 163,500 & 152 & - & - & 10,300 & 7.6 & 212,700 & 151 \\
\hline 1998 & 84,600 & 262 & - & - & - & - & 214,000 & 288 & - & - & 25,400 & 36 & 341,900 & 331 \\
\hline 2002 & 41,200 & 85 & - & - & - & - & 110,900 & 72 & 336 & 0.2 & 5,210 & 2.3 & 120,100 & 58 \\
\hline 2003 & 48,500 & 107 & - & - & - & - & 107,200 & 72 & 9,260 & 6.4 & 5,150 & 2.2 & 120,400 & 62 \\
\hline 2004 & 48,400 & 107 & - & - & - & - & 119,700 & 82 & 4,120 & 2.8 & 6,340 & 2.8 & 121,200 & 61 \\
\hline 2005 & 113,100 & 524 & - & - & 201,700 & 713 & 229,400 & 715 & 7,510 & 6.9 & 59,300 & 117 & 540,100 & 759 \\
\hline 2006 & 64,600 & 166 & 142,200 & 107 & 136,600 & 138 & 167,400 & 169 & 3,320 & 2.2 & 26,700 & 19 & 238,300 & 176 \\
\hline 2007 & 49,400 & 110 & 122,900 & 67 & 120,400 & 82 & 123,700 & 91 & 1,300 & 0.8 & 11,000 & 5.4 & 157,700 & 89 \\
\hline 2008 & 55,900 & 132 & 125,200 & 74 & 123,700 & 94 & 128,700 & 103 & 12,300 & 8.6 & 18,000 & 9.2 & 173,800 & 104 \\
\hline 2009 & 55,500 & 128 & 120,300 & 68 & 121,500 & 83 & 124,500 & 92 & 161 & 0.1 & 22,800 & 15 & 169,400 & 99 \\
\hline 2010 & 67,400 & 180 & 137,600 & 112 & 137,500 & 146 & 147,200 & 148 & 1,140 & 0.7 & 19,000 & 10 & 216,300 & 160 \\
\hline $\begin{array}{l}2002-10 \\
\text { average }\end{array}$ & 60,400 & 171 & NA & NA & NA & NA & 139,900 & 172 & 4,380 & 3.2 & 19,300 & 20 & 206,400 & 174 \\
\hline $\begin{array}{l}2007-10 \\
\text { average }\end{array}$ & 57,000 & 137 & 126,500 & 80 & 125,800 & 101 & 131,000 & 109 & 3,720 & 2.5 & 17,700 & 10 & 179,300 & 113 \\
\hline
\end{tabular}


Table 7. Annual dissolved-solids loads estimated at 12 U.S. Geological Survey stream-gaging stations and reported for the St. George Regional Water Reclamation Facility, Virgin River Basin, and annual daily mean streamflow. - Continued

[Site number, U.S. Geological Survey downstream order number; Site name, site identifier used in this study; -, no data; NA, not applicable; see Appendix 1 for selected statistics of dissolved-solids load]

\begin{tabular}{|c|c|c|c|c|c|c|c|c|c|c|c|c|}
\hline \multirow{2}{*}{$\begin{array}{c}\begin{array}{c}\text { Site number } \\
\text { Site name }\end{array} \\
\text { Site description }\end{array}$} & \multicolumn{2}{|c|}{$\begin{array}{c}\text { NA } \\
\text { SGWRF }\end{array}$} & \multicolumn{2}{|c|}{$\begin{array}{c}09413500 \\
\text { VR-8 }\end{array}$} & \multicolumn{2}{|c|}{$\begin{array}{c}09413700 \\
\text { VR-14 }\end{array}$} & \multicolumn{2}{|c|}{$\begin{array}{c}09414900 \\
\text { BDW }\end{array}$} & \multicolumn{2}{|c|}{$\begin{array}{c}09415000 \\
\text { VR-15 }\end{array}$} & \multicolumn{2}{|c|}{$\begin{array}{c}09415250 \\
\text { VR-16 }\end{array}$} \\
\hline & \multicolumn{2}{|c|}{$\begin{array}{c}\text { St. George Regional } \\
\text { Water Reclamation } \\
\text { Facility }\end{array}$} & \multicolumn{2}{|c|}{$\begin{array}{c}\text { Virgin River near Utah/ } \\
\text { Arizona } \\
\text { State line, Utah }\end{array}$} & \multicolumn{2}{|c|}{$\begin{array}{l}\text { Virgin River above } \\
\text { the Narrows, near } \\
\text { Littlefield, Arizona }\end{array}$} & \multicolumn{2}{|c|}{$\begin{array}{l}\text { Beaver Dam Wash at } \\
\text { Beaver Dam, Arizona }\end{array}$} & \multicolumn{2}{|c|}{$\begin{array}{c}\text { Virgin River at } \\
\text { Littlefield, Arizona }\end{array}$} & \multicolumn{2}{|c|}{$\begin{array}{c}\text { Virgin River above } \\
\text { Lake Mead, near } \\
\text { Overton, Nevada }\end{array}$} \\
\hline \multicolumn{13}{|c|}{ Annual dissolved-solids load (Load), in tons per year, and annual daily mean streamflow (0), in cubic feet per second } \\
\hline Water year & Load & Q & Load & Q & Load & Q & Load & $\mathrm{Q}$ & Load & Q & Load & $\mathrm{Q}$ \\
\hline 1993 & 11,100 & 9.0 & 352,400 & 472 & - & - & - & - & 497,300 & 594 & - & - \\
\hline 1994 & 11,200 & 8.9 & 220,100 & 154 & - & - & - & - & 318,300 & 183 & - & - \\
\hline 1995 & 12,200 & 10 & 335,700 & 402 & - & - & - & - & 463,700 & 493 & - & - \\
\hline 1996 & 12,700 & 10 & 174,500 & 113 & - & - & - & - & 290,400 & 164 & - & - \\
\hline 1997 & 13,800 & 11 & 215,200 & 170 & - & - & - & - & 321,400 & 211 & - & - \\
\hline 1999 & 13,100 & 11 & 220,700 & 155 & 183,200 & 129 & - & - & 323,200 & 192 & - & - \\
\hline 2000 & 12,000 & 11 & 171,200 & 109 & 138,600 & 88 & - & - & 268,800 & 147 & - & - \\
\hline 2001 & 11,700 & 11 & 191,300 & 129 & 150,800 & 95 & - & - & 272,300 & 149 & - & - \\
\hline 2002 & 11,900 & 11 & 119,500 & 62 & 93,200 & 46 & - & - & 214,100 & 103 & - & - \\
\hline 2003 & 12,300 & 11 & 129,000 & 75 & 107,000 & 55 & - & - & 226,400 & 116 & - & - \\
\hline 2004 & 13,000 & 11 & 137,200 & 75 & 109,300 & 56 & - & - & 228,200 & 113 & - & - \\
\hline 2005 & 15,200 & 13 & 413,600 & 735 & 404,200 & 639 & - & - & 548,800 & 825 & - & - \\
\hline 2006 & 14,900 & 13 & 229,800 & 171 & 201,200 & 140 & 497 & 4.6 & 356,800 & 233 & - & - \\
\hline 2007 & 14,500 & 14 & 167,600 & 97 & 129,100 & 68 & 722 & 3.5 & 259,500 & 133 & 293,300 & 96 \\
\hline 2008 & 14,700 & 14 & 183,400 & 107 & 139,700 & 79 & 705 & 2.3 & 291,000 & 158 & 262,400 & 121 \\
\hline 2009 & 14,200 & 14 & 180,900 & 100 & 132,900 & 72 & 1,010 & 2.8 & 256,000 & 125 & 219,300 & 108 \\
\hline Average & Load & Q & Load & Q & Load & Q & Load & Q & Load & Q & Load & $\mathrm{Q}$ \\
\hline $\begin{array}{l}\text { Average for } \\
\text { years with } \\
\text { data during } \\
1992-2010\end{array}$ & 12,900 & 11 & 219,600 & 198 & 165,100 & 134 & 865 & 3.4 & 327,600 & 248 & 259,000 & 124 \\
\hline $\begin{array}{l}\text { 1999-2010 } \\
\text { average }\end{array}$ & 13,500 & 12 & 197,800 & 164 & 165,100 & 134 & NA & NA & 298,200 & 208 & NA & NA \\
\hline $\begin{array}{l}\text { 1999-2010 } \\
\text { average } \\
\text { (excluding } \\
\text { years 2002 } \\
\text { and 2005) }\end{array}$ & 13,500 & 12 & 184,100 & 118 & 148,400 & 93 & NA & NA & 281,500 & 157 & NA & NA \\
\hline $\begin{array}{l}2002-10 \\
\text { average }\end{array}$ & 13,900 & 13 & 199,000 & 176 & 167,600 & 144 & NA & NA & 301,500 & 224 & NA & NA \\
\hline $\begin{array}{l}2007-10 \\
\text { average }\end{array}$ & 14,600 & 14 & 190,400 & 116 & 148,400 & 91 & 957 & 3.1 & 284,900 & 156 & 259,000 & 124 \\
\hline
\end{tabular}




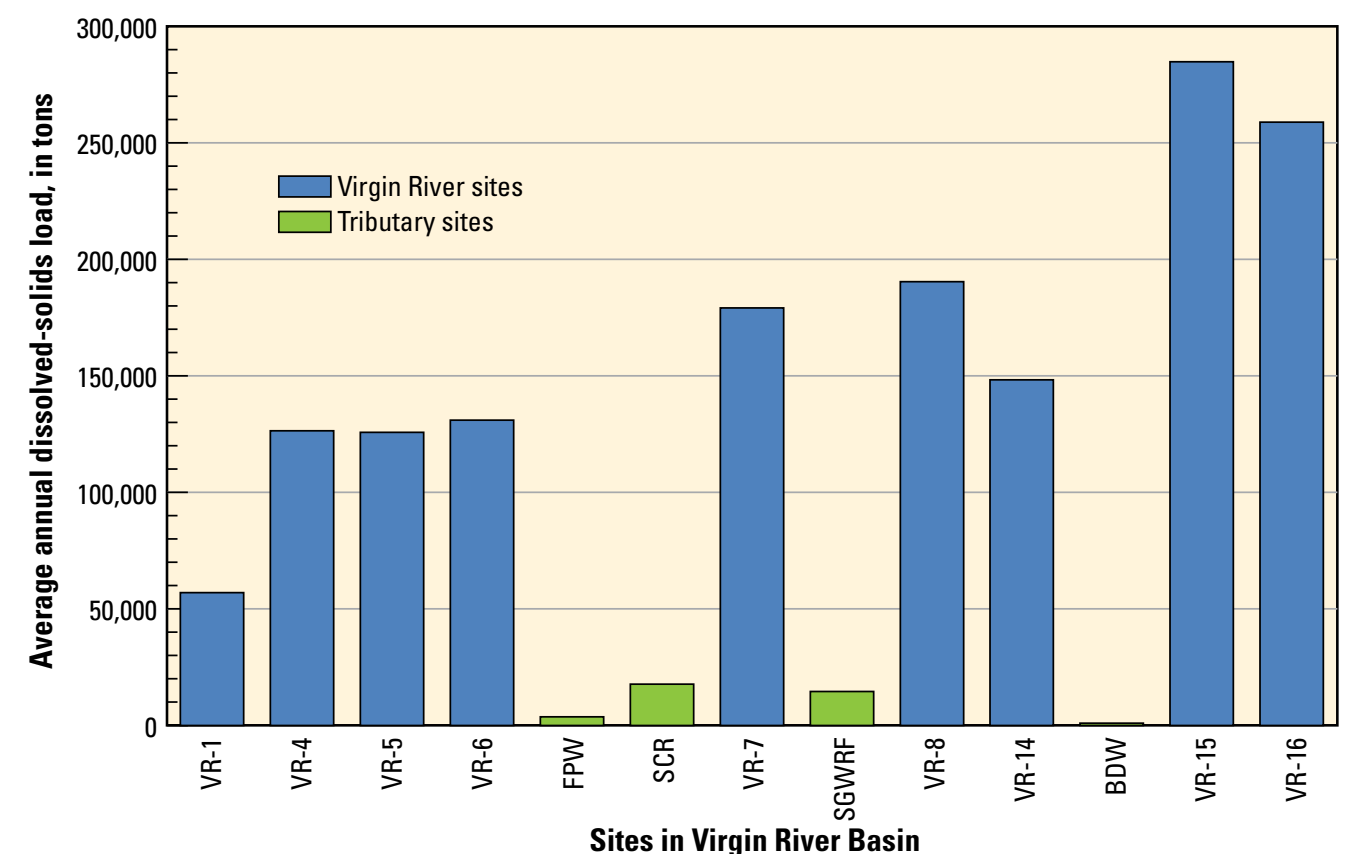

Figure 9. Average annual dissolved-solids load at selected sites in the Virgin River Basin, water years 2007-10. See table 7 for site descriptions and average annual loads determined for other years.

\section{Summary}

Parts of this study use an accounting of discharge and dissolved-solids load at selected sites on the Virgin River between Virgin, Utah and Lake Mead, Nevada. To provide an updated accounting, annual dissolved-solids loads were estimated at 13 monitoring sites in the Virgin River Basin for varying periods of time during water years 1992-2010. At the 12 USGS gaging stations, estimates of annual loads depended on the availability of daily mean streamflow values and discrete measurements of dissolved-solids concentrations and (or) specific conductance, which limited calculations of dissolvedsolids loads at 6 of these sites to 12 or fewer years. Annual dissolved-solids loads for the St. George Regional Water Reclamation Facility were provided by the City of St. George Water Services Department.

Annual dissolved-solids loads estimated at sites in the Virgin River during water years 1992-2010 varied spatially and temporally. Along the Virgin River in the study area, the smallest annual dissolved-solids loads were in the Virgin River at Virgin, Utah, upstream of Dixie Hot Springs (average load of 57,000 ton/yr during 2007-10). The largest annual loads were in the Virgin River at Littlefield, Arizona (average load of 284,900 ton/yr during 2007-10), downstream of Littlefield Springs. Average annual dissolved-solids loads in the Virgin River mostly increase as the river flows from near the town of Virgin, Utah, downstream to its terminus at Lake Mead, Nevada. Groundwater discharge and several tributaries contribute water and dissolved solids to the Virgin River, but the largest increase in dissolved-solids concentration occurs between sites upstream and downstream of Dixie Hot Springs and of Littlefield Springs. Substantial portions of the water and dissolved solids (and therefore the dissolved-solids load) in the Virgin River are diverted to the Quail Creek pipeline and the St. George and Washington Canal upstream of St. George and are lost through streambed seepage in the Virgin River Gorge.

\section{References Cited}

Runkel, R.L., Crawford, C.G., and Cohn, T.A., 2004, Load Estimator (LOADEST): A FORTRAN program for estimating constituent loads in streams and rivers: U.S. Geological Survey Techniques of Water-Resources Investigations, book 4, chap. A5, 69 p.

TIBCO Software, Inc., 1998-2008, Spotfire S+ Release 8.1, Somerville, Mass.

U.S. Environmental Protection Agency, 2011, Modernized Storage and Retrieval (STORET) Data Warehouse, accessed January 10, 2011 at http://www.epa.gov/storet/dw_home. html.

U.S. Geological Survey, 2011, National Water Information System (NWISWeb): U.S. Geological Survey database, accessed June 10, 2011, at http://waterdata.usgs.gov/nwis.

Wilkowske, C.D., Allen, D.V., and Phillips, J.V., 2003, Drought conditions in Utah during 1999-2002: A historical perspective: U.S. Geological Survey Fact Sheet 037-03, 6 p.

Wilkowske, C.D., Kenney, T.A., and McKinney, T.S., 2006, Flooding and streamflow in Utah during water year 2005: U.S. Geological Survey Fact Sheet 2006-3085, 6 p. 


\section{Chapter 4. Streamflow Losses in the Virgin River Between Bloomington, Utah, and the Virgin River Gorge Narrows, Arizona}

\section{By Steven J. Gerner}

The Virgin River loses flow between Bloomington, Utah (site VR-7), and the Narrows of the Virgin River Gorge, Arizona (site VR-14), mostly through riverbed seepage to the underlying groundwater system. These losses are of interest to the Colorado River Basin Salinity Control Program and Virgin River water managers because the losses may influence the amount and timing of economic benefits associated with proposed salinity-control projects in the Virgin River Basin. Several investigators, particularly Trudeau and others (1983) and Cole and Katzer (2000), have documented historical discharge measurements made between 1952 and 1976 that indicated a streamflow loss of between 10 and $108 \mathrm{ft}^{3} / \mathrm{s}$ from the Virgin River in the reach from approximately Bloomington, Utah, to the Utah/Arizona State line. Cole and Katzer (2000) studied flow in this reach of the river during 1998-99 and found that there was no loss at that time. They concluded that the losses previously reported may have resulted from streamflow infiltration to the groundwater system through the underlying carbonate rock, as evidenced by sinkholes in Big Round Valley about 1 mi upstream of the State line (fig. 10). Cole and Katzer (2000) did not offer a specific reason why the river was no longer losing water in this manner, but it is possible that lateral shifting of the channel had resulted in less exposure to the sinkholes and thus, less infiltration of Virgin River streamflow.

Flow in the Virgin River between the USGS stream-gaging station near the Utah/Arizona State line (VR-8) and the gaging station above the Narrows near Littlefield, Arizona (VR-14), is intermittent during most years. Cole and Katzer (2000) measured an average streamflow loss of about $27 \mathrm{ft}^{3} / \mathrm{s}$ in this reach of the river. Evapotranspiration contributes to streamflow losses in this reach, but most of the losses result from seepage into the streambed. Much of this seepage is theorized to follow flow paths defined by fault zones until the seepage ultimately discharges in the general vicinity of the Virgin River Narrows, particularly through Littlefield Springs (Cole and Katzer, 2000). For this study, historical streamflow data from USGS gaging stations at sites VR-7, VR-8, and VR-14, along with instantaneous discharge measurements in the reach between sites VR-8 and VR-14, were used to determine losses in flow from the Virgin River.

\section{Streamflow Losses Determined from Monthly Streamflow Data}

The Virgin River between Bloomington, Utah, and the mouth of the Virgin River Gorge has a shifting sand channel that makes it difficult to accurately measure streamflow by means of a stage-discharge relation. The daily mean streamflow records determined for gaging stations on this reach of the river are generally rated "fair," meaning that 95 percent of the values are judged to be within 15 percent of the true value. An analysis of the change (gain or loss) in streamflow in this reach of the river was conducted using paired values of monthly average streamflow for sites VR-7 and VR-8, and for sites VR-8 and VR-14. The streamflow data were obtained from the USGS NWIS database. Streamflow gains or losses within this reach of the Virgin River were calculated from differences in monthly average flow between these pairs of sites. Very large monthly gains in streamflow relative to most months were determined to be outliers - probably the result of runoff from localized storms, poor definition of stagedischarge relations for large flows, or problems with estimated streamflow records. Consequently, monthly average streamflow values greater than the 90th percentile $(387,383$, and $215 \mathrm{ft}^{3} / \mathrm{s}$ for sites VR-7, VR-8 and VR-14, respectively) were removed from the dataset, as were the gains calculated from these values.

Analysis of monthly average flow in the river between sites VR-7 and VR-8 indicated that upstream diversions from the Virgin River for irrigation have a substantial influence on apparent streamflow gains and losses in the reach. As a result, changes in streamflow in this reach were determined only for those months (October-March) when diversions from the river for irrigation were minimal. In addition, because the SGWRF outflow occurs downstream of site VR-7, its average discharge for the month was added to the monthly average streamflow at VR-7 prior to calculating monthly streamflow differences between sites VR-7 and VR-8. Based on these criteria, 101 paired monthly values from October 1991 to March 2010 were used to determine an average streamflow loss of $6.7 \pm 3.0 \mathrm{ft}^{3} / \mathrm{s}$ ( \pm 95 -percent confidence) from the Virgin River between sites VR-7 (near Bloomington, Utah) and VR-8 (just upstream of the Utah/Arizona State line; fig. 11). The average of monthly flows at site VR-7 combined with outflow from SGWRF used in this analysis was $157 \mathrm{ft}^{3} / \mathrm{s}$. Changes in flow within the 95-percent confidence interval for the average change in this reach (a loss of 3.7 to $9.7 \mathrm{ft}^{3} / \mathrm{s}$ ) generally fall within the rated error of the monthly streamflow ( \pm 15 percent). Thus, the calculated gains and losses for this reach should be used with caution. 


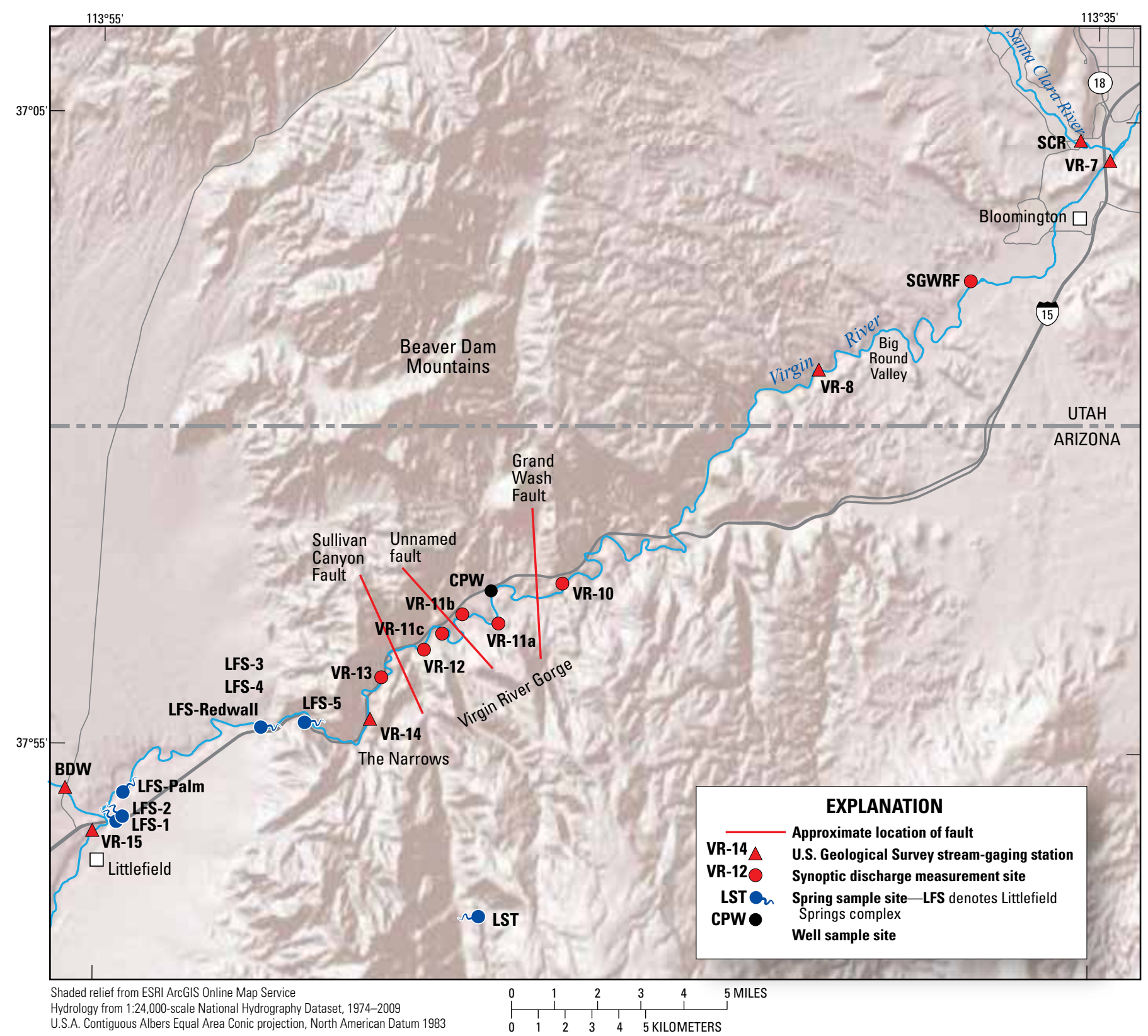

Figure 10. Stream-gaging stations, sites near faults where synoptic discharge measurements were made to determine seepage losses from the Virgin River in August 2010, and sampled groundwater sites in and near the Virgin River Gorge, Utah and Arizona.

An average streamflow loss was calculated for the Virgin River from upstream of the Utah/Arizona State line to above the Narrows of the Virgin River Gorge using monthly average streamflow at sites VR-8 and VR-14. As for the upstream reach between sites VR-7 and VR-8, monthly average streamflow values greater than the 90th percentile were removed from the dataset as were the gains calculated from these values. Additionally, differences in discharge between VR-8 and VR-14 were not included for those months in which the average streamflow at VR-8 was less than $40 \mathrm{ft}^{3} / \mathrm{s}$. This exclusion is applied because, when the monthly average streamflow at site VR- 8 is less than $40 \mathrm{ft}^{3} / \mathrm{s}$, it is likely that there were days during that month when there was no flow at site VR-14, which would cause the calculated losses in the reach to be biased low. Based on these criteria, 114 paired monthly values from July 1998 to September 2010 were used to determine an average streamflow loss of $26.7 \pm 2.9 \mathrm{ft}^{3} / \mathrm{s}( \pm 95$-percent confidence) from the Virgin River between sites VR-8 (just upstream of the Utah/Arizona State line) and VR-14 (above the Narrows in Arizona; fig. 11). The average of monthly flows at site VR-8 used in this analysis is $116 \mathrm{ft}^{3} / \mathrm{s}$. Streamflow losses within the 95-percent confidence interval for the average change in this reach (a loss of 23.8 to $29.6 \mathrm{ft}^{3} / \mathrm{s}$ ) are considerably larger than the rated error of the reported streamflow 


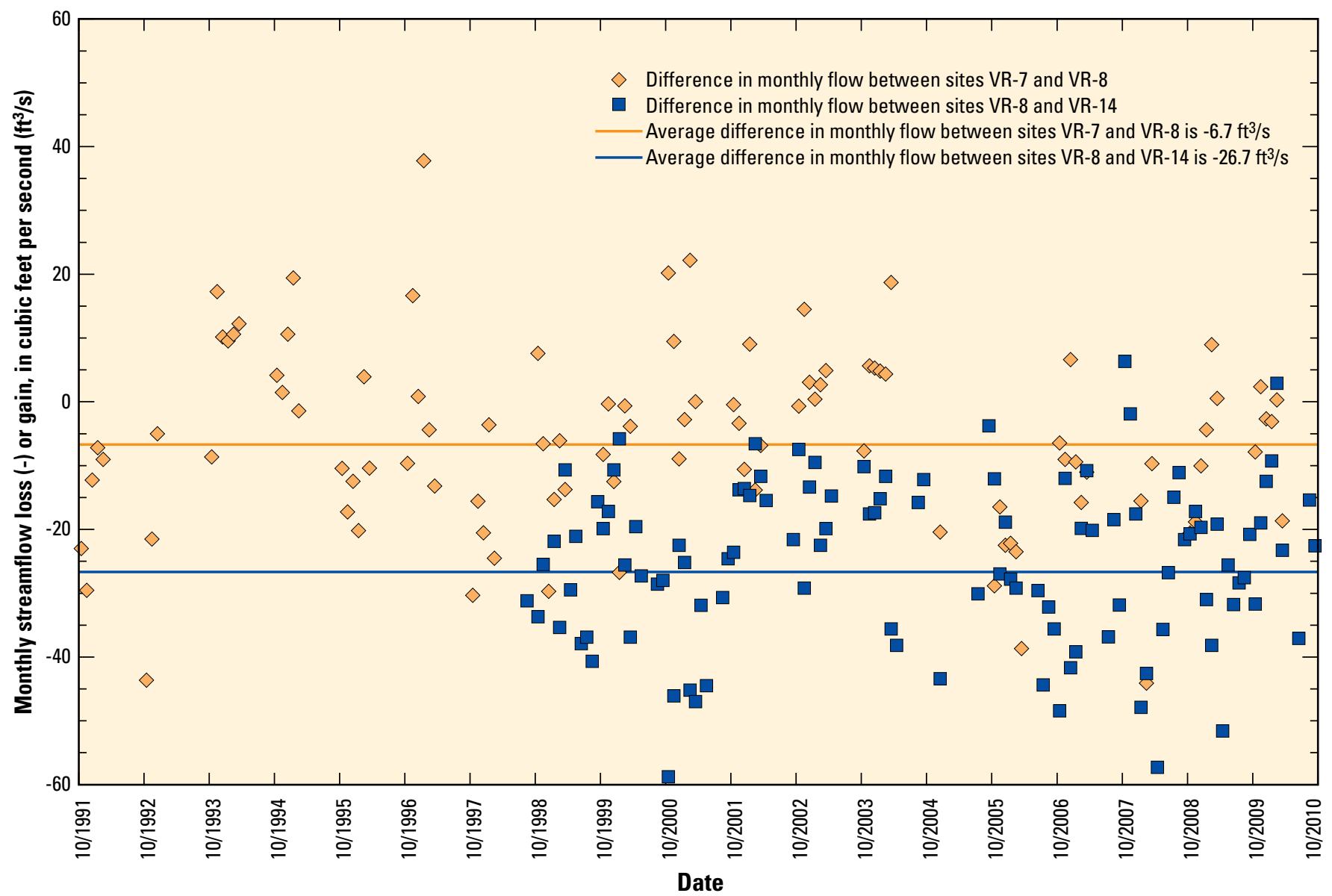

Figure 11. Monthly streamflow loss or gain in the Virgin River between sites VR-7 and VR-8 and between sites VR-8 and VR-14.

( \pm 15 percent). Monthly changes in streamflow in the Virgin River between sites VR-8 and VR-14 used in this analysis ranged from a net gain of $6.3 \mathrm{ft}^{3} / \mathrm{s}$ to a net loss of $87.1 \mathrm{ft}^{3} / \mathrm{s}$. Possible causes for the large range in streamflow gains and losses calculated for the reach include unaccounted losses from evapotranspiration, runoff from precipitation occurring between the sites, and (or) poor discharge records.

\section{Streamflow Losses Determined from Synoptic Discharge Measurements}

The hypothesis that substantial flow and dissolved-solids load are lost through seepage into fault zones underlying the Virgin River in the Virgin River Gorge was tested using synoptic measurements of discharge. Discharge measurements were made using hand-held acoustic Doppler velocimeters and standard USGS stream-gaging techniques (Rantz and others, 1982; U.S. Geological Survey, 2007). Paired measurements of stream discharge were made upstream and downstream of three areas with faults (fig. 10) on August 11 and 12, 2010, to determine seepage loss in three reaches of the Virgin River. During this period, streamflow in the Virgin River was slowly decreasing from higher flows that occurred as the result of rainfall on August 9, 2010. However, based on changes in stage measured at temporary reference points at the measurement sites, streamflow in the Virgin River was fairly steady during each of the pairs of synoptic measurements so that a meaningful comparison of upstream and downstream flow was possible.

Losses determined from synoptic measurements of flow in the Virgin River in three reaches with identified faults were $3.1,3.4$, and $2.4 \mathrm{ft}^{3} / \mathrm{s}$, for a total seepage loss of $8.9 \mathrm{ft}^{3} / \mathrm{s}$ (table 8). The seepage loss measured in each short reach was compared to the average streamflow loss for the reach between the gaging stations upstream and downstream of the Virgin River Gorge, which was calculated from mean daily streamflow values for a 5-day period starting on August 12, 2010. Averaging streamflow loss over this time period minimized some of the error associated with the 9-hour traveltime between sites VR-8 and VR-14 and with the general decrease in flow that occurred during the synoptic measurements. From the continuous monitoring of flow in the Virgin River at sites VR-8 and VR-14 during this period, it was determined that an average of $18.4 \mathrm{ft}^{3} / \mathrm{s}$ was lost (table 8 ).

An aggregate length of $4 \mathrm{mi}$ for the reaches bracketed by synoptic measurements in the vicinity of the faults is about 25 percent of the length of the reach bounded by sites VR-8 
and VR-14 (16.2 mi). However, seepage in the vicinity of these faults accounts for 48 percent of the average loss in streamflow in the reach bounded by sites VR-8 and VR-14, indicating an association between seepage loss and fault zones rather than a homogenous loss of flow throughout the reach.

The streamflow losses shown in table 8 between sites bracketing a fault is about 6 percent of the upstream discharge measurement. The uncertainty calculated for individual instantaneous measurements is generally 2-4 percent of the measured streamflow. Because the differences in streamflow are larger than the uncertainty of the measurements, it can be assumed that the losses in flow are real.

\section{Summary}

The Virgin River loses flow between Bloomington, Utah (site VR-7), and the Narrows of the Virgin River Gorge, Arizona (site VR-14), mostly through riverbed seepage to the underlying groundwater system. These losses are of interest to the Colorado River Basin Salinity Control Program and Virgin River water managers because the losses may influence the amount and timing of economic benefits associated with proposed salinity-control projects in the Virgin River Basin.

Analysis of monthly average discharge in the Virgin River between sites VR-7 and VR-8 (just upstream of the Utah/Arizona State line) showed an average streamflow loss of $6.7 \pm 3.0 \mathrm{ft}^{3} / \mathrm{s}$ ( \pm 95 -percent confidence). Changes in flow within the 95-percent confidence interval for the average change in this reach (a loss of 3.7 to $9.7 \mathrm{ft}^{3} / \mathrm{s}$ ) generally fall within the rated error of the monthly streamflow values ( \pm 15 percent). Thus, the calculated gains and losses for this reach should be used with caution. An average streamflow loss of $26.7 \pm 2.9 \mathrm{ft}^{3} / \mathrm{s}$ was calculated for the Virgin River from just upstream of the Utah/Arizona State line to above the Narrows of the Virgin River Gorge using monthly average streamflow at sites VR-8 and VR-14. Streamflow losses within the 95-percent confidence interval for the average change in this reach (a loss of 23.8 to $29.6 \mathrm{ft}^{3} / \mathrm{s}$ ) are considerably larger than the rated error of the reported streamflow ( \pm 15 percent).

From continuous monitoring of flow in the Virgin River at sites VR-8 and VR-14 during August 12-16, 2010, it was determined that an average of $18.4 \mathrm{ft}^{3} / \mathrm{s}$ was lost in the reach from just upstream of the Utah/Arizona State line to above the Narrows of the Virgin River Gorge during this period. Also during this period, synoptic measurements of stream discharge showed that streamflow losses in the vicinity of selected faults accounted for 48 percent of the average loss in streamflow in the reach bounded by sites VR-8 and VR-14. This large percentage of loss occurring near the faults indicates an association between seepage loss and fault zones rather than a homogenous loss of flow throughout the reach.

\section{References Cited}

Cole, Erin, and Katzer, Terry, 2000, Analysis of gains and losses in Virgin River flow between Bloomington, Utah, and Littlefield, Arizona: Las Vegas., Nev., Southern Nevada Water Authority, $57 \mathrm{p}$.

Rantz, S.E., and others, 1982, Measurement and computation of streamflow-Volume 1. Measurement of stage and discharge. Volume 2. Computation of discharge: U.S. Geological Survey Water-Supply Paper 2175, $631 \mathrm{p}$.

Trudeau, D.A., Hess, J.W., and Jacobson, R.L., 1983, Hydrology of the Littlefield Springs, Arizona: Ground Water, v. 21, no. 3, p. 325-333.

U.S. Geological Survey, 2007, SonTek/YSI Flowtracker firmware version 2.11 upgrades and additional policy on the use of FlowTrackers for discharge measurements: U.S. Geological Survey, Office of Surface Water Technical Memorandum 2007.01, unpaged, accessed August 1, 2010, at http://water. usgs.gov/admin/memo/SW/sw07.01.html.

Table 8. Synoptic discharge measurements used to determine streamflow losses in the Virgin River in and near the Virgin River Gorge, August 2010.

[Loss in discharge for a site is calculated relative to discharge at the site immediately upstream, except for site VR-14, where the loss in discharge is calculated relative to discharge at site VR-8. - , not applicable]

\begin{tabular}{|c|c|c|c|c|c|c|c|}
\hline $\begin{array}{l}\text { Site name } \\
\text { (shown on } \\
\text { figure 10) }\end{array}$ & $\begin{array}{l}\text { Description of upstream and downstream sites } \\
\text { for reaches on the Virgin River }\end{array}$ & Date & Time & $\begin{array}{l}\text { Instantaneous } \\
\text { discharge } \\
\text { (cubic feet per } \\
\text { second) }\end{array}$ & $\begin{array}{l}\text { Daily mean } \\
\text { discharge } \\
\text { (cubic feet per } \\
\text { second) }\end{array}$ & $\begin{array}{l}\text { Loss in discharge } \\
\text { (cubic feet per } \\
\text { second) }\end{array}$ & $\begin{array}{l}\text { Percentage of loss } \\
\text { in reach relative to } \\
\text { loss in reach from } \\
\text { VR-8 to VR-14 }\end{array}$ \\
\hline VR-10 & Upstream of Grand Wash Fault & $8 / 12 / 2010$ & $11: 40$ & 52.9 & - & - & - \\
\hline VR-11a & Downstream of Grand Wash Fault & $8 / 12 / 2010$ & $13: 00$ & 49.8 & - & 3.1 & 17 \\
\hline VR-11b & Upstream of unnamed fault & $8 / 11 / 2010$ & $12: 00$ & 71.0 & - & - & - \\
\hline VR-11c & Downstream of unnamed fault & $8 / 11 / 2010$ & $13: 20$ & 67.6 & - & 3.4 & 18 \\
\hline VR-12 & Upstream of Sullivan Canyon Fault & $8 / 12 / 2010$ & $08: 20$ & 54.2 & - & - & - \\
\hline VR-13 & Downstream of Sullivan Canyon Fault & $8 / 12 / 2010$ & $09: 25$ & 51.8 & - & 2.4 & 13 \\
\hline VR-8 & Near Utah/Arizona State line & $8 / 12-16 / 2010$ & - & - & 50.8 & - & - \\
\hline VR-14 & Above the Virgin River Gorge Narrows & $8 / 12-16 / 2010$ & - & - & 32.4 & 18.4 & 100 \\
\hline
\end{tabular}




\title{
Chapter 5. Sources of Groundwater Discharge from Littlefield Springs in and near the Virgin River Gorge, Arizona
}

\author{
By Victor M. Heilweil, Donald S. Sweetkind, and Steven J. Gerner
}

\section{Littlefield Springs consist of over 200 individual springs} (Trudeau and others, 1983) that discharge along a 6-mi reach of the Virgin River within and downstream of the Virgin River Gorge in the northeast corner of Arizona (fig. 10). To determine the average discharge from Littlefield Springs, the monthly average streamflow of Beaver Dam Wash (BDW) and the Virgin River above the Narrows near Littlefield, Arizona (site VR-14) was subtracted from the monthly average streamflow of the Virgin River near Littlefield, Arizona (site VR-15), for each month during the period October 2000 to September 2005 (WYs 2001-05). The average discharge from Littlefield Springs during 2001-05 based on this method varied from 29 to $90 \mathrm{ft}^{3} / \mathrm{s}$ and averaged $56 \pm 2.6 \mathrm{ft}^{3} / \mathrm{s}$ (Steven Gerner, U.S. Geological Survey, written commun., 2008). This groundwater discharge is 36 percent of the average annual daily mean streamflow in the Virgin River at site VR-15 $\left(157 \mathrm{ft}^{3} / \mathrm{s}\right)$ for the period from 1999-2010, excluding 2002 and 2005. The dissolved-solids concentrations of groundwater samples from Littlefield Springs during 2009 and 2010 ranged from 2,660 to $2,880 \mathrm{mg} / \mathrm{L}$ (table 1 ), corresponding to a dissolved-solids load of about 154,000 ton/yr discharging to the Virgin River. The water discharging at Littlefield Springs originates at least in part as seepage from upstream reaches of the Virgin River; thus, understanding and quantifying the sources of the dissolved-solids load from Littlefield Springs are needed to better understand the effects of a hypothetical reduction in load that would be achieved by reducing dissolved-solids loads from Dixie Hot Springs to upstream reaches of the Virgin River.

\section{Sources of Groundwater Discharge from Littlefield Springs}

Geochemical and environmental tracer data from groundwater and surface-water sites in the Virgin River Gorge area, collected by Heilweil and others (2014) in an earlier phase of the present study, suggest that discharge from Littlefield Springs is a mixture of modern (post-1950s) seepage from the Virgin River upstream of Littlefield Springs and older groundwater discharging from a regional carbonate aquifer. The methods, data, and findings of Heilweil and others (2014) support the hypothesis described by
Trudeau and others (1983) that seepage losses from the Virgin River in and upstream of the Virgin River Gorge are a source of water discharging from Littlefield Springs. A summary of the findings of Heilweil and others (2014) is presented here.

Assuming that Littlefield Springs discharge is a binary mixture of two piston-flow components, the mixture is estimated to be about 60-percent seepage from the Virgin River and 40 percent from the regional carbonate aquifer (a 57:43 mixing ratio). Components of this binary mixture from Littlefield Springs are based on

- chloride/fluoride and chloride/bromide mass ratios that indicate 56- and 68-percent river water, respectively;

- a deuterium mass balance that indicates 67-percent river water and 33-percent groundwater from the regional carbonate aquifer; and

- concentrations of the chlorofluorocarbons (CFCs) CFC-12 and CFC-113 that indicate a mixture containing 57-percent river water.

Based on the 57:43 mixing ratio for river water and groundwater, $32 \mathrm{ft}^{3} / \mathrm{s}$ of the estimated discharge from Littlefield Springs were recharged as seepage from the Virgin River. This value is similar to the estimate of $33.4 \mathrm{ft}^{3} / \mathrm{s}$ of seepage loss

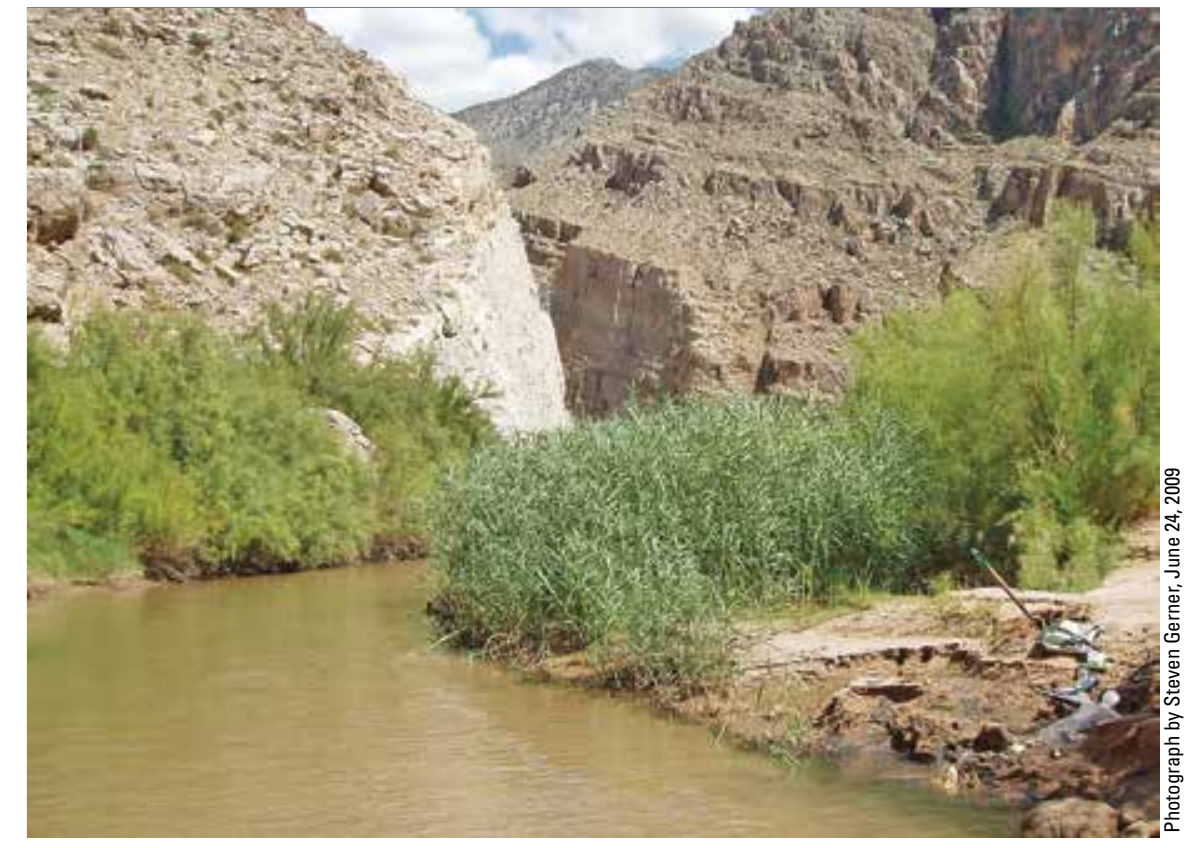

View of Virgin River looking upstream (to the east) in the Virgin River Gorge, Arizona, with groundwater discharging along the right bank at Littlefield Springs site LFS-5. 
from the river in the reach between sites VR-7 and VR-14, upstream of Littlefield Springs (chapter 4). Darcy calculations indicate that the majority of this seepage loss from the river travels through carbonate bedrock beneath alluvial deposits of the river channel.

Samples from Littlefield Springs show some evaporative enrichment of the stable-isotope ratios of the water molecule (deuterium, $\delta^{2} \mathrm{H}$, and oxygen-18, $\delta^{18} \mathrm{O}$ ). $\delta^{2} \mathrm{H}$ and $\delta^{18} \mathrm{O}$ values for the springs are consistent with a mixture of isotopically depleted, high-altitude recharge to the regional carbonate aquifer and evaporatively enriched Virgin River water. Calculated noble-gas recharge temperatures for Littlefield Springs discharge are generally cooler than the mean annual temperature of water in the Virgin River and are consistent with the relatively depleted stable-isotope concentrations. These findings indicate a high-altitude recharge source area for the regional carbonate aquifer (Heilweil and others, 2014).

CFC concentrations are consistent with tritium results and indicate that there is a modern (post-1950s) component to the discharging groundwater from Littlefield Springs. CFC ages of this modern component range from 24 to 29 years. Assuming that recharge occurs as seepage from the Virgin River, the average subsurface traveltime is about $26 \pm 1.6$ years between the area where the seepage occurs and discharge at Littlefield Springs (Heilweil and others, 2014).

Radiocarbon $\left({ }^{14} \mathrm{C}\right)$ and stable carbon $\left({ }^{13} \mathrm{C}\right)$ isotopes were used to evaluate the age of the older (greater than 1,000 years) groundwater in the Virgin River Gorge area. The lowest ${ }^{14} \mathrm{C}$ concentrations (activities) in the area were measured at Littlefield Springs; corrected ${ }^{14} \mathrm{C}$ ages of groundwater discharging at Littlefield Springs range from 1,000 to 9,000 years. Because the discharging groundwater at Littlefield Springs is a mixture of waters from different sources, the component that originates from the regional carbonate aquifer likely is much older than the groundwater ages suggested by the Littlefield Springs samples. Helium-isotope results indicate that the discharge from Littlefield Springs has a component of very old groundwater that may be tens of thousands of years old (Heilweil and others, 2014).

A Basin Characterization Model (BCM) of the Great Basin, mostly in Nevada and Utah, was used to estimate locations where precipitation infiltrates to and recharges the carbonate aquifer in the Virgin River Gorge drainage area (Flint and others, 2011). Results of the BCM indicate that the majority of infiltration occurs through permeable bedrock in the Clover and Bull Valley Mountains - about 30 to 50 mi north of the Virgin River Narrows - which are areas with higher average annual precipitation than in the nearby Virgin Mountains. The finding that recharge to the regional carbonate aquifer occurs in these areas is supported by hydrogeologic cross sections and potentiometric contours, which suggest that groundwater flows from north to south through permeable pathways in the carbonate aquifer rocks to the Virgin River Gorge area.

\section{Summary}

Littlefield Springs discharge an estimated $56 \mathrm{ft}^{3} / \mathrm{s}$ to the Virgin River and this discharge contains an annual load of about 154,000 tons of dissolved solids. Knowledge about the amount and age of Virgin River water in the discharge from Littlefield Springs is important when calculating the physical and economic effects of actions to control the salinity of Dixie Hot Springs. Geochemical and environmental tracer data from groundwater and surface-water sites in the Virgin River Gorge area indicate that groundwater discharge from Littlefield Springs is a mixture of about 60 percent modern (post-1950s) seepage from the Virgin River upstream of the springs and about 40 percent older groundwater discharging from a regional carbonate aquifer. This ratio suggests that about $34 \mathrm{ft}^{3} / \mathrm{s}$ of the estimated $56 \mathrm{ft}^{3} / \mathrm{s}$ discharged from Littlefield Springs is derived from the Virgin River, which is similar to the estimate of the present study of $33.4 \mathrm{ft}^{3} / \mathrm{s}$ for seepage loss from the Virgin River between sites VR-7 and VR-14 (see chapter 4). On the basis of these findings, a hypothetical removal of dissolved solids in water discharging from Dixie Hot Springs to the Virgin River would cause a reduction in the dissolved-solids load discharging from Littlefield Springs into the river within several decades.

\section{References Cited}

Flint, L.E., Flint, A.L., and Masbruch, M.D., 2011, Appendix 3: Input, calibration, uncertainty, and limitations of the Basin Characterization Model, in Heilweil, V.M., and Brooks, L.E., eds., Conceptual model of the Great Basin Carbonate and Alluvial Aquifer System: U.S. Geological Survey Scientific Investigations Report 2010-5193, p. 149-163.

Heilweil, V.M., Sweetkind, D.S., and Gerner, S.J., 2014, Innovative environmental tracer techniques for evaluating sources of spring discharge from a carbonate aquifer bisected by a river: Ground Water, v. 52, p. 71-83. doi: 10.111/gwat.12030.

Trudeau, D.A., Hess, J.W., and Jacobson, R.L., 1983, Hydrogeology of the Littlefield Springs, Arizona: Ground Water, v. 21 , no. 3, p. 325-333. 


\title{
Chapter 6. Hypothetical Changes to Dissolved-Solids Concentrations and Loads in Discharge from Irrigated Lands Following the Reduction of Dissolved- Solids Loads from Dixie Hot Springs to the Virgin River
}

\author{
By Briant A. Kimball and Steven J. Gerner
}

Inflow from Dixie Hot Springs contributes dissolved solids to Virgin River water that is subsequently diverted for irrigation in agricultural areas near St. George and Washington, Utah. If the discharge from Dixie Hot Springs were captured and treated to remove dissolved solids, the Virgin River water that is applied to agricultural fields would have a substantially lower dissolved-solids concentration. This change could affect the concentrations and loads of dissolved solids in water that leaves the irrigated agricultural land as excess irrigation water (which is returned to the Virgin River through drainage ditches) or as infiltrating recharge to the underlying groundwater system. Currently, the excess irrigation water that drains from the agricultural fields is even more concentrated in dissolved constituents than the Virgin River water as a result of evapotranspiration and the dissolution of efflorescent salt crusts at the land surface that were formed during the previous agricultural season. Some of the irrigation water applied to fields also infiltrates past the root zone and the level intercepted by the drainage ditches to become groundwater recharge. This groundwater can dissolve additional minerals as it moves through the sediment and underlying geologic formations.

\section{Changes in Dissolved Solids in Virgin River Water Used for Irrigation}

The effect of removing dissolved solids from Dixie Hot Springs on dissolved-solids loads from agricultural areas near St. George and Washington, Utah, which would result because of the reduced dissolved-solids content of Virgin River irrigation water, was investigated using a mass-balance approach. Water samples that represent three general groups were collected:

- group 1 samples representing potential irrigation water that does not contain dissolved solids from Dixie Hot Springs;

- group 2 samples representing the current (2014) irrigation water that does contain dissolved solids from Dixie Hot Springs; and

- group 3 samples from sources downgradient from agricultural areas, including ditches draining excess irrigation water and a groundwater sample from a well in an irrigated field.

The chemistry of the water samples representing these three groups is presented in table 9 .
There are substantial differences in dissolved constituent concentrations among the three groups. The potential irrigation water (group 1) is represented by three samples from the Virgin River collected upstream from the inflow of Dixie Hot Springs (site VR-1) and one sample from Quail Creek Reservoir, which is fed by water diverted from the river upstream of the hot springs. Each of these potential irrigation waters is a magnesium-bicarbonate/calcium-sulfate/sodium-chloride type water in terms of simple salts (fig. 12). The median dissolvedsolids concentration of these samples is $479 \mathrm{mg} / \mathrm{L}$. The chemical character of four samples representing water currently used for irrigation (group 2) is a sodium-chloride/calcium-sulfate/ magnesium-bicarbonate type water with a median dissolvedsolids concentration of $1,390 \mathrm{mg} / \mathrm{L}$. Water from group 2 includes inflow from Dixie Hot Springs to the Virgin River. Seven samples from agricultural drains and a well (group 3) have higher concentrations of all constituents (except potassium) than the other two groups. The chemical character of these post-irrigation samples evolves into a calcium-sulfate/ sodium-chloride/magnesium-bicarbonate type water with a median dissolved-solids concentration of 3,230 mg/L. One sample was selected from each group (table 9) for use in massbalance calculations.

The increase in dissolved-solids concentration $(1,680 \mathrm{mg} / \mathrm{L}$, table 10) between Virgin River water currently used for irrigation and the agricultural drain that discharges excess irrigation water from the soil was assumed to result mostly from the dissolution of efflorescent salts left on the irrigated fields from the previous irrigation season. The minerals that are most likely responsible for the increase in dissolved solids in excess irrigation water draining from the agricultural fields (table 11) were determined using the geochemical model SNORM (Bodine and Jones, 1986). SNORM computes the normative salt assemblage (salt norm) and the quantity of the minerals that would precipitate from fully evaporated water given the initial dissolved mineral composition of that water. Thus, SNORM can be used to determine the most likely efflorescent salts in the irrigated fields. The minerals dissolved from soils in agricultural areas that contribute the most to the increase in dissolved solids were halite (35.3 percent) and anhydrite (36.5 percent), which together equal 72 percent of the total mass transfer. Three other minerals contribute smaller percentages of the dissolved solids: magnesite (10.6 percent), bloedite (5.8 percent), and polyhalite ( 0.2 percent). These percentages were determined by using the minerals determined from 
Table 9. Chemical analysis of samples from the Virgin River, Quail Creek Reservoir, groundwater, and selected agricultural drains near St. George and Washington, Utah.

[Ca, calcium; $\mathrm{Mg}$, magnesium; $\mathrm{Na}$, sodium; $\mathrm{K}$, potassium; $\mathrm{Cl}$, chloride; $\mathrm{SO}_{4}$, sulfate; $\mathrm{HCO}_{3}$, bicarbonate; $\mathrm{SiO}$, silica; all concentrations are in milligrams per liter; $\mathrm{SC}$, specific conductance, in microsiemens per centimeter at 25 degrees Celsius]

\begin{tabular}{|c|c|c|c|c|c|c|c|c|c|c|}
\hline Site name ${ }^{1}$ (site type) & Date & Ca & Mg & $\mathrm{Na}$ & $\mathbf{K}$ & Cl & $\mathrm{SO}_{4}$ & $\mathrm{HCO}_{3}$ & $\mathrm{SiO}_{2}$ & SC \\
\hline \multicolumn{11}{|c|}{ Potential irrigation water without dissolved solids from Dixie Hot Springs } \\
\hline VR-1 (river) & $8 / 20 / 2002$ & 64.4 & 28 & 57.7 & 4.4 & 67.4 & 155 & 185 & 9.9 & 810 \\
\hline VR-12 (river) & $6 / 29 / 2009$ & 57.9 & 26.8 & 48.5 & 3.5 & 57.7 & 136 & 180 & 9.8 & 741 \\
\hline VR-1 (river) & $4 / 20 / 2010$ & 54.4 & 17.7 & 15.6 & 2.5 & 15.5 & 70.7 & 181 & 7.3 & 462 \\
\hline Quail Creek Reservoir & $8 / 9 / 2010$ & 74.6 & 32.7 & 48.7 & 3.8 & 50.1 & 228 & 157 & 9.2 & 858 \\
\hline \multicolumn{11}{|c|}{ Current (2014) irrigation water with dissolved solids from Dixie Hot Springs } \\
\hline VR-6 ${ }^{2}$ (river) & $6 / 29 / 2009$ & 143 & 48.1 & 308 & 25 & 479 & 436 & 202 & 14.5 & 2,590 \\
\hline VR-6 (river) & $6 / 10 / 2010$ & 140 & 39.3 & 262 & 21 & 377 & 338 & 144 & 14.9 & 2,120 \\
\hline VR-6 (river) & $8 / 11 / 2010$ & 152 & 41.1 & 256 & 21 & 394 & 375 & 281 & 12.9 & 2,320 \\
\hline LAT-1 (canal) & $5 / 24 / 2010$ & 96.1 & 22.8 & 72.8 & 7.1 & 102 & 168 & 191 & 9.9 & 944 \\
\hline \multicolumn{11}{|c|}{ Water from sources downgradient of agricultural areas } \\
\hline WFW (well) & $8 / 21 / 2000$ & 449 & 135 & 404 & 20 & 616 & 1,560 & 403 & 25.9 & 4,660 \\
\hline DRN-1 (drain) & $5 / 24 / 2010$ & 491 & 134 & 543 & 24 & 819 & 1,430 & 373 & 20.8 & 5,120 \\
\hline DRN-1 (drain) & $8 / 9 / 2010$ & 301 & 83.2 & 407 & 27 & 648 & 948 & 312 & 18.7 & 3,860 \\
\hline DRN-2 (drain) & $5 / 24 / 2010$ & 327 & 91.9 & 339 & 19 & 501 & 966 & 331 & 17.6 & 3,620 \\
\hline DRN-2² (drain) & $8 / 9 / 2010$ & 398 & 116 & 463 & 27 & 729 & 1,280 & 399 & 21.3 & 4,600 \\
\hline DRN-2a (drain) & $5 / 25 / 2010$ & 465 & 135 & 515 & 28 & 748 & 1,310 & 426 & 22.1 & 4,740 \\
\hline
\end{tabular}

${ }^{1}$ Site names and associated site descriptions are listed in table 1.

${ }^{2}$ Chemical analysis used in mass-balance calculations.

SNORM in the mass-transfer application of the geochemical modeling program PHREEQC (Parkhurst and Appelo, 1999).

If the drain samples are assumed to include the dissolution of all available minerals precipitated in the soil during the previous irrigation season, then a change to more dilute irrigation water will not dissolve additional minerals and increase the dissolved-solids load in the drain discharge. The groundwater sample from well WFW (265-ft deep, table 9) had a very similar chemistry and specific conductance to water sampled from the drains, indicating that longer vertical flow paths do not dissolve substantially more salt from deeper soil profiles or underlying geology. This suggests that the current irrigation water does dissolve all salts available in the soil during an annual cycle. The greater net gain of dissolved constituents determined from the mass-balance calculations using the application of potential irrigation water without dissolved solids from Dixie Hot Springs (tables 10 and 11) is the result of using the same sample to represent the end water from the agricultural drain (table 9) in the calculations for both the current and potential irrigation water scenarios. The larger net gain determined for the potential irrigation water should only be the case for the first year and is based on the conceptual model that all available salts left in the agricultural fields are dissolved by water applied to the fields the following irrigation season. After one (or several) seasons of irrigating with potential irrigation water without dissolved solids from Dixie Hot Springs, mineral precipitation and subsequent re-dissolution beneath the agricultural fields should be greatly reduced, leading to a reduction in dissolved-solids load to the Virgin River downstream of the agricultural drains.

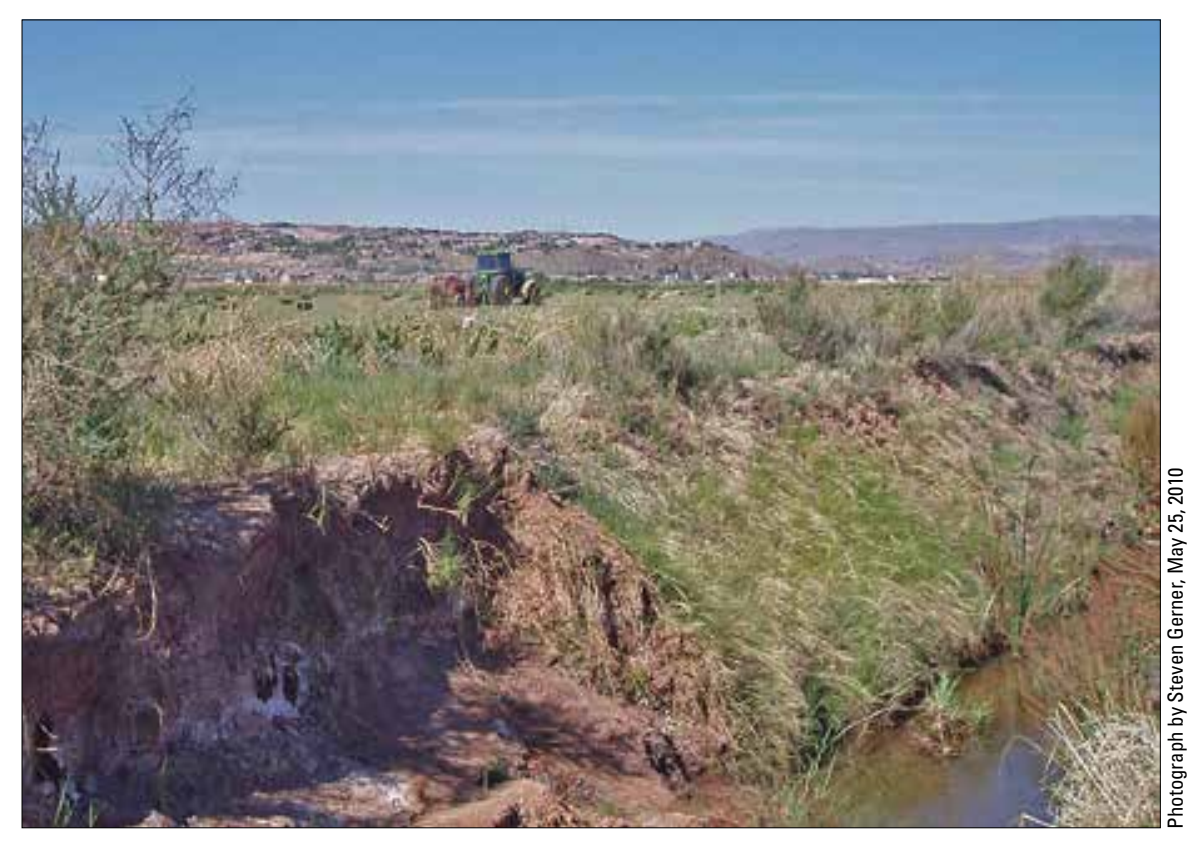

Drainage ditch and efflorescent salt in agricultural area, looking northwest, near St. George, Utah, May 2010. 


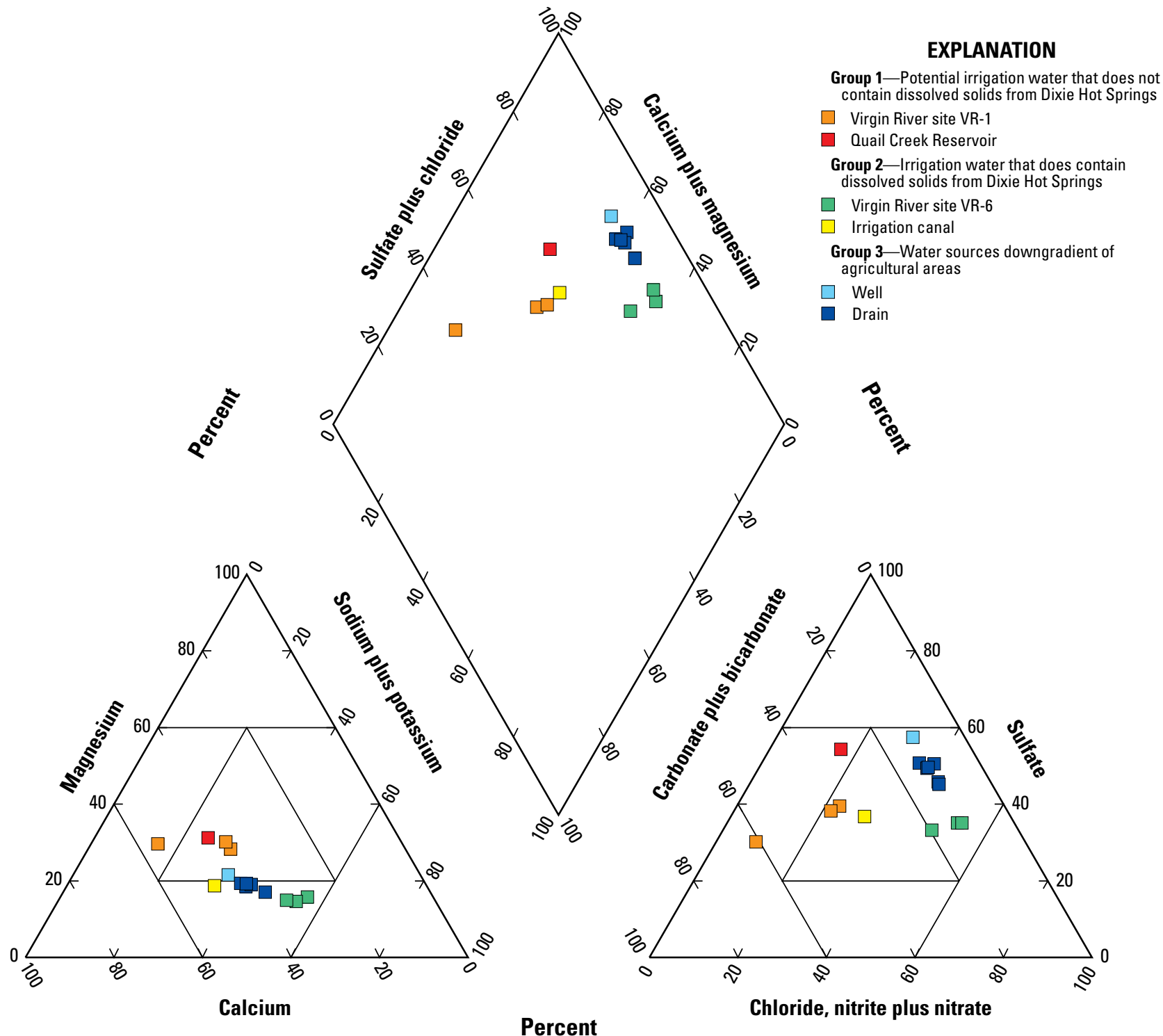

Figure 12. Composition of selected water samples representing irrigation inflow to agricultural areas near St. George and Washington, Utah, and discharge from sources downgradient of the agricultural areas.

Table 10. Net change in dissolved constituent concentrations between water applied to irrigated fields and water sampled from an agricultural drain near St. George and Washington, Utah.

\begin{tabular}{|c|c|c|c|c|c|}
\hline Dissolved constituent & $\begin{array}{l}\text { Potential irrigation water } \\
\text { without dissolved solids } \\
\text { from Dixie Hot Springs }\end{array}$ & $\begin{array}{l}\text { Current (2014) irrigation } \\
\text { water with dissolved solids } \\
\text { from Dixie Hot Springs }\end{array}$ & $\begin{array}{l}\text { Water sampled from } \\
\text { agricultural drain DRN-2 }\end{array}$ & $\begin{array}{c}\text { Net change between } \\
\text { potential irrigation water } \\
\text { and water from } \\
\text { agricultural drain }\end{array}$ & $\begin{array}{l}\text { Net change between cur- } \\
\text { rent (2014) irrigation water } \\
\text { and water from } \\
\text { agricultural drain }\end{array}$ \\
\hline Calcium & 57.9 & 143 & 398 & 340 & 255 \\
\hline Magnesium & 26.8 & 48.1 & 116 & 89 & 68 \\
\hline Sodium & 48.5 & 308 & 463 & 414 & 155 \\
\hline Potassium & 3.5 & 25 & 27 & 23 & 1.8 \\
\hline Chloride & 57.7 & 479 & 729 & 671 & 250 \\
\hline Sulfate & 136 & 436 & 1,280 & 1,140 & 844 \\
\hline Bicarbonate & 180 & 202 & 399 & 219 & 197 \\
\hline Sum of dissolved solids & 429 & 1,550 & 3,230 & 2,801 & 1,680 \\
\hline
\end{tabular}


Table 11. Potential minerals dissolved from soils in agricultural areas near St. George and Washington, Utah, and the change in mineral concentration between water diverted to agricultural areas and water discharging from those areas.

[All concentrations in millimoles per liter; $\mathrm{Na}$, sodium; $\mathrm{Cl}$, chloride; $\mathrm{Ca}$, calcium; $\mathrm{SO}_{4}$, sulfate; $\mathrm{CO}_{2}$, carbon dioxide; $\mathrm{Mg}$, magnesium; $\mathrm{CO}$, carbonate; $\mathrm{K}$, potassium; <, less than]

\begin{tabular}{|c|c|c|c|c|}
\hline Mineral & Chemical composition & $\begin{array}{c}\text { Net change in concentration } \\
\text { between current (2014) irrigation } \\
\text { water with dissolved solids from } \\
\text { Dixie Hot Springs and water from } \\
\text { agricultural drain }\end{array}$ & $\begin{array}{c}\text { Net change in concentration } \\
\text { between potential irrigation water } \\
\text { without dissolved solids from } \\
\text { Dixie Hot Springs and water from } \\
\text { agricultural drain }\end{array}$ & $\begin{array}{l}\text { Possible increase in concentration } \\
\text { in water from agricultural drain } \\
\text { after first irrigation season using } \\
\text { potential irrigation water without } \\
\text { dissolved solids from Dixie Hot } \\
\text { Springs }\end{array}$ \\
\hline Halite & $\mathrm{NaCl}$ & 6.3 & 17.6 & 11.3 \\
\hline Anhydrite & $\mathrm{CaSO}_{4}$ & 6.5 & 8.2 & 1.7 \\
\hline Carbon dioxide (gas) ${ }^{1}$ & $\mathrm{CO}_{2}$ & 2.1 & 2.4 & 0.3 \\
\hline Magnesite & $\mathrm{MgCO}_{3}$ & 1.9 & 2.2 & 0.3 \\
\hline Polyhalite & $\mathrm{Ca}_{2} \mathrm{~K}_{2} \mathrm{Mg}\left(\mathrm{SO}_{4}\right)_{4}$ & $<0.1$ & 0.3 & 0.3 \\
\hline Bloedite & $\mathrm{Na}_{2} \mathrm{Mg}\left(\mathrm{SO}_{4}\right)_{2}$ & 1.0 & 1.1 & 0.1 \\
\hline
\end{tabular}

${ }^{1}$ Atmospheric gas transfer accounts for change in total carbon.

\section{Summary}

Water from the Virgin River, with elevated dissolved-solids concentrations, is diverted for irrigation in agricultural areas near St. George and Washington, Utah. Evapotranspiration and mineral dissolution in the agricultural fields increase the dissolved-solids concentrations in the irrigation water that is not taken up by plants or evaporated. Some of this water is returned to the river as excess irrigation water through agricultural drains and some also infiltrates past the root zone and the level intercepted by drainage ditches to become groundwater recharge. This groundwater can dissolve additional minerals as it moves through the sediment and underlying geologic formations. If dissolved solids entering the Virgin River from Dixie Hot Springs were reduced, the potential irrigation water applied in these agricultural areas would be more dilute than it is at present. As a result, the processes that increase dissolvedsolids concentrations in the irrigation water in the agricultural fields may be altered.

Analysis of water samples from irrigation inflow and agricultural drains were used in mass-balance calculations. These calculations indicate a potential for more dissolution and dissolved-solids loading to the agricultural drains if more efflorescent salts are available. Thus, if more dilute irrigation water were applied in these agricultural areas, the dissolution of minerals left in the soil from the previous irrigation season by this potential irrigation water would result in a net increase in dissolved solids, but this increase should only last one irrigation season. After that time, the quantity of minerals in the agricultural fields that is available for dissolution would decrease because the potential irrigation water would leave fewer minerals in the soil.

\section{References Cited}

Bodine, M.W., and Jones, B.F., 1986, The SALT NORM: A quantitative chemical-mineralogical characterization of natural waters: U.S. Geological Survey Water-Resources Investigations Report 86-4086, $130 \mathrm{p}$.

Parkhurst, D.L., and Appelo, C.A.J., 1999, User's guide to PHREEQC (Version 2) - A computer program for speciation, batch-reaction, one-dimensional transport, and inverse geochemical calculations: U.S. Geological Survey WaterResources Investigations Report 99-4259, 312 p. 


\title{
Chapter 7. Hypothetical Dissolved-Solids Loads in the Virgin River Following the Reduction of Dissolved Solids in Discharge from Dixie Hot Springs
}

\author{
By Steven J. Gerner
}

Because of the economic damages that result from high dissolved-solids concentrations in the Colorado River, there has been interest since the 1970s in predicting how dissolvedsolids loads in its tributary, the Virgin River, would change if the dissolved solids discharged from Dixie Hot Springs were reduced or removed. Current modeling tools and up-to-date hydrologic and geochemical data were used in the present study to estimate discharge and dissolved-solids loads from Dixie Hot Springs (chapter 2), dissolved-solids loads for selected sites on the Virgin River and some of its tributaries (chapter 3), seepage losses from the Virgin River above the Narrows to the groundwater system (chapter 4), and groundwater residence time of discharge to Littlefield Springs (chapter 5). This chapter discusses how information presented in chapters 2-5 was used in a mass-balance model, similar to that previously used by Reclamation (Bureau of Reclamation, 1984a) to determine dissolved-solids loads in the Virgin River before and after the hypothetical reduction or removal of dissolved solids from Dixie Hot Springs discharge. Reduction of dissolved solids in the river is assumed to occur as a result of an undefined salt mitigation project that collects Dixie Hot Springs outflow, removes nearly all of the dissolved solids, and then discharges most of the water to the Virgin River. The Reclamation studies of the 1980s proposed several scenarios to accomplish this, including the use of a reverse osmosis facility.

\section{Estimates, Calculations, and Assumptions Used in the Mass-Balance Model}

Estimates of discharge, dissolved-solids concentrations, and dissolved-solids loads in the Virgin River and inflow to and outflow from the river between the towns of Virgin, Utah, and Littlefield, Arizona, were examined in a mass-balance model. The mass-balance model follows the conceptual model shown in figure 13. The model was used to predict changes in dissolved-solids loads in the Virgin River that would result if dissolved solids discharged from Dixie Hot Springs were reduced or removed under two different scenarios. The primary variable in these scenarios is the seepage loss to the groundwater system from the Virgin River in and just upstream of the Virgin River Gorge. The volumes of water lost through seepage were determined from paired monthly average streamflow at the bounding gaging stations at sites VR-7, VR-8, and VR-14 (see chapter 4). The first scenario (table 12) uses an average annual discharge and dissolved-solids load determined for site
VR-7 to represent discharge and loads upstream of the seepage loss and assumes that seepage loss from the river between sites VR-7 and VR-14 is $33.4 \mathrm{ft}^{3} / \mathrm{s}$. This scenario includes seepage loss between sites VR-7 and VR-8. The second scenario (table 13) uses an average annual discharge and dissolved-solids load determined for site VR-8 to represent discharge and loads upstream of the seepage loss and assumes that seepage loss from the river between sites VR-8 and VR-14 is $26.7 \mathrm{ft}^{3} / \mathrm{s}$. This scenario assumes that the seepage loss in the reach from sites VR-7 to VR-8 $\left(6.7 \mathrm{ft}^{3} / \mathrm{s}\right)$ is not significant when compared to the uncertainty in the estimation method, as explained in chapter 4 . For the mass-balance model, average estimated annual discharge and dissolved-solids loads from selected sites and river reaches in the Virgin River Basin for WYs 19992001, 2003-04, and 2006-10 (1999-2010, excluding 2002 and 2005) were used.

The following estimates, calculations, and assumptions were incorporated into one or both scenarios of the massbalance model:

- Both scenarios: Average annual dissolved-solids loads at sites VR-7, SGWRF, VR-8, VR-14, and VR-15 were determined from discharge data from WYs 1999-2001, 2003-2004, and 2006-2010 (table 7). Annual flows (and associated dissolved-solids loads) from 2002 and 2005 were not included in this analysis because annual flows during these years are outliers that were either less than the 10th percentile (2002) or greater than the 90th percentile (2005) of annual flows.

- Both scenarios: Discharge in the Virgin River above Dixie Hot Springs and below the Quail Creek diversion dam was estimated to be $50 \mathrm{ft}^{3} / \mathrm{s}$ (fig. 13) from the Virgin River Daily Simulation Model (VRDSM) (Nathan Kennard, Utah Division of Water Rights, written commun., July 2012). The VRDSM, developed by the Utah Division of Water Resources, is calibrated with stream-gaging station data to simulate monthly streamflow in the river system from the Virgin River at Virgin, Utah (site VR-1, above the Quail Creek diversion dam), to site VR-8. In the following discussion, the Virgin River above Dixie Hot Springs and below the Quail Creek diversion dam is described as the Virgin River above Dixie Hot Springs. Dissolved-solids concentration in the Virgin River above Dixie Hot Springs (tables 12 and 13) was assumed to be the same as at site VR-1 (430 mg/L). This concentration was calculated using the average annual dissolved-solids load (56,400 ton/yr in table 7) and average annual discharge (133 $\mathrm{ft}^{3} / \mathrm{s}$ in table 7$)$ at site VR-1. 


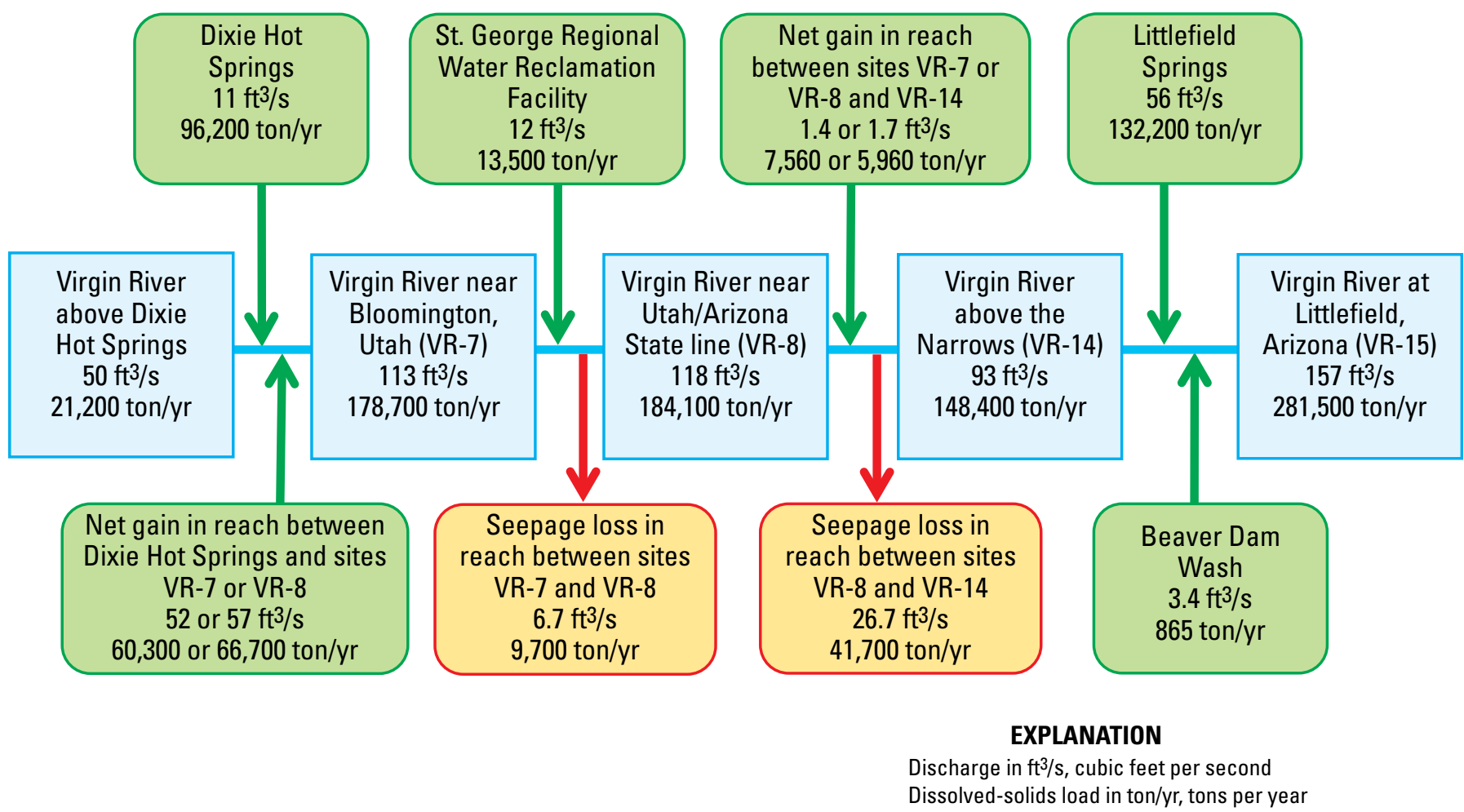

Figure 13. Conceptual model illustrating the average annual discharge and dissolved-solids load at selected sites on the Virgin River for water years 1999-2001, 2003-04, and 2006-10, and intermediate gains or losses of discharge and dissolved-solids load.

- Both scenarios: The discharge and dissolved-solids load from Dixie Hot Springs (fig. 13) were assumed to be the average of measurements made during $2009-10\left(11 \mathrm{ft}^{3} / \mathrm{s}\right.$ and 96,200 ton/yr, table 4). The dissolved-solids concentration in water from Dixie Hot Springs listed in tables 12 and $13(8,880 \mathrm{mg} / \mathrm{L})$ is calculated from these values of averaged discharge and load.

- Both scenarios: Hypothetical treated discharge and dissolved-solids load from Dixie Hot Springs were estimated based on the following assumptions. After treatment, 73 percent of Dixie Hot Springs water $\left(8 \mathrm{ft}^{3} / \mathrm{s}\right)$ would be discharged to the Virgin River with a dissolvedsolids concentration of $284 \mathrm{mg} / \mathrm{L}$ (Bureau of Reclamation, 1984a). The difference in discharge $\left(3 \mathrm{ft}^{3} / \mathrm{s}\right)$ would be replaced with water from Quail Creek Reservoir, which had a dissolved-solids concentration of $525 \mathrm{mg} / \mathrm{L}$ in 2010 (table 1). The post-treatment dissolved-solids load to the Virgin River is the flow-weighted combination of these two sources (3,790 ton/yr in tables 12 and 13).

- First scenario: The net gain in discharge and dissolved solids to the Virgin River in the reach from Dixie Hot Springs to site VR-7 (near Bloomington, Utah; fig. 13) used in the first scenario (table 12) was determined by subtracting the discharge and dissolved-solids load for the Virgin River above Dixie Hot Springs and for Dixie Hot Springs from the discharge and dissolved-solids load in the river at site VR-7. This reach of the river includes inflow of water and dissolved solids from tributaries (including Fort Pearce Wash and the Santa Clara River), Quail Creek Reservoir return flow, and excess irrigation water draining agricultural areas near St. George and Washington, Utah.

- Second scenario: The net gain in discharge and dissolved solids to the Virgin River in the reach from Dixie Hot Springs to site VR-8 (fig. 13) used in scenario 2 (table 13) was determined by subtracting the discharge and dissolved-solids load for the Virgin River above Dixie Hot Springs and for Dixie Hot Springs from the discharge and dissolved-solids load in the river at site VR-8. This reach of the river is similar to that from Dixie Hot Springs to VR-7, but includes outflow from the SGWRF. Note that seepage losses from the Virgin River between sites VR-7 and VR-8 (fig. 13) are not included in this estimate.

- First scenario: The average annual dissolved-solids load for the study period at site VR-7 (fig. 13) was determined using modeled values listed in table 7 (178,700 ton/yr). The hypothetical post-treatment discharge at site VR-7 is assumed to be the same as before treatment. The hypothetical post-treatment dissolved-solids load at site VR-7 (table 12) is calculated as the sum of loads for (1) the Virgin River above Dixie Hot Springs, (2) treated water from and replacement water for Dixie Hot Springs, and 
Table 12. Average annual discharge, dissolved-solids concentration, and dissolved-solids load at selected sites and reaches in the Virgin River and its tributaries for the period that includes water years 1999-2001, 2003-04, and 2006-10, estimated for a scenario that assumes a total seepage loss of 33.4 cubic feet per second from the Virgin River in and near the Virgin River Gorge.

[Seepage from the Virgin River in and near the Virgin River Gorge is assumed to be 33.4 cubic feet per second (scenario 1, includes estimated seepage loss between sites VR-7 and VR-8)]

\begin{tabular}{|c|c|c|c|}
\hline Site description & $\begin{array}{l}\text { Discharge, in cubic feet per } \\
\text { second }\end{array}$ & $\begin{array}{l}\text { Dissolved-solids concentra- } \\
\text { tion, in milligrams per liter }\end{array}$ & $\begin{array}{l}\text { Dissolved-solids load, in } \\
\text { tons per year }\end{array}$ \\
\hline \multicolumn{4}{|c|}{ Prior to treatment of Dixie Hot Springs discharge ${ }^{1}$} \\
\hline Virgin River above Dixie Hot Springs ${ }^{2}$ & 50 & 430 & 21,200 \\
\hline Dixie Hot Springs & 11 & 8,880 & 96,200 \\
\hline Net gain in reach between Dixie Hot Springs and site VR-7 & 52 & 1,200 & 60,300 \\
\hline Virgin River near Bloomington, Utah (site VR-7) & 113 & 1,600 & 178,700 \\
\hline St. George Regional Water Reclamation Facility (SGWRF) & 12 & 1,140 & 13,500 \\
\hline Seepage loss from Virgin River between sites VR-7 and VR-14 & 33.4 & 1,560 & 51,400 \\
\hline Net gain in reach between sites VR-7 and VR-14 & 1.4 & 5,480 & 7,560 \\
\hline Virgin River above Narrows (site VR-14) & 93 & 1,620 & 148,400 \\
\hline Littlefield Springs & 56 & 2,400 & 132,200 \\
\hline Beaver Dam Wash & 3.4 & 258 & 865 \\
\hline Virgin River at Littlefield, Arizona (site VR-15) & 157 & 1,820 & 281,500 \\
\hline \multicolumn{4}{|c|}{ After treatment of Dixie Hot Springs discharge ${ }^{1}$} \\
\hline Virgin River above Dixie Hot Springs ${ }^{2}$ & 50 & 430 & 21,200 \\
\hline Dixie Hot Springs & 11 & 350 & 3,790 \\
\hline Net gain in reach between Dixie Hot Springs and site VR-7 & 52 & 1,200 & 61,300 \\
\hline Virgin River near Bloomington, Utah (site VR-7) & 113 & 775 & 86,300 \\
\hline St. George Regional Water Reclamation Facility (SGWRF) & 12 & 1,140 & 13,500 \\
\hline Seepage loss from Virgin River between sites VR-7 and VR-14 & 33.4 & 810 & 26,700 \\
\hline Net gain in reach between sites VR-7 and VR-14 & 1.4 & 5,480 & 7,560 \\
\hline Virgin River above Narrows (site VR-14) & 93 & 880 & 80,700 \\
\hline Littlefield Springs & 56 & 2,400 & 132,200 \\
\hline Beaver Dam Wash & 3.4 & 258 & 865 \\
\hline Virgin River at Littlefield, Arizona (site VR-15) & 157 & 1,380 & 213,800 \\
\hline \multicolumn{4}{|c|}{ Dissolved-solids load reduction in the Virgin River at Littlefield, Arizona, after treatment of Dixie Hot Springs discharge ${ }^{1}$} \\
\hline Initial dissolved-solids load savings & & & 67,700 \\
\hline $\begin{array}{l}\text { Possible additional dissolved-solids load savings after seepage with reduced } \\
\text { dissolved-solids load discharges from Littlefield Springs. }\end{array}$ & & & 24,700 \\
\hline Total & & & 92,400 \\
\hline
\end{tabular}

${ }^{1}$ Refers to treatment of Dixie Hot Springs to reduce discharge of dissolved solids into the Virgin River.

${ }^{2}$ Virgin River above Dixie Hot Springs and below the Quail Creek diversion dam.

(3) inflow to the river in the intervening reach between Dixie Hot Springs and VR-7 (this component is assumed to be the same as before treatment).

- First scenario: The average annual dissolved-solids load in outflow from the SGWRF (fig. 13) for the study period was 13,500 ton/yr (table 7). The hypothetical post-treatment dissolved-solids load for the SGWRF is assumed to be the same as before treatment (table 12).

- Second scenario: The average annual dissolved-solids load for the study period at site VR-8 (fig. 13) was determined from modeled values listed in table 7 $(184,100$ ton/yr). The hypothetical post-treatment dis- charge at site VR-8 is assumed to be the same as before treatment. The hypothetical post-treatment dissolvedsolids load at site VR-8 (table 13) is calculated as the sum of loads for (1) the Virgin River above Dixie Hot Springs, (2) treated and replacement water from Dixie Hot Springs, and (3) inflow to the river in the intervening reach between Dixie Hot Springs and VR-8 (this component is assumed to be the same as before treatment).

- Both scenarios: Estimated seepage losses from the Virgin River between sites VR-7 and VR-14 $\left(33.4 \mathrm{ft}^{3} / \mathrm{s}\right.$, first scenario) and between VR-8 and VR-14 $\left(26.7 \mathrm{ft}^{3} / \mathrm{s}\right.$, second scenario), are described in chapter 4 and shown on figure 13 . 
Table 13. Average annual discharge, dissolved-solids concentration, and dissolved-solids load at selected sites and reaches in the Virgin River and its tributaries for the period that includes water years 1999-2001, 2003-04, and 2006-10, estimated for a scenario that assumes a total seepage loss of 26.7 cubic feet per second from the Virgin River in and near the Virgin River Gorge.

[Seepage from the Virgin River in and near the Virgin River Gorge is assumed to be 26.7 cubic feet per second (scenario 2, does not include estimated seepage loss between sites VR-7 and VR-8)]

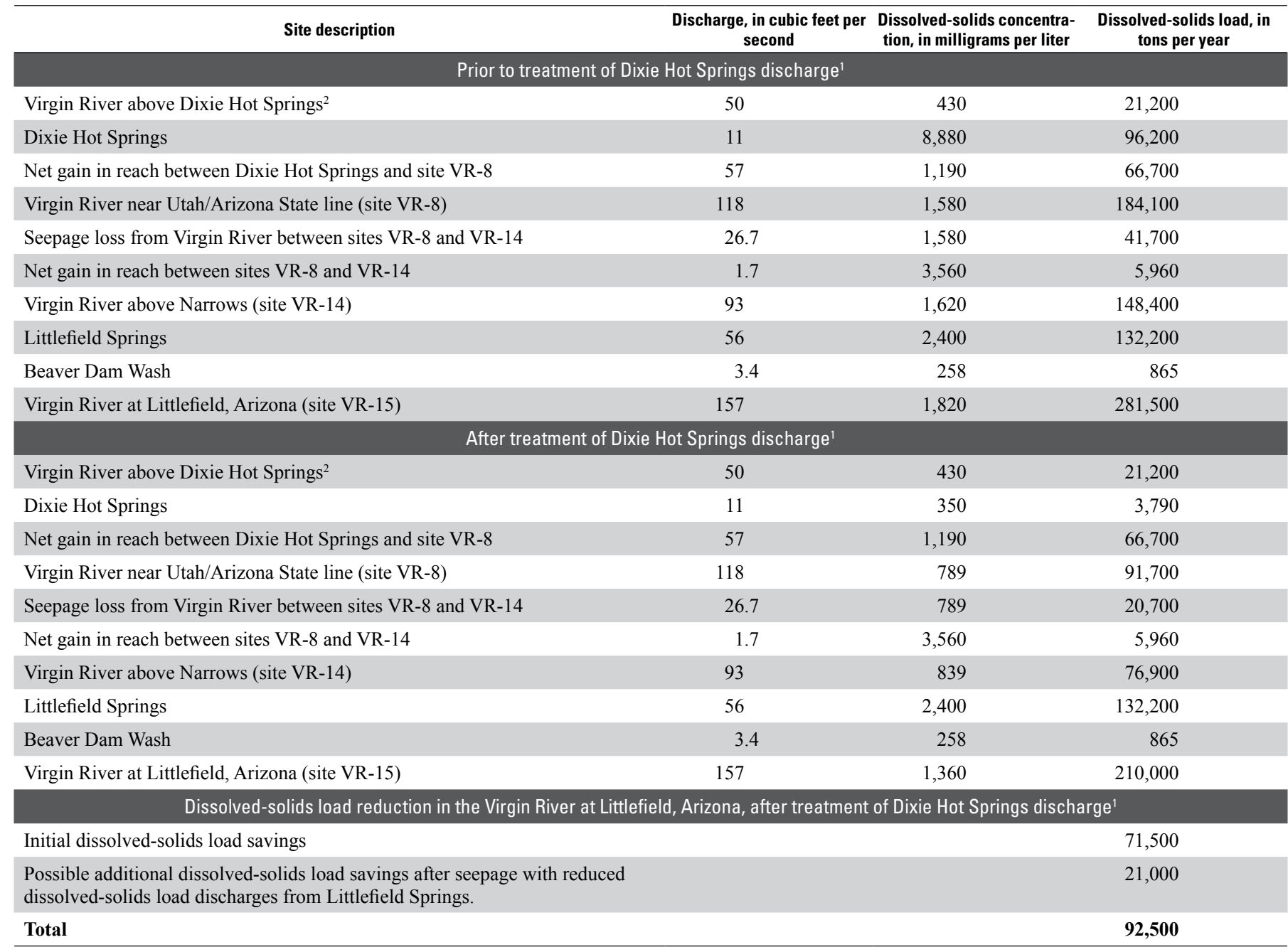

${ }^{1}$ Refers to treatment of Dixie Hot Springs to reduce discharge of dissolved solids into the Virgin River.

${ }^{2}$ Virgin River above Dixie Hot Springs and below the Quail Creek diversion dam.

- Both scenarios: The net gain in discharge and dissolvedsolids load between sites VR-7 and VR-14 (table 12) and sites VR-8 and VR-14 (table 13) was determined by subtracting the discharge and dissolved-solids load for (1) the Virgin River at the upstream site (site VR-7 or VR-8) plus (2) outflow from the SGWRF (in the case of reach VR-7 to VR-14) from the discharge and dissolved-solids load at site VR-14, and then adding (3) the seepage loss between sites VR-7 and VR-14 or VR-8 and VR-14. The hypothetical post-treatment dissolved-solids load for this computed small net gain in discharge between sites VR-7 and VR-14 and sites VR-8 and VR-14 is assumed to be the same as the load prior to treatment because the posttreatment load at site VR-14 is calculated from upstream sources (see next bullet).
- Both scenarios: The average annual dissolved-solids load for the study period at site VR-14 (fig. 13), which represents pre-treatment loads at the site, was determined using modeled values listed in table 7 (148,400 ton/yr). The hypothetical post-treatment discharge at site VR-14 is assumed to be the same as before treatment. The hypothetical post-treatment dissolved-solids load at site VR-14 (tables 12 and 13) is calculated as the sum of loads for (1) the Virgin River at the upstream site (site VR-7 or VR-8), (2) outflow from the SGWRF (in the case of the first scenario), and (3) the net gain between sites VR-7 and VR-14 (first scenario) or net gain between sites VR-8 and VR-14 (second scenario), minus (4) the load in seepage loss between sites VR-7 or VR-8 and VR-14. 
- Both scenarios: The average annual discharge from Littlefield Springs of $56 \mathrm{ft}^{3} / \mathrm{s}$ (fig. 13), reported by the author to Reclamation and the Colorado River Basin Salinity Control Forum (Steven Gerner, U.S. Geological Survey, written commun., 2008), is assumed to be representative of the study period. The annual dissolved-solids load for Littlefield Springs (tables 12 and 13) was calculated by subtracting the average annual dissolved-solids load at site VR-14 and Beaver Dam Wash from that at site VR-15. The dissolved-solids concentration of water from Littlefield Springs is calculated from the discharge and load estimates. The resulting concentration of $2,400 \mathrm{mg} / \mathrm{L}$ is about 16 percent less than the average dissolved-solids concentration determined from the sum of constituents $(2,780 \mathrm{mg} / \mathrm{L})$ for seven samples collected from Littlefield Springs during 2009-10 (table 1).

- Both scenarios: The average annual dissolved-solids load for the study period at site VR-15 (Virgin River at Littlefield, Arizona; fig. 13) was determined from modeled values listed in table $7(281,500 \mathrm{ton} / \mathrm{yr})$. The hypothetical post-treatment discharge at site VR-15 is assumed to be the same as before treatment. The hypothetical posttreatment dissolved-solids load at site VR-15 (tables 12 and 13) was calculated as the sum of loads for the Virgin River at site VR-14, Littlefield Springs, and Beaver Dam Wash.

\section{Dissolved-Solids Loads Estimated by the Mass-Balance Model}

The mass-balance model was used to predict the changes in dissolved-solids load in the Virgin River that would result if the dissolved solids discharged from Dixie Hot Springs were reduced or removed. Two scenarios of seepage loss from the river in and just upstream of the Virgin River Gorge (described in the previous section) were used in the model. In the first scenario (table 12), seepage loss from the Virgin River is expected to occur in the reach from sites VR-7 to VR-14 $\left(33.4 \mathrm{ft}^{3} / \mathrm{s}\right)$. In the second scenario (table 13), seepage loss from the river is expected to occur only in the reach from sites VR-8 to VR-14 (26.7 ft $\left.\mathrm{ft}^{3} / \mathrm{s}\right)$.

The dissolved-solids concentration of seepage from the river between VR-7 and VR-14 (first scenario) is estimated to be the flow-weighted concentration in the combined discharge at site VR-7 and from SGWRF $(1,560 \mathrm{mg} / \mathrm{L})$. Using the load equation described in chapter 2 (equation 2 ), the dissolvedsolids load in the total seepage loss of $33.4 \mathrm{ft}^{3} / \mathrm{s}$ is calculated to be 51,400 ton/yr. The dissolved-solids concentration of water lost to seepage in the reach between VR-8 and VR-14 (second scenario) is estimated to be the same as the value determined from discharge and modeled dissolved-solids load at site VR-8 $(1,580 \mathrm{mg} / \mathrm{L})$. Using the load equation, the dissolved-solids load in the seepage loss from the Virgin River between sites VR-8 and VR-14 is calculated to be 41,700 ton/yr.
If the dissolved solids from Dixie Hot Springs were prevented from discharging into the Virgin River, the flowweighted dissolved-solids concentrations and loads in the river downstream would decrease substantially. The immediate reduction in dissolved-solids load in the Virgin River at Littlefield (site VR-15) under the first scenario, with $33.4 \mathrm{ft}^{3} / \mathrm{s}$ of seepage loss, is predicted in the mass-balance model to be $67,700 \mathrm{ton} / \mathrm{yr}$, a decrease of about 24 percent (table 12). The flow-weighted dissolved-solids concentration in seepage from the Virgin River downstream of site VR-7 is predicted to be reduced from $1,560 \mathrm{mg} / \mathrm{L}$ to $810 \mathrm{mg} / \mathrm{L}$, a reduction of about half. As a result, the amount of dissolved solids moving from the Virgin River into the groundwater system that discharges at Littlefield Springs is predicted to be reduced from 51,400 to 26,700 ton/yr. This reduction in dissolved-solids load in seepage to the groundwater system is expected to reduce the load discharged from Littlefield Springs after approximately 26 years (the estimated time lag between seepage from the river and discharge from Littlefield Springs, representing subsurface traveltime, as discussed in chapter 5). At that time, the entire reduction in dissolved solids in seepage loss from the Virgin River is expected to be realized as a reduction in dissolved solids discharging from Littlefield Springs, resulting in an additional reduction of 24,700 ton/yr in the dissolved-solids load at site VR-15. The mass-balance model under this first scenario estimates a total dissolved-solids load reduction in the Virgin River at site VR-15 of 92,400 ton/yr, or a decrease of 33 percent.

In the second scenario, if the dissolved solids from Dixie Hot Springs were prevented from discharging into the Virgin River, the flow-weighted dissolved-solids concentration in seepage from the river downstream of site VR-8 is predicted in the model to be reduced to $789 \mathrm{mg} / \mathrm{L}$, slightly less than the concentration predicted in the first scenario. The immediate reduction in dissolved-solids load in the Virgin River at Littlefield (site VR-15) under this scenario, with $26.7 \mathrm{ft}^{3} / \mathrm{s}$ of seepage loss, is predicted in the mass-balance model to be $71,500 \mathrm{ton} / \mathrm{yr}$, or a decrease of about 25 percent (table 13). The amount of dissolved solids moving from the Virgin River into the groundwater system that discharges at Littlefield Springs is predicted to be reduced from 41,700 to 20,700 ton/yr. As in the first scenario, the reduced inflow of dissolved solids to the Littlefield Springs system is expected to affect the dissolvedsolids load discharging from Littlefield Springs after approximately 26 years. At that time, the entire reduction in dissolved solids in seepage loss from the Virgin River is expected to be realized as a reduction in dissolved solids discharging from Littlefield Springs, resulting in an additional reduction of 21,000 ton/yr in the dissolved-solids load at site VR-15. The total reduction in dissolved-solids load estimated by the mass-balance model for this scenario with $26.7 \mathrm{ft}^{3} / \mathrm{s}$ of seepage loss from the river $(92,500$ ton/yr, table 13$)$ is the same as the scenario with more seepage, because all of the loss is assumed to be reflected in the reduced load in discharge from Littlefield Springs. 
These scenarios apply a simplified approach to predicting the outcome of reducing the dissolved-solids load from Dixie Hot Springs to the Virgin River. The discharge and dissolvedsolids load in the Virgin River is highly variable over short and long time periods, resulting in highly variable average loads depending on the time period represented. Thus, these predictions represent the average discharge and dissolved-solids load in the Virgin River for the time period used in the model (WYs 1999-2001, 2003-04, and 2006-10), and results would likely be different if another time period were chosen. The reader should review the assumptions underlying the model and each scenario when interpreting the results and consider the following:

- Due to the hypothetical removal of the dissolved-solids load from Dixie Hot Springs to the Virgin River, less dissolved solids would be in water diverted into the St. George and Washington Canal and applied to agricultural land. Dissolved-solids loads to the river from excess irrigation water between Dixie Hot Springs and sites VR-7 and VR-8 are likely to be reduced over time following the treatment of Dixie Hot Springs water as dissolved solids are flushed from the irrigated fields. This would result in a further reduction in the dissolved-solids load at site VR-15 that is not currently modeled.

- The dissolved-solids load discharging from the SGWRF likely will increase over time if population grows in the St. George area. This would result in an increase in the annual dissolved-solids load at site VR-15.

- The models use flow-weighted dissolved-solids concentrations and assume a steady amount of inflow to and seepage from the Virgin River in the study area. Seepage of more dilute water from the river to the groundwater system occurs for a short time during periods of snowmelt in the drainage basin - the months of February and March had the largest monthly average streamflow at sites VR-7 and VR-8 during 1992-2010. Seepage of water with higher dissolved-solids concentrations from the river occurs for a much longer time each year. Thus, if seepage losses are constant throughout the year, the amount of salt lost in seepage has been underpredicted in the models.

- Analysis of geochemical and environmental tracer data collected from Littlefield Springs and presented in chapter 5 indicates that about 60 percent $\left(34 \mathrm{ft}^{3} / \mathrm{s}\right)$ of the discharge from the springs originates as seepage from the Virgin River. This suggests that the first scenario (with the larger estimated amount of seepage) is most likely to represent actual conditions when predicting the effects of removing the dissolved solids in discharge from Dixie Hot Springs on dissolved-solids loads in the Virgin River at Littlefield, Arizona.

\section{Summary}

Because of the economic damages that result from high dissolved-solids concentrations in the Colorado River, there has been interest since the 1970s in predicting how dissolvedsolids loads in its tributary, the Virgin River, would change if the salt discharged from Dixie Hot Springs were reduced or removed. Information presented in chapters $2-5$ was used in a simple mass-balance model to determine dissolved-solids loads in the Virgin River before and after hypothetical reduction of dissolved solids from Dixie Hot Springs to the river resulting from the implementation of salinity control. The information from previous chapters includes:

- annual discharge and dissolved-solids load from Dixie Hot Springs;

- annual dissolved-solids load at selected sites in the Virgin River Basin;

- streamflow losses in the Virgin River in and near the Virgin River Gorge; and

- age of the Virgin River component in discharge from Littlefield Springs.

The model used two scenarios that differed in terms of the amount and location of seepage loss to the groundwater system from the Virgin River in and just upstream of the Virgin River Gorge.

In the first scenario of the mass-balance model, seepage loss of $33.4 \mathrm{ft}^{3} / \mathrm{s}$ from the river is expected to occur in the reach between site VR-7 and site VR-14. If the salt from Dixie Hot Springs were prevented from discharging into the Virgin River, the flow-weighted dissolved-solids concentration in the Virgin River downstream would decrease substantially. The immediate reduction in dissolved-solids load in the Virgin River at Littlefield (site VR-15) under this scenario is predicted in the mass-balance model to be 67,700 ton/yr, or a decrease of about 24 percent. The flow-weighted dissolvedsolids concentration in seepage from the Virgin River downstream of site VR-7 is predicted to be reduced from 1,560 to $810 \mathrm{mg} / \mathrm{L}$. As a result, the amount of salt moving from the Virgin River into the groundwater system that discharges at Littlefield Springs is predicted to be reduced from 51,400 to 26,700 ton/yr. This reduction in dissolved-solids load in seepage to the groundwater system is expected to further reduce the dissolved-solids load discharged from Littlefield Springs after approximately 26 years, resulting in an additional reduction of 24,700 ton/yr in the dissolved-solids load at site VR-15. The mass-balance model under this first scenario estimates a total dissolved-solids load reduction in the Virgin River at site VR-15 of 92,400 ton/yr, or a decrease of 33 percent. 
In the second scenario, seepage loss from the Virgin River is expected to occur only in the reach from sites VR-8 to VR-14, averaging $26.7 \mathrm{ft}^{3} / \mathrm{s}$. If the salt from Dixie Hot Springs were prevented from discharging into the Virgin River, the flow-weighted dissolved-solids concentration in seepage from the river downstream of site VR-8 is predicted in the model to be reduced to $789 \mathrm{mg} / \mathrm{L}$ - half of what it was prior to the restriction. The immediate reduction in salt load in the river at site VR-15 under this scenario is predicted in the mass-balance model to be 71,500 ton/yr, or a decrease of about 25 percent. The amount of salt moving from the Virgin River into the groundwater system that discharges at Littlefield Springs is predicted to be reduced from 41,700 to 20,700 ton/yr. The reduced salt inflow to the Littlefield Springs system is expected to affect the dissolved-solids load discharging from Littlefield Springs in approximately 26 years. At that time, the entire reduction in salt seeping from the Virgin River is expected to be realized as a reduction in salt discharging from Littlefield Springs, resulting in an additional reduction of $21,000 \mathrm{ton} / \mathrm{yr}$ in the dissolved-solids load at site VR-15 for a total annual salt load reduction of 92,500 tons.

\section{References Cited}

Bureau of Reclamation, 1984a, La Verkin Springs Unit (Utah) - Composite of reports, 1983-84 La Verkin Springs study: Bureau of Reclamation, Lower Colorado Region, variously paginated. 


\section{Hydrosalinity Studies of the Virgin River, Dixie Hot Springs, and Littlefield Springs, Utah, Arizona, and Nevada}

\section{Appendix}

Appendix 1. Annual mean streamflow and dissolved-solids load at selected sites in the Virgin River Basin, Utah, Arizona, and Nevada.

[Annual mean streamflow, the arithmetic mean for the individual daily mean discharges for the year. Annual runoff indicates the total quantity of water in runoff for a drainage area for the year and is calculated by multiplying the annual mean streamflow at the gaging station by 1.983471 to convert from cubic feet per second to acre-feet per day and by the number of days in the year. NA, not applicable]

\begin{tabular}{|c|c|c|c|c|c|c|c|c|c|}
\hline \multirow[b]{2}{*}{$\begin{array}{l}\text { Site number } \\
\text { (U.S. Geological } \\
\text { Survey down- } \\
\text { stream order } \\
\text { number) }\end{array}$} & \multirow[b]{2}{*}{ Water year } & \multirow[b]{2}{*}{$\begin{array}{l}\text { Annual mean } \\
\text { streamflow } \\
\text { (cubic feet per } \\
\text { second) }\end{array}$} & \multirow[b]{2}{*}{$\begin{array}{c}\text { Annual } \\
\text { runoff } \\
\text { (acre-feet per } \\
\text { year) }\end{array}$} & \multicolumn{6}{|c|}{ Dissolved-solids load } \\
\hline & & & & $\begin{array}{c}\text { Estimated } \\
\text { annual mean } \\
\text { load } \\
\text { (tons per day) }\end{array}$ & $\begin{array}{c}\text { Variance of } \\
\text { estimated } \\
\text { annual mean } \\
\text { load } \\
\text { (tons per day) }\end{array}$ & $\begin{array}{l}\text { Lower 95-percent } \\
\text { confidence } \\
\text { limit of } \\
\text { estimated annual } \\
\text { mean load } \\
\text { (tons per day) }\end{array}$ & $\begin{array}{l}\text { Upper 95-percent } \\
\text { confidence } \\
\text { limit of } \\
\text { estimated annual } \\
\text { mean load } \\
\text { (tons per day) }\end{array}$ & $\begin{array}{c}\text { Standard error } \\
\text { of prediction for } \\
\text { estimated annual } \\
\text { mean load } \\
\text { (tons per day) }\end{array}$ & $\begin{array}{c}\text { Estimated } \\
\text { annual load } \\
\text { (tons per year) }\end{array}$ \\
\hline 09406000 & 1992 & 137 & 99,500 & 177 & 33 & 166 & 189 & 5.8 & 64,700 \\
\hline 09406000 & 1993 & 363 & 262,800 & 289 & 232 & 260 & 320 & 15 & 105,400 \\
\hline 09406000 & 1994 & 140 & 101,400 & 178 & 15 & 170 & 186 & 4.1 & 64,900 \\
\hline 09406000 & 1995 & 300 & 217,200 & 259 & 82 & 241 & 277 & 9.2 & 94,400 \\
\hline 09406000 & 1996 & 115 & 83,500 & 149 & 7.2 & 144 & 155 & 2.8 & 54,600 \\
\hline 09406000 & 1997 & 151 & 109,300 & 172 & 11 & 165 & 179 & 3.5 & 62,800 \\
\hline 09406000 & 1998 & 262 & 189,700 & 232 & 49 & 218 & 246 & 7.1 & 84,600 \\
\hline 09406000 & 1999 & 140 & 101,400 & 169 & 16 & 161 & 177 & 4.1 & 61,500 \\
\hline 09406000 & 2000 & 125 & 90,500 & 151 & 10 & 144 & 157 & 3.3 & 55,100 \\
\hline 09406000 & 2001 & 138 & 99,600 & 159 & 13 & 152 & 166 & 3.7 & 58,000 \\
\hline 09406000 & 2002 & 85 & 61,200 & 113 & 6.2 & 108 & 118 & 2.6 & 41,200 \\
\hline 09406000 & 2003 & 107 & 77,100 & 133 & 7.7 & 127 & 139 & 2.9 & 48,500 \\
\hline 09406000 & 2004 & 107 & 77,500 & 132 & 6.8 & 127 & 138 & 2.7 & 48,400 \\
\hline 09406000 & 2005 & 524 & 379,400 & 310 & 421 & 271 & 352 & 21 & 113,100 \\
\hline 09406000 & 2006 & 166 & 120,300 & 177 & 14 & 169 & 185 & 3.8 & 64,600 \\
\hline 09406000 & 2007 & 110 & 79,500 & 135 & 4.8 & 131 & 140 & 2.3 & 49,400 \\
\hline 09406000 & 2008 & 132 & 96,000 & 153 & 6.2 & 148 & 158 & 2.7 & 55,900 \\
\hline 09406000 & 2009 & 128 & 92,700 & 152 & 6.8 & 147 & 157 & 2.8 & 55,500 \\
\hline 09406000 & 2010 & 180 & 130,100 & 185 & 17 & 176 & 193 & 4.3 & 67,400 \\
\hline 09406100 & 2006 & 107 & 77,500 & 390 & 7.3 & 382 & 397 & 3.9 & 142,200 \\
\hline 09406100 & 2007 & 67 & 48,500 & 337 & 2.5 & 331 & 342 & 2.9 & 122,900 \\
\hline 09406100 & 2008 & 74 & 53,700 & 342 & 3.2 & 336 & 348 & 3.1 & 125,200 \\
\hline 09406100 & 2009 & 68 & 49,200 & 329 & 2.3 & 324 & 335 & 2.7 & 120,300 \\
\hline 09406100 & 2010 & 112 & 81,100 & 377 & 7.1 & 370 & 385 & 3.8 & 137,600 \\
\hline 09408135 & 2005 & 713 & 516,300 & 553 & 2,005 & 470 & 646 & 45 & 201,700 \\
\hline 09408135 & 2006 & 138 & 99,900 & 374 & 151 & 350 & 399 & 13 & 136,600 \\
\hline 09408135 & 2007 & 82 & 59,400 & 330 & 101 & 310 & 351 & 10 & 120,400 \\
\hline 09408135 & 2008 & 94 & 68,000 & 338 & 103 & 318 & 359 & 10 & 123,700 \\
\hline 09408135 & 2009 & 83 & 60,100 & 333 & 102 & 313 & 354 & 10 & 121,500 \\
\hline 09408135 & 2010 & 146 & 105,300 & 377 & 159 & 352 & 403 & 13 & 137,500 \\
\hline 09408150 & 1992 & 149 & 108,100 & 312 & 145 & 288 & 338 & 13 & 114,300 \\
\hline 09408150 & 1993 & 469 & 339,300 & 208 & 130 & 185 & 233 & 12 & 75,800 \\
\hline 09408150 & 1994 & 157 & 113,300 & 492 & 302 & 457 & 529 & 18 & 179,600 \\
\hline 09408150 & 1995 & 342 & 247,700 & 620 & 714 & 567 & 677 & 28 & 226,400 \\
\hline 09408150 & 1996 & 127 & 92,100 & 432 & 160 & 405 & 459 & 14 & 157,900 \\
\hline 09408150 & 1997 & 152 & 109,900 & 448 & 143 & 422 & 474 & 13 & 163,500 \\
\hline 09408150 & 1998 & 288 & 208,500 & 586 & 447 & 543 & 631 & 22 & 214,000 \\
\hline 09408150 & 1999 & 147 & 106,600 & 485 & 161 & 458 & 513 & 14 & 177,000 \\
\hline 09408150 & 2000 & 122 & 88,300 & 412 & 88 & 391 & 433 & 11 & 150,700 \\
\hline
\end{tabular}


Appendix 1. Mean daily and annual streamflow and dissolved-solids load at selected sites in the Virgin River Basin, Utah, Arizona, and Nevada.-Continued

[Annual mean streamflow, the arithmetic mean for the individual daily mean discharges for the year. Annual runoff indicates the total quantity of water in runoff for a drainage area for the year and is calculated by multiplying the annual mean streamflow at the gaging station by 1.983471 to convert from cubic feet per second to acre-feet per day and by the number of days in the year. NA, not applicable]

\begin{tabular}{|c|c|c|c|c|c|c|c|c|c|}
\hline \multirow[b]{2}{*}{$\begin{array}{l}\text { Site number } \\
\text { (U.S. Geological } \\
\text { Survey down- } \\
\text { stream order } \\
\text { number) }\end{array}$} & \multirow[b]{2}{*}{ Water year } & \multirow[b]{2}{*}{$\begin{array}{l}\text { Annual mean } \\
\text { streamflow } \\
\text { (cubic feet per } \\
\text { second) }\end{array}$} & \multirow[b]{2}{*}{$\begin{array}{c}\text { Annual } \\
\text { runoff } \\
\text { (acre-feet per } \\
\text { year) }\end{array}$} & \multicolumn{6}{|c|}{ Dissolved-solids load } \\
\hline & & & & $\begin{array}{c}\text { Estimated } \\
\text { annual mean } \\
\text { load } \\
\text { (tons per day) }\end{array}$ & $\begin{array}{c}\text { Variance of } \\
\text { estimated } \\
\text { annual mean } \\
\text { load } \\
\text { (tons per day) }\end{array}$ & $\begin{array}{l}\text { Lower 95-percent } \\
\text { confidence } \\
\text { limit of } \\
\text { estimated annual } \\
\text { mean load } \\
\text { (tons per day) }\end{array}$ & $\begin{array}{c}\text { Upper 95-percent } \\
\text { confidence } \\
\text { limit of } \\
\text { estimated annual } \\
\text { mean load } \\
\text { (tons per day) }\end{array}$ & $\begin{array}{c}\text { Standard error } \\
\text { of prediction for } \\
\text { estimated annual } \\
\text { mean load } \\
\text { (tons per day) }\end{array}$ & $\begin{array}{c}\text { Estimated } \\
\text { annual load } \\
\text { (tons per year) }\end{array}$ \\
\hline 09408150 & 2001 & 130 & 94,300 & 424 & 93 & 403 & 446 & 11 & 154,800 \\
\hline 09408150 & 2002 & 72 & 51,900 & 304 & 59 & 287 & 321 & 8.6 & 110,900 \\
\hline 09408150 & 2003 & 72 & 52,000 & 294 & 62 & 277 & 311 & 8.7 & 107,200 \\
\hline 09408150 & 2004 & 82 & 59,800 & 327 & 76 & 309 & 346 & 9.7 & 119,700 \\
\hline 09408150 & 2005 & 715 & 517,400 & 628 & 2,224 & 540 & 727 & 48 & 229,400 \\
\hline 09408150 & 2006 & 169 & 122,400 & 459 & 215 & 428 & 490 & 16 & 167,400 \\
\hline 09408150 & 2007 & 91 & 66,000 & 339 & 124 & 316 & 363 & 12 & 123,700 \\
\hline 09408150 & 2008 & 103 & 75,000 & 352 & 156 & 326 & 378 & 13 & 128,700 \\
\hline 09408150 & 2009 & 92 & 66,900 & 341 & 171 & 315 & 369 & 14 & 124,500 \\
\hline 09408150 & 2010 & 148 & 107,200 & 403 & 294 & 369 & 440 & 18 & 147,200 \\
\hline 09408195 & 2002 & 0.2 & 132 & 0.9 & 0 & 0.5 & 1.5 & 0.2 & 336 \\
\hline 09408195 & 2003 & 6.4 & 4,660 & 25 & 35 & 15 & 41 & 6.6 & 9,260 \\
\hline 09408195 & 2004 & 2.8 & 2,040 & 11 & 5.5 & 6.7 & 18 & 2.8 & 4,120 \\
\hline 09408195 & 2005 & 6.9 & 4,970 & 21 & 17 & 13 & 31 & 4.7 & 7,510 \\
\hline 09408195 & 2006 & 2.2 & 1,570 & 9.1 & 3.0 & 5.7 & 14 & 2.1 & 3,320 \\
\hline 09408195 & 2007 & 0.8 & 549 & 3.6 & 0.3 & 2.4 & 5.2 & 0.7 & 1,300 \\
\hline 09408195 & 2008 & 8.6 & 6,220 & 34 & 7.2 & 28 & 40 & 2.9 & 12,300 \\
\hline 09408195 & 2009 & 0.1 & 62 & 0 & 0 & 0.3 & 0.7 & 0.1 & 161 \\
\hline 09408195 & 2010 & 0.7 & 514 & 3.1 & 0.2 & 2.0 & 4.7 & 0.7 & 1,140 \\
\hline 09413000 & 1992 & 8.2 & 5,900 & 21 & 0.4 & 20 & 22 & 0.7 & 7,680 \\
\hline 09413000 & 1993 & 56 & 40,500 & 71 & 9.3 & 65 & 77 & 3.2 & 25,900 \\
\hline 09413000 & 1994 & 7.4 & 5,300 & 26 & 0.4 & 25 & 28 & 0.7 & 9,620 \\
\hline 09413000 & 1995 & 53 & 38,100 & 66 & 6.1 & 61 & 71 & 2.6 & 24,200 \\
\hline 09413000 & 1996 & 5.3 & 3,900 & 23 & 0.3 & 22 & 24 & 0.6 & 8,510 \\
\hline 09413000 & 1997 & 7.6 & 5,500 & 28 & 0.3 & 27 & 30 & 0.7 & 10,300 \\
\hline 09413000 & 1998 & 36 & 26,100 & 69 & 4.5 & 65 & 74 & 2.3 & 25,400 \\
\hline 09413000 & 1999 & 12 & 8,500 & 44 & 0.9 & 42 & 47 & 1.1 & 16,200 \\
\hline 09413000 & 2000 & 2.9 & 2,100 & 16 & 0.1 & 16 & 17 & 0.3 & 5,920 \\
\hline 09413000 & 2001 & 4.7 & 3,400 & 24 & 0.2 & 23 & 25 & 0.5 & 8,810 \\
\hline 09413000 & 2002 & 2.3 & 1,600 & 14 & 0.1 & 14 & 15 & 0.3 & 5,210 \\
\hline 09413000 & 2003 & 2.2 & 1,600 & 14 & 0.1 & 13 & 15 & 0.4 & 5,150 \\
\hline 09413000 & 2004 & 2.8 & 2,100 & 17 & 0.1 & 17 & 18 & 0.4 & 6,340 \\
\hline 09413000 & 2005 & 117 & 84,800 & 162 & 76 & 146 & 181 & 8.9 & 59,300 \\
\hline 09413000 & 2006 & 19 & 13,800 & 73 & 3.8 & 69 & 77 & 2.1 & 26,700 \\
\hline 09413000 & 2007 & 5.4 & 3,900 & 30 & 0.5 & 29 & 32 & 0.8 & 11,000 \\
\hline 09413000 & 2008 & 9.2 & 6,700 & 49 & 1.8 & 46 & 52 & 1.4 & 18,000 \\
\hline 09413000 & 2009 & 15 & 10,900 & 63 & 4.2 & 58 & 67 & 2.2 & 22,800 \\
\hline 09413000 & 2010 & 10 & 7,200 & 52 & 2.6 & 49 & 56 & 1.7 & 19,000 \\
\hline 09413200 & 1992 & 145 & 105,000 & 563 & 209 & 531 & 595 & 16 & 205,900 \\
\hline 09413200 & 1993 & 511 & 369,600 & 1,179 & 2,682 & 1,076 & 1,290 & 55 & 430,500 \\
\hline
\end{tabular}


Appendix 1. Mean daily and annual streamflow and dissolved-solids load at selected sites in the Virgin River Basin, Utah, Arizona, and Nevada.-Continued

[Annual mean streamflow, the arithmetic mean for the individual daily mean discharges for the year. Annual runoff indicates the total quantity of water in runoff for a drainage area for the year and is calculated by multiplying the annual mean streamflow at the gaging station by 1.983471 to convert from cubic feet per second to acre-feet per day and by the number of days in the year. NA, not applicable]

\begin{tabular}{|c|c|c|c|c|c|c|c|c|c|}
\hline \multirow[b]{2}{*}{$\begin{array}{l}\text { Site number } \\
\text { (U.S. Geological } \\
\text { Survey down- } \\
\text { stream order } \\
\text { number) }\end{array}$} & \multirow[b]{2}{*}{ Water year } & \multirow[b]{2}{*}{$\begin{array}{l}\text { Annual mean } \\
\text { streamflow } \\
\text { (cubic feet per } \\
\text { second) }\end{array}$} & \multirow[b]{2}{*}{$\begin{array}{c}\text { Annual } \\
\text { runoff } \\
\text { (acre-feet per } \\
\text { year) }\end{array}$} & \multicolumn{6}{|c|}{ Dissolved-solids load } \\
\hline & & & & $\begin{array}{c}\text { Estimated } \\
\text { annual mean } \\
\text { load } \\
\text { (tons per day) }\end{array}$ & $\begin{array}{c}\text { Variance of } \\
\text { estimated } \\
\text { annual mean } \\
\text { load } \\
\text { (tons per day) }\end{array}$ & $\begin{array}{l}\text { Lower 95-percent } \\
\text { confidence } \\
\text { limit of } \\
\text { estimated annual } \\
\text { mean load } \\
\text { (tons per day) }\end{array}$ & $\begin{array}{l}\text { Upper 95-percent } \\
\text { confidence } \\
\text { limit of } \\
\text { estimated annual } \\
\text { mean load } \\
\text { (tons per day) }\end{array}$ & $\begin{array}{c}\text { Standard error } \\
\text { of prediction for } \\
\text { estimated annual } \\
\text { mean load } \\
\text { (tons per day) }\end{array}$ & $\begin{array}{c}\text { Estimated } \\
\text { annual load } \\
\text { (tons per year) }\end{array}$ \\
\hline 09413200 & 1994 & 148 & 106,800 & 597 & 231 & 564 & 631 & 17 & 218,000 \\
\hline 09413200 & 1995 & 401 & 290,100 & 1,045 & 1,641 & 963 & 1,132 & 43 & 381,500 \\
\hline 09413200 & 1996 & 115 & 83,600 & 497 & 180 & 468 & 527 & 15 & 181,900 \\
\hline 09413200 & 1997 & 151 & 109,200 & 583 & 228 & 550 & 617 & 17 & 212,700 \\
\hline 09413200 & 1998 & 331 & 239,300 & 937 & 1,137 & 868 & 1,009 & 36 & 341,900 \\
\hline 09413200 & 1999 & 154 & 111,300 & 623 & 250 & 589 & 659 & 18 & 227,500 \\
\hline 09413200 & 2000 & 108 & 78,500 & 478 & 157 & 451 & 506 & 14 & 174,800 \\
\hline 09413200 & 2001 & 121 & 87,800 & 515 & 164 & 487 & 544 & 15 & 188,000 \\
\hline 09413200 & 2002 & 58 & 42,000 & 329 & 110 & 307 & 352 & 11 & 120,100 \\
\hline 09413200 & 2003 & 62 & 44,700 & 330 & 102 & 309 & 352 & 11 & 120,400 \\
\hline 09413200 & 2004 & 61 & 43,900 & 331 & 113 & 309 & 354 & 12 & 121,200 \\
\hline 09413200 & 2005 & 759 & 549,100 & 1,480 & 6,286 & 1,324 & 1,648 & 83 & 540,100 \\
\hline 09413200 & 2006 & 176 & 127,300 & 653 & 284 & 617 & 691 & 19 & 238,300 \\
\hline 09413200 & 2007 & 89 & 64,100 & 432 & 125 & 408 & 457 & 13 & 157,700 \\
\hline 09413200 & 2008 & 104 & 75,200 & 475 & 145 & 449 & 502 & 14 & 173,800 \\
\hline 09413200 & 2009 & 99 & 71,300 & 464 & 136 & 439 & 490 & 13 & 169,400 \\
\hline 09413200 & 2010 & 160 & 115,700 & 593 & 230 & 560 & 627 & 17 & 216,300 \\
\hline 09413500 & 1992 & 144 & 104,700 & 544 & 261 & 512 & 578 & 17 & 199,300 \\
\hline 09413500 & 1993 & 472 & 341,400 & 966 & 885 & 907 & 1,027 & 31 & 352,400 \\
\hline 09413500 & 1994 & 154 & 111,600 & 603 & 136 & 579 & 628 & 13 & 220,100 \\
\hline 09413500 & 1995 & 402 & 291,000 & 920 & 403 & 879 & 962 & 21 & 335,700 \\
\hline 09413500 & 1996 & 113 & 82,300 & 477 & 53 & 461 & 493 & 8 & 174,500 \\
\hline 09413500 & 1997 & 170 & 122,900 & 590 & 80 & 570 & 609 & 10 & 215,200 \\
\hline 09413500 & 1998 & 330 & 238,700 & 825 & 291 & 790 & 861 & 18 & 301,000 \\
\hline 09413500 & 1999 & 155 & 111,900 & 605 & 111 & 583 & 627 & 11 & 220,700 \\
\hline 09413500 & 2000 & 109 & 79,300 & 468 & 61 & 451 & 485 & 9 & 171,200 \\
\hline 09413500 & 2001 & 129 & 93,500 & 524 & 85 & 505 & 544 & 10 & 191,300 \\
\hline 09413500 & 2002 & 62 & 44,600 & 327 & 33 & 315 & 340 & 6 & 119,500 \\
\hline 09413500 & 2003 & 75 & 54,200 & 354 & 34 & 341 & 366 & 7 & 129,000 \\
\hline 09413500 & 2004 & 75 & 54,100 & 375 & 36 & 362 & 388 & 7 & 137,200 \\
\hline 09413500 & 2005 & 735 & 532,000 & 1,133 & 1,685 & 1,053 & 1,218 & 42 & 413,600 \\
\hline 09413500 & 2006 & 171 & 123,600 & 630 & 107 & 608 & 652 & 11 & 229,800 \\
\hline 09413500 & 2007 & 97 & 70,500 & 459 & 56 & 443 & 475 & 8 & 167,600 \\
\hline 09413500 & 2008 & 107 & 77,400 & 501 & 86 & 482 & 521 & 10 & 183,400 \\
\hline 09413500 & 2009 & 100 & 72,100 & 496 & 122 & 473 & 519 & 12 & 180,900 \\
\hline 09413500 & 2010 & 161 & 116,200 & 630 & 297 & 596 & 666 & 18 & 229,900 \\
\hline 09413700 & 1999 & 129 & 93,000 & 502 & 443 & 461 & 545 & 21 & 183,200 \\
\hline 09413700 & 2000 & 88 & 63,800 & 379 & 123 & 357 & 402 & 12 & 138,600 \\
\hline 09413700 & 2001 & 95 & 68,400 & 413 & 102 & 393 & 434 & 11 & 150,800 \\
\hline 09413700 & 2002 & 46 & 33,400 & 255 & 47 & 241 & 270 & 7.2 & 93,200 \\
\hline 09413700 & 2003 & 55 & 40,100 & 293 & 72 & 276 & 311 & 8.9 & 107,000 \\
\hline
\end{tabular}


Appendix 1. Mean daily and annual streamflow and dissolved-solids load at selected sites in the Virgin River Basin, Utah, Arizona, and Nevada.-Continued

[Annual mean streamflow, the arithmetic mean for the individual daily mean discharges for the year. Annual runoff indicates the total quantity of water in runoff for a drainage area for the year and is calculated by multiplying the annual mean streamflow at the gaging station by 1.983471 to convert from cubic feet per second to acre-feet per day and by the number of days in the year. NA, not applicable]

\begin{tabular}{|c|c|c|c|c|c|c|c|c|c|}
\hline \multirow[b]{2}{*}{$\begin{array}{l}\text { Site number } \\
\text { (U.S. Geological } \\
\text { Survey down- } \\
\text { stream order } \\
\text { number) }\end{array}$} & \multirow[b]{2}{*}{ Water year } & \multirow[b]{2}{*}{$\begin{array}{l}\text { Annual mean } \\
\text { streamflow } \\
\text { (cubic feet per } \\
\text { second) }\end{array}$} & \multirow[b]{2}{*}{$\begin{array}{c}\text { Annual } \\
\text { runoff } \\
\text { (acre-feet per } \\
\text { year) }\end{array}$} & \multicolumn{6}{|c|}{ Dissolved-solids load } \\
\hline & & & & $\begin{array}{c}\text { Estimated } \\
\text { annual mean } \\
\text { load } \\
\text { (tons per day) }\end{array}$ & $\begin{array}{c}\text { Variance of } \\
\text { estimated } \\
\text { annual mean } \\
\text { load } \\
\text { (tons per day) }\end{array}$ & $\begin{array}{l}\text { Lower } 95 \text {-percent } \\
\text { confidence } \\
\text { limit of } \\
\text { estimated annual } \\
\text { mean load } \\
\text { (tons per day) }\end{array}$ & $\begin{array}{l}\text { Upper 95-percent } \\
\text { confidence } \\
\text { limit of } \\
\text { estimated annual } \\
\text { mean load } \\
\text { (tons per day) }\end{array}$ & $\begin{array}{c}\text { Standard error } \\
\text { of prediction for } \\
\text { estimated annual } \\
\text { mean load } \\
\text { (tons per day) }\end{array}$ & $\begin{array}{c}\text { Estimated } \\
\text { annual load } \\
\text { (tons per year) }\end{array}$ \\
\hline 09413700 & 2004 & 56 & 40,400 & 299 & 88 & 280 & 318 & 9.7 & 109,300 \\
\hline 09413700 & 2005 & 639 & 462,300 & 1,107 & 4,208 & 985 & 1,241 & 66 & 404,200 \\
\hline 09413700 & 2006 & 140 & 101,100 & 551 & 328 & 516 & 589 & 19 & 201,200 \\
\hline 09413700 & 2007 & 68 & 49,300 & 354 & 106 & 333 & 375 & 11 & 129,100 \\
\hline 09413700 & 2008 & 79 & 57,000 & 382 & 99 & 362 & 402 & 10 & 139,700 \\
\hline 09413700 & 2009 & 72 & 52,200 & 364 & 96 & 345 & 385 & 10 & 132,900 \\
\hline 09413700 & 2010 & 145 & 105,200 & 526 & 367 & 488 & 565 & 20 & 191,900 \\
\hline 09414900 & 2006 & 4.6 & 3,300 & 1.4 & -2.3 & NA & NA & NA & 497 \\
\hline 09414900 & 2007 & 3.5 & 2,500 & 2.0 & -4.1 & NA & NA & NA & 722 \\
\hline 09414900 & 2008 & 2.3 & 1,700 & 1.9 & -3.4 & NA & NA & NA & 705 \\
\hline 09414900 & 2009 & 2.8 & 2,000 & 2.8 & 0 & 2.7 & 2.9 & 0.1 & 1,010 \\
\hline 09414900 & 2010 & 3.7 & 2,700 & 3.8 & 0 & 3.8 & 3.9 & 0 & 1,390 \\
\hline 09415000 & 1992 & 191 & 138,400 & 874 & 359 & 836 & 912 & 19 & 319,800 \\
\hline 09415000 & 1993 & 594 & 430,100 & 1,362 & 3,008 & 1,257 & 1,474 & 55 & 497,300 \\
\hline 09415000 & 1994 & 183 & 132,200 & 872 & 155 & 847 & 898 & 13 & 318,300 \\
\hline 09415000 & 1995 & 493 & 356,600 & 1,270 & 1,095 & 1,206 & 1,338 & 34 & 463,700 \\
\hline 09415000 & 1996 & 164 & 118,800 & 794 & 76 & 775 & 812 & 9.4 & 290,400 \\
\hline 09415000 & 1997 & 211 & 152,700 & 881 & 105 & 859 & 903 & 11 & 321,400 \\
\hline 09415000 & 1998 & 378 & 273,900 & 1,193 & 533 & 1,148 & 1,241 & 24 & 435,600 \\
\hline 09415000 & 1999 & 192 & 139,000 & 885 & 125 & 863 & 909 & 12 & 323,200 \\
\hline 09415000 & 2000 & 147 & 106,900 & 734 & 80 & 716 & 753 & 9.5 & 268,800 \\
\hline 09415000 & 2001 & 149 & 108,100 & 746 & 88 & 727 & 766 & 10 & 272,300 \\
\hline 09415000 & 2002 & 103 & 74,300 & 587 & 60 & 571 & 603 & 8.2 & 214,100 \\
\hline 09415000 & 2003 & 116 & 84,200 & 620 & 62 & 604 & 637 & 8.4 & 226,400 \\
\hline 09415000 & 2004 & 113 & 81,900 & 624 & 59 & 608 & 640 & 8.2 & 228,200 \\
\hline 09415000 & 2005 & 825 & 597,100 & 1,504 & 5,700 & 1,361 & 1,658 & 76 & 548,800 \\
\hline 09415000 & 2006 & 233 & 168,600 & 977 & 205 & 948 & 1,007 & 15 & 356,800 \\
\hline 09415000 & 2007 & 133 & 96,500 & 711 & 75 & 693 & 729 & 9.2 & 259,500 \\
\hline 09415000 & 2008 & 158 & 114,800 & 795 & 125 & 772 & 818 & 12 & 291,000 \\
\hline 09415000 & 2009 & 125 & 90,600 & 701 & 129 & 679 & 725 & 12 & 256,000 \\
\hline 09415000 & 2010 & 207 & 150,100 & 912 & 368 & 875 & 952 & 20 & 333,100 \\
\hline 09415250 & 2007 & 96 & 69,700 & 804 & 27,270 & 528 & 1,173 & 165 & 293,300 \\
\hline 09415250 & 2008 & 121 & 87,600 & 717 & 2,511 & 624 & 820 & 50 & 262,400 \\
\hline 09415250 & 2009 & 108 & 78,200 & 601 & 326 & 566 & 637 & 18 & 219,300 \\
\hline 09415250 & 2010 & 169 & 122,400 & 715 & 321 & 680 & 751 & 18 & 260,900 \\
\hline
\end{tabular}






\section{䞤}

